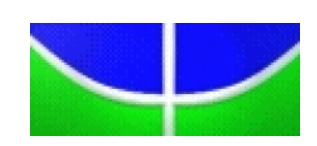

UNIVERSIDADE DE BRASÍLIA - UnB

INSTITUTO DE LETRAS - IL

DEPARTAMENTO DE LÍNGUAS ESTRANGEIRAS E TRADUÇÃO - LET PROGRAMA DE PÓS-GRADUAÇÃO EM ESTUDOS DE TRADUÇÃO POSTRAD

\title{
QUESTÕES DE TRADUÇÃO DE JORNALISMO EM QUADRINHOS: ANÁLISE CRÍTICA DE NOTAS SOBRE GAZA
}

\section{GABRIELA CRISTINA TEIXEIRA NETTO DO NASCIMENTO}

DISSERTAÇÃO DE MESTRADO EM ESTUDOS DA TRADUÇÃO 


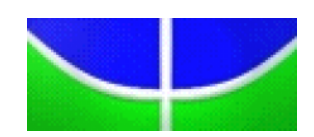

UNIVERSIDADE DE BRASÍLIA - UnB INSTITUTO DE LETRAS - IL

DEPARTAMENTO DE LÍNGUAS ESTRANGEIRAS E TRADUÇÃO - LET PROGRAMA DE PÓS-GRADUAÇÃO EM ESTUDOS DE TRADUÇÃO POSTRAD

QUESTÕES DE TRADUÇÃO DE JORNALISMO EM QUADRINHOS: ANÁLISE CRÍTICA DE NOTAS SOBRE GAZA

GABRIELA CRISTINA TEIXEIRA NETTO DO NASCIMENTO ORIENTADOR: PROF. DR. MARK DAVID RIDD DISSERTAÇÃO DE MESTRADO EM ESTUDOS DA TRADUÇÃO

BRASÍLIA/DF MARÇO/2016

UNIVERSIDADE DE BRASÍLIA - UNB INSTITUTO DE LETRAS - IL DEPARTAMENTO DE LÍNGUAS ESTRANGEIRAS - LET 
Ficha catalográfica elaborada automaticamente, com os dados fornecidos pelo(a) autor(a)

N $N 244 \mathrm{q}$

Nascimento, Gabriela Cristina Teixeira Netto do

Questōes de tradução de jornalismo em quadrinhos: análise crítica de Notas sobre Gaza / Gabriela Cristina Teixeira Netto do Nascimento; orientador Mark David Ridd. -- Brasilia, 2016.

$120 \mathrm{p}$.

Dissertação (Mestrado - Mestrado em Estudos de Tradução) -- Universidade de Brasilia, 2016.

1. tradução de quadrinhos. 2. textos sensiveis. 3 . análise crítica de tradução. 4. conflito Israel

Palestina. I. Ridd, Mark David, orient. II. Título. 
PROGRAMA DE PÓS-GRADUAÇÃo EM ESTUDOS DE TRADUÇÃO POSTRAD

QUESTÕES DE TRADUÇÃO DE JORNALISMO EM QUADRINHOS: ANÁLISE CRÍTICA DE NOTAS SOBRE GAZA

\section{GABRIELA CRISTINA TEIXEIRA NETTO DO NASCIMENTO}

DISSERTAÇÃO DE MESTRADO SUBMETIDA AO PROGRAMA DE PÓS-GRADUAÇÃ̃O EM ESTUDOS DA TRADUÇÃO DA UNIVERSIDADE DE BRASÍLIA - UNB, COMO PARTE DOS REQUISITOS NECESSÁRIOS PARA A OBTENÇÃO DO TÍTULO DE MESTRE EM ESTUDOS DA TRADUÇÃO.

APROVADA POR:

Prof. Dr. Mark David Ridd, UnB (orientador)

Prof. Dr. Paulo Ramos, UNIFESP (examinador externo)

Prof. a Dr. ${ }^{\text {a }}$ Soraya Ferreira Alves, UnB (examinadora interna)

Prof. ${ }^{a}$ Dr. ${ }^{a}$ Alice Maria Ferreira de Araújo, UnB (suplente) 


\section{AGRADECIMENTOS}

Agradeço ao Pai das Luzes que iluminou o meu caminho e minhas noites madrugada adentro.

Sou grata aos meus pais, Robson e Lúcia, pelo apoio, compreensão carinho constante nestes dois anos de estudo. À minha irmã, Rebeca, que sempre esteve ao meu lado.

Ao meu orientador, Mark, que com paciência e sabedoria me ajudou com esta pesquisa.

À Germana, por todas as dúvidas sanadas sobre o mestrado e o incentivo constante à pesquisa, uma mãe acadêmica que me colocou sob suas asas.

Aos professores do POSTRAD, pelo conhecimento partilhado e crescimento acadêmico, em especial à Alessandra, Alice, Émilie, Mark, Soraya e Germana.

Aos colegas e amigos de mestrado, pela companhia, cafés e conversas sobre tradução e sobre a vida.

À CAPES pelo incentivo e fomento à pesquisa.

Ao Érico e ao Augusto, que me ensinaram mais sobre o jornalismo em quadrinhos e mostraram como esse mundo é riquíssimo.

À Cláudia, taurina, professora, tradutora e amiga maravilhosa que foi um braço direito para mim em várias áreas da minha vida. Obrigada por tudo!

Às queridas Jakeline e Lorena, pelas noites mal dormidas, os compartilhamentos de livros e teorias, além de apoio emocional, espiritual e físico durante essa jornada.

À Agnes, Rodrigo e Patrícia, caríssimos e indispensáveis na minha vida como mestranda.

À Ana Clara, amiga de todos os cafés e de todas as horas. 
À Bernadete, por ser o ouvido mais atento às minhas indagações e a voz da razão que eu precisava ouvir.

À CAPES, pelo incentivo à pesquisa nestes dois anos.

E a todas as pessoas importantes que contribuíram e fizeram a diferença na minha vida, minha eterna gratidão a todos vocês. 
"Translation is not a matter of words only: it is a matter of making intelligible a whole culture." Anthony Burgess 


\section{RESUMO}

O objetivo desta pesquisa é contribuir para a reflexão no campo Estudos de Tradução em relação à análise crítica da tradução de quadrinhos. Textos multimodais, como quadrinhos, compreendem vários aspectos importantes, tais como a relação entre imagem e texto, o desenvolvimento da narrativa e da arte sequencial, a presença de fatores culturais, históricos e políticos. Dentro deste gênero, o jornalismo em história em quadrinhos vem ganhando espaço como um novo subgênero. A fim de proporcionar uma análise abrangente, escolheu-se o livro Notas sobre Gaza, de Joe Sacco, trabalho relevante nas esferas jornalística, literária e linguística. Algumas características sobressaem neste tipo de reportagem, isto é, a sensibilidade linguística, a alteridade, a mistura de observações objetivas e pessoais, como também o estilo do escritor. A análise crítica da tradução visa pontuar a recriação dos efeitos e mecanismos do original à luz do funcionalismo (REISS e VERMEER, 2013; NORD, 2005), da narrativa e arte sequencial (CAGNIN, 2014; CHINEN, 2015; EISNER, 2012; MCCLOUD, 2004; RAMOS, 2011, 2012a, 2012b) da tradução de histórias em quadrinhos (ZANETTIN, 2008), do elemento semiótico nos quadrinhos (CELOTTI, 2008; SANTAELLA, 2005), tradução e sensibilidade (SIMMS, 2006), e outros aspectos importantes relacionados com tradução e HQs.

Palavras-chave: tradução de quadrinhos; textos sensíveis; funcionalismo alemão; transcriação 


\begin{abstract}
The aim of this research is to enhance reflection in the field of Translation Studies regarding critical analysis of comics translation. Multimodal texts such as comics encompass several important aspects, e.g. the relation between image and text, narrative and sequential art development, and the presence of cultural, historical and political factors. Within this genre, comics journalism is gaining ground as a new subgenre. Footnotes in Gaza, by Joe Sacco, which is relevant in journalistic, literary, and linguistic terms, was chosen so as to offer a comprehensive analysis. Certain characteristics are to the fore in this type of news, i.e. linguistic sensitivity, otherness, a mixture of objective and personal standpoints, and the writer's style. These features are to be analysed to understand how the translation into Brazilian Portuguese, Notas sobre Gaza, has recreated the effects and mechanisms of the original in light of functionalism (REISS and VERMEER, 2013; NORD, 2005), narrative and sequential art (CAGNIN, 2014; CHINEN, 2015; EISNER, 2012; MCCLOUD, 2004; RAMOS, 2011, 2012a, 2012b) comics translation (ZANETTIN, 2008), semiotic features in comics (CELOTTI, 2008; SANTAELLA, 2005), translating sensitivity (SIMMS, 2006), and other significant aspects related to translation and comics.
\end{abstract}

Keywords: translation of comics, sensitive texts, German functionalism; transcriation 


\section{SUMÁRIO}

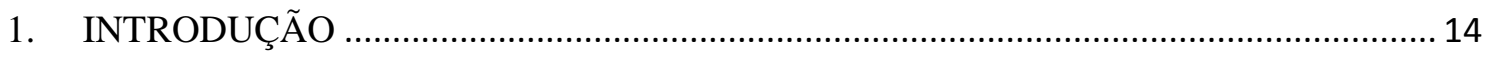

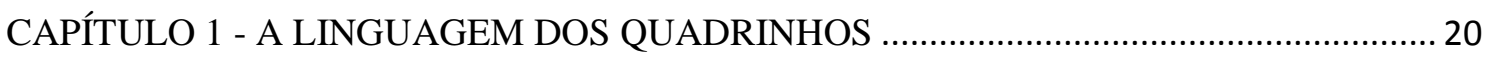

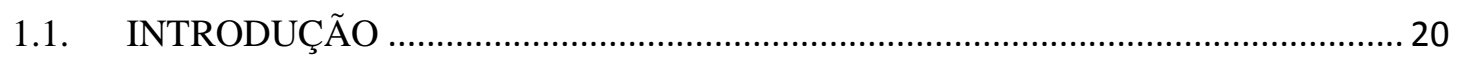

1.2. A CONSTITUIÇÃO DA HISTÓRIA EM QUADRINHOS .......................................... 21

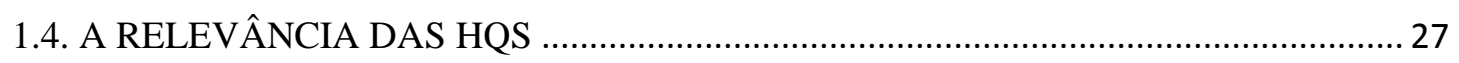

1.4.1. Nas escolas e nas universidades ...................................Erro! Indicador não definido.

1.5. SOBRE O JORNALISMO EM QUADRINHOS .......................................................... 31

1.6. A REPORTAGEM EM QUADRINHOS DE JOE SACCO: NOTAS SOBRE GAZA...... 33

1.6.1. Joe Sacco: o jornalista e cartunista de zonas de conflito ........................................... 33

1.6.2. O jornalismo em quadrinhos de Sacco ……............................................................ 35

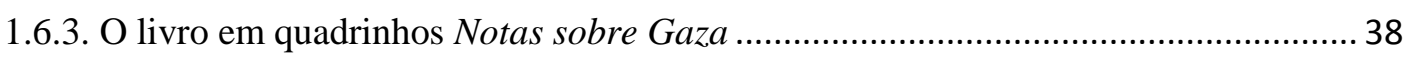

CAPÍTULO 2 - REFERENCIAL TEÓRICO E MÉTODO .......................................................... 40

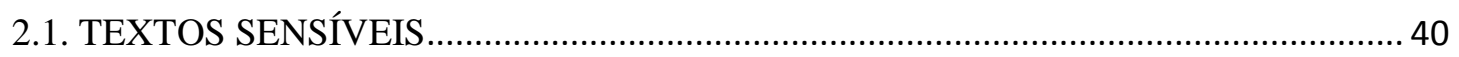

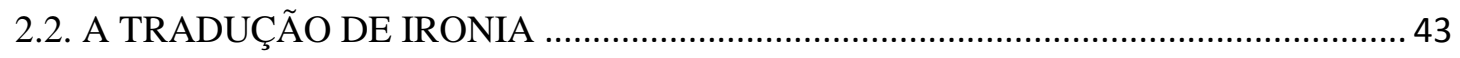

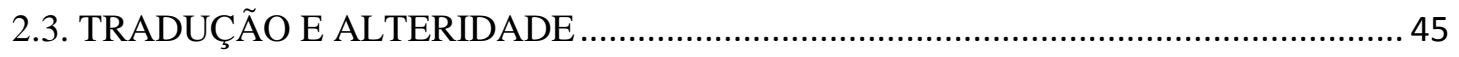

2.3.1. A alteridade na tradução de quadrinhos ................................................................... 46

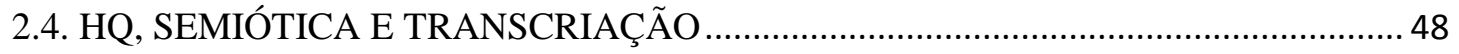

2.5. O FUNCIONALISMO ALEMÃO: TEORIA DO ESCOPO E TEORIA

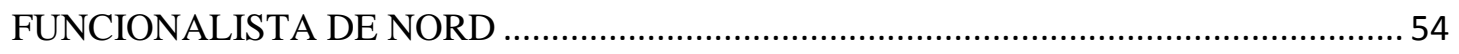

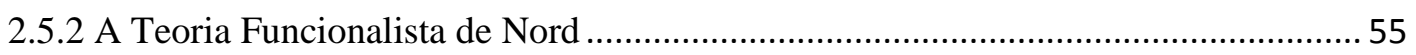

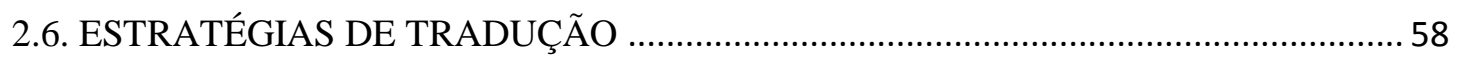

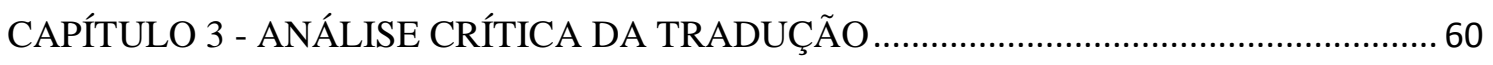

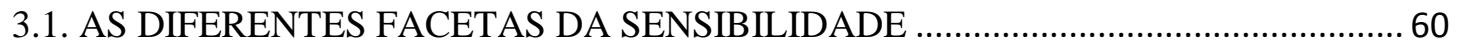

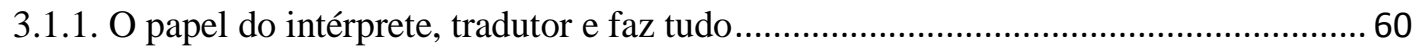

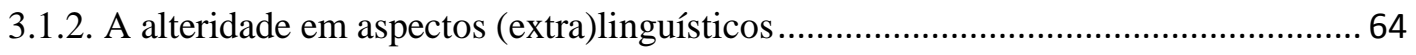

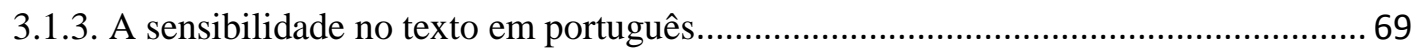

3.2. ANÁLISE DAS ESTRATÉGIAS DE TRADUÇÃO …………................................... 71

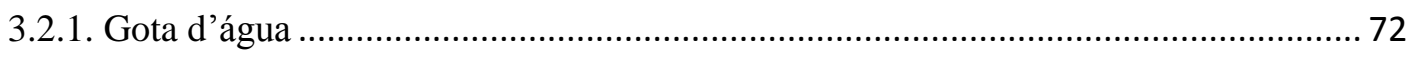

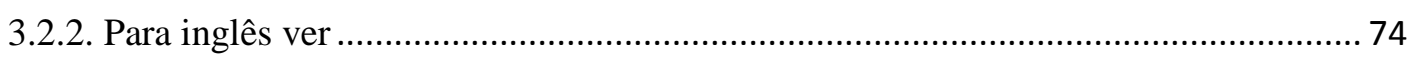

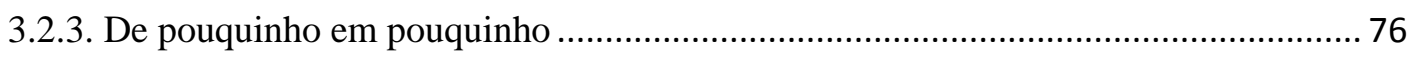




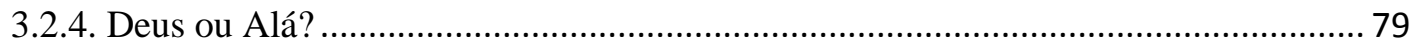

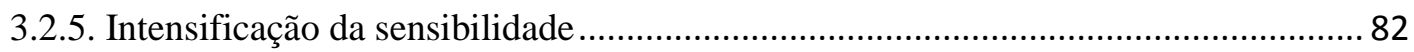

3.2.6. Estilo do autor em português..................................................................................... 91

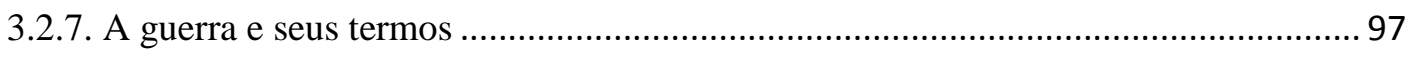

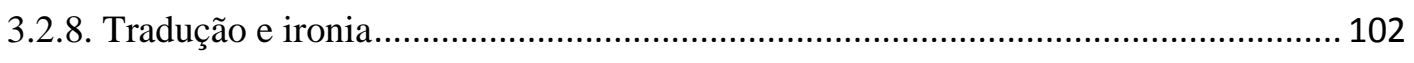

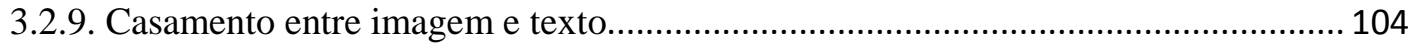

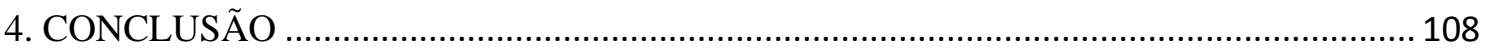

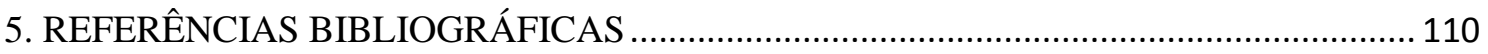

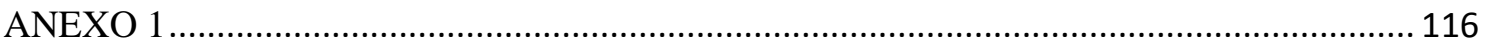

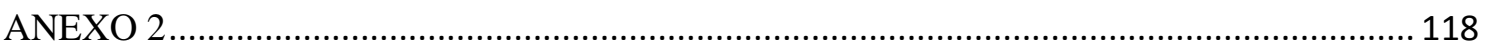




\section{LISTA DE FIGURAS}

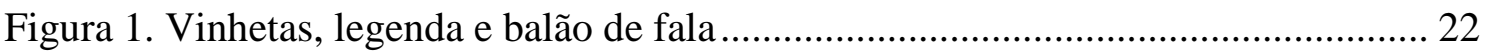

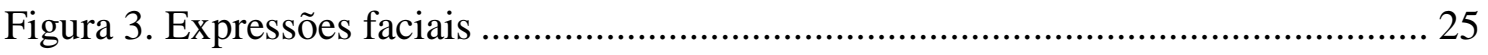

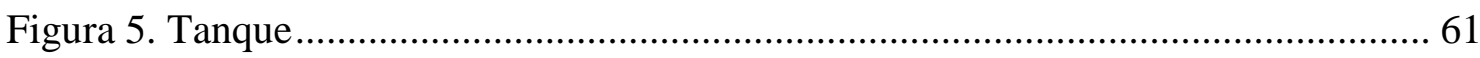

Figura 7. Inshallah, Salaam aleikum e Aleikum es-salaam ........................................ 67

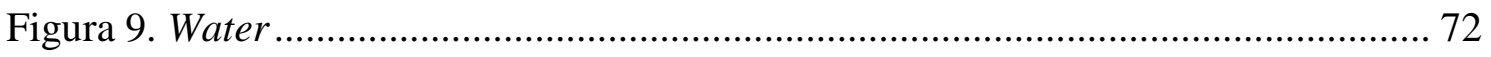

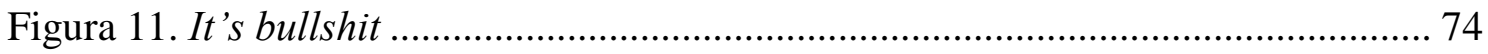

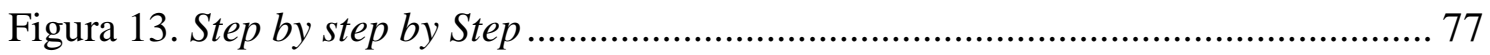

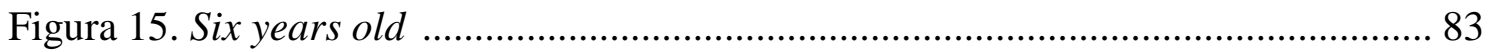

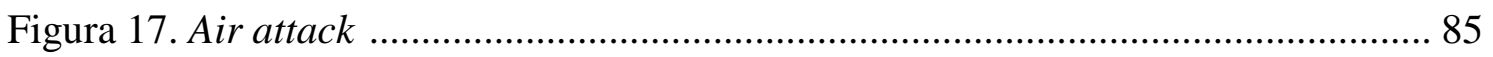

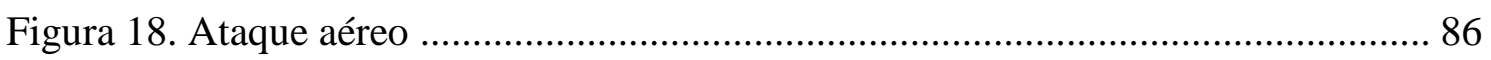

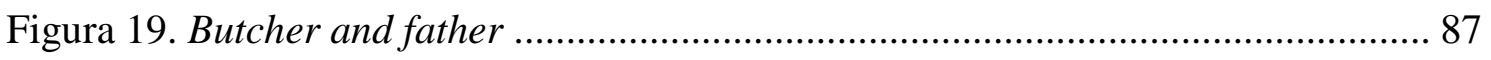

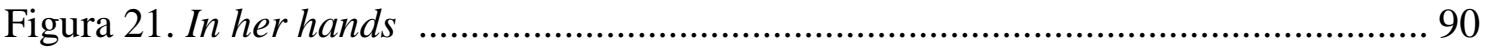

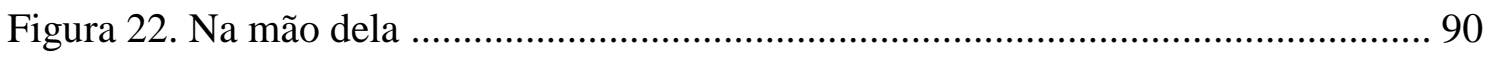

Figura 24. Lançar bombas, muitas bombas ................................................................ 92

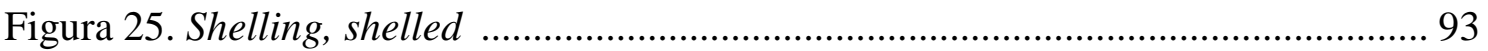

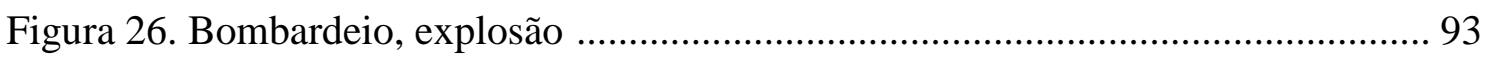

Figura 27. Demolished, demolishing, demolitions ...................................................... 96

Figura 28. Demolida, demoliam, demolições ............................................................ 96

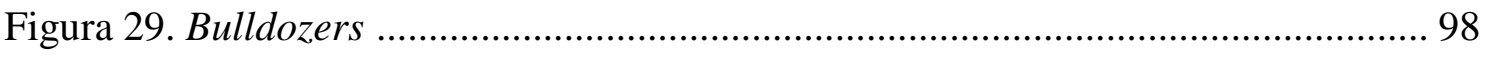

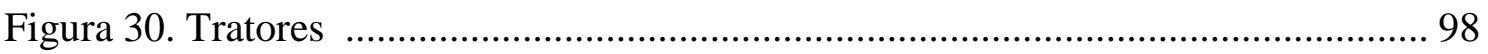

Figura 31. Enclaves, IDF and UNWRA (pronounced as one word) ........................... 99

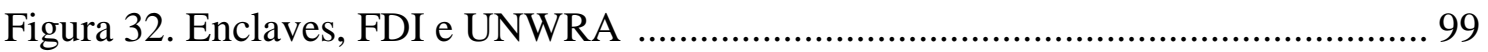




\section{INTRODUÇÃO}

As histórias em quadrinhos (HQs) foram se reformulando com o passar dos $\operatorname{anos}^{1}$. Há diversos tipos de narrativas quadrinísticas, como as tiras cômicas, as fotonovelas, os gibis, que apresentam uma gama de conteúdos para vários públicos. Por se tratar de um hipergênero ${ }^{2}$ que traz informações nos níveis verbal e visual, as HQs se diferem de outros tipos de textos.

Para os Estudos da Tradução, a tradução de HQs requer uma compreensão e interpretação da tradução interlingual, bem como da tradução semiótica. São pontos cruciais para o processo tradutório e análise crítica de tradução. Infere-se, portanto, que há a necessidade de estudos mais profundos sobre essa categoria da tradução, uma vez que a linguagem de HQs, fruto da conjunção de elementos verbovisuais, influencia na maneira como o texto será traduzido.

Este trabalho contribui para o debate sobre como os Estudos da Tradução necessitam de uma discussão teórica no âmbito da análise crítica da tradução de histórias em quadrinhos. Aspectos relevantes como a relação imagem e palavra, as restrições e limitações da linguagem de HQ, questões culturais, religiosas e políticas fazem com que os quadrinhos possam apresentar questões e desafios ao serem traduzidos. Além desses pontos, é necessário identificar e mapear possíveis estratégias que o tradutor desse gênero possa usar para que a leitura do texto traduzido seja funcional, adequada e recrie os mecanismos do texto de partida na língua de chegada.

Hoje, os estudos relacionados à tradução de histórias em quadrinhos tentam abarcar as características do discurso narrativo em forma de diálogo direto e recordatórios ou legendas, assim como outros aspectos inerentes à narrativa. Entretanto,

\footnotetext{
${ }^{1}$ De acordo com Padovani (2015, p.56) isso ocorreu "possivelmente devido às inovações na produção, que tem mais liberdade, e na divulgação" principalmente com os quadrinhos underground. Além disso, para Valério e Lopes (2015) as novas plataformas e narrativas agradam diferentes públicos e o mercado editorial busca atendê-los. http://www.jornalcomunicacao.ufpr.br/diversidades-narrativas-das-hqs-atraempublico-diferenciado/ Acesso online em 12 de agosto de 2015.

${ }^{2}$ Segundo Ramos (2012a, p.21) esse hipergênero "agrega vários gêneros que compartilham uma mesma linguagem em textos predominantemente narrativos".
} 
deixam-se de lado muitas outras questões pertinentes que estão intrinsecamente ligadas à forma e apresentação dos quadrinhos, especificamente o tipo de quadrinhos jornalísticos, bem como aos aspectos sensíveis presentes no texto multimodal, que necessitam de muito cuidado e atenção ao serem traduzidos visto que podem trazer fatores objetivos e subjetivos, tópicos relacionados a governos, componentes históricos e culturais que podem indicar diferentes níveis de tensão.

O presente trabalho tem como propósito abordar alguns aspectos da tradução de quadrinhos, levando em consideração os elementos jornalísticos, semióticos e linguísticos do texto que estão associados aos textos sensíveis. Pretende-se também verificar os mecanismos usados para a recriação do texto ${ }^{3}$ de chegada dentro de um gênero híbrido e específico que mescla elementos marcados e não-marcados.

A intenção deste estudo é analisar as escolhas linguístico-culturais feitas na tradução da obra de Joe Sacco, Notas sobre Gaza (2010), traduzida por Alexandre Boide para o português. Alguns trechos serão analisados com base em uma fundamentação teórica ${ }^{4}$ a fim de examinar soluções, propor alternativas que poderiam torná-las mais comunicativas e funcionais em língua portuguesa e identificar a intensificação ou atenuação da sensibilidade no texto como um todo. Para tanto, as seguintes perguntas de pesquisa foram estabelecidas: 1. Quais aspectos (extra)linguísticos demonstram a alteridade? 2. Que tipos de processos de tradução aumentam ou diminuem o impacto da sensibilidade no texto em português? 3. Quais estratégias de tradução permitem a transcriação do estilo do autor? 4. Como os vocabulários relacionados à guerra são traduzidos? 5. A HQ traduzida continua a dialogar de forma análoga com a imagem? 6. Como a ironia é recriada no texto em português?

Este estudo poderia contribuir para a observação da tradução de textos sensíveis, tanto no aspecto de direitos humanos como no contexto de guerra. A sensibilidade pode estar presente em um texto devido ao tema, público-leitor e gênero. No jornalismo em quadrinhos, posições políticas, determinadas tradições e práticas culturais são retratadas

\footnotetext{
${ }^{3}$ Neste caso, o texto de chegada é a composição completa da linguagem, a veiculação da mensagem, bem como as representações imagéticas e verbais.

${ }^{4}$ Com base nas teorias da tradução, como o funcionalismo e a tradução de textos sensíveis, bem como noções aplicadas à tradução de HQs.
} 
na imagem e no texto, evidenciando as diferenças entre os sistemas linguístico-culturais envolvidos na tradução. Além disso, os propósitos dos textos de partida e de chegada variam de acordo com o público, o cliente e o contexto no qual a obra está inserida. Sendo assim, uma análise mais profunda sobre traços sensíveis ${ }^{5}$ nos quadrinhos merece atenção e pesquisa. Os trechos selecionados para a análise crítica de tradução trazem diferentes tópicos relevantes para os Estudos da Tradução. Foram escolhidas partes de vários pontos da narrativa, sendo eles do início do Estado Palestino, celebração de festas tradicionais, entrevistas e ataques militares.

A narrativa sequencial de notícias, entrevistas e dados presentes em um livro de reportagens quadrinizadas, carrega diversos fatores sensíveis. Textos que apresentam informações contrárias ao Estado, à religião, à decência ou a cidadãos específicos são comumente tidos como sensíveis, pois a percepção da relação entre nações varia de lugar para lugar, da repercussão do discurso, maneira como se retrata inferências sacras ou profanos e como determinados representantes são descritos.

A concepção de Notas sobre Gaza já adentra a esfera de sensibilidade. A coleta de dados, informações e lembranças para colocar Gaza nos holofotes de outro ponto de vista, é feita durante as visitas feitas à Khan Younis, Rafah, Tel Aviv e outras cidades. Porém, Sacco escreve, ilustra, retrata e dá voz à sua reportagem nos EUA, um país que é tradicionalmente pró-Israel. Ao se colocar como mediador sobre tudo o que aprendeu, viu e ouviu sobre os conflitos históricos, políticos e militares, Sacco vai contra a maré. Ele nada contra uma corrente que não se limita aos meios de comunicação americanos e ocidentais, mas que tem a sua força no governo, na presença e influência maciça de judeus em diversos ramos, na antipatia ou receio da divulgação da fé islâmica.

Assim, essa HQ de Sacco, bem como de outros jornalistas-cartunistas, reúne recortes sensíveis que tangem temas relacionados à política internacional, religião, decência - as representações dos massacres são bastante explícitas, e cidadãos específicos, visto que ele coloca em sua narrativa pessoas de destaque internacional como funcionários da ONU, militares, presidentes, jornalistas e ativistas.

\footnotetext{
${ }^{5}$ Temas, tópicos e questões sensíveis podem trazer algum desconforto, ser considerados tabu, profanos ou sagrados implicando em diferentes níveis de veiculação do tom, maneira, estilo e escolhas que denotam um ou outro posicionamento.
} 
A escolha de uma obra de jornalismo em quadrinhos com teor informativo, político, social e cultural que se passa no Oriente Médio se deu pela projeção que esse livro teve (e tem) nas esferas do jornalismo e dos quadrinhos. O conflito entre Israel e Palestina $^{6}$ é constante; sendo assim, é um tema sempre em voga. É comum ver na mídia os dois lados da moeda. No entanto, Sacco mostra no prefácio de Notas sobre Gaza (2010, p.VII) que escolheu focar sua narrativa somente sob o ponto de vista dos palestinos, a fim de dar uma voz e um espaço de visibilidade para os acontecimentos em Khan Younis e Rafah que foram "relegado(s) à obscuridade" no Ocidente" .

Sacco escreve Notas sobre Gaza após sua visita com outro jornalista à região. Neste segundo trabalho na Palestina, o autor se dedica a conhecer mais sobre a vida dos palestinos em dois momentos, durante os massacres em Khan Younis e Rafah ${ }^{8}$ em 1956 e durante a Segunda Intifada ${ }^{9}$. A reflexão sobre a guerra é constante na narrativa, tanto no passado (memória) como no presente.

Por que alguém se interessaria em buscar fatos e lembranças de conflitos de que ninguém se lembra? Justamente por não terem sido divulgados pela mídia e serem deixados de lado, Sacco busca conhecer um pouco sobre os massacres e as memórias dos palestinos que viveram durante aquele período (idem, p.VIII). Em suas pesquisas, o jornalista diz que seu colega de profissão Chris Hedges escreveu relatos sobre os

\footnotetext{
${ }^{6}$ Guide: Why are Israel and the Palestinians fighting over Gaza? http://www.bbc.co.uk/newsround/20436092 Acesso online em: 14 de agosto de 2015
}

\footnotetext{
${ }^{7}$ Vários fatores contribuíram para a omissão da divulgação dos massacres nessas duas cidades palestinas. Alguns deles foram: a barreira linguística (tanto do árabe quanto do hebraico), as matérias noticiadas (poucas evidências registradas em jornais e documentos) e a questão histórico-temporal (outros conflitos estavam acontecendo no momento).

${ }^{8}$ Situada ao norte de Rafah, Khan Younis fora a segunda maior cidade da Faixa de Gaza, sendo um grande centro comercial e ponto de parada na antiga rota de comércio para o Egito. Fonte:CALDER, Jean E. Where the Road Leads: An Australian woman's journey of love and determination COLOCAR MAIS DETALHES. CHATTY, Dawn; LEWANDO HUNDT, Gilian. Children of Palestine: Experiencing Forced Migration in the Middle East. New York, London: Berghahn Books, 2005. ${ }^{9}$ A Segunda Intifada, também conhecida como Intifada Al-Aqsa, eclodiu no final de setembro de 2000 com a visita de Ariel Sharon à Mesquita Al-Aqsa, na parte árabe de Jerusalém. Os palestinos viram esta visita como uma afronta, e assim começaram novamente os ataques que duraram até fevereiro de 2005. Fontes: Jerusalem Media and Communication Center - http://www.jmcc.org/fastfactspag.aspx?tname=88, BBC News - http://news.bbc.co.uk/2/hi/middle_east/3677206.stm, AMP - American Muslims for Palestine - http://www.ampalestine.org/index.php/history/the-intifadas/343-the-second-intifadaintrodouction, Crimes of War - http://www.crimesofwar.org/a-z-guide/the-second-intifada-and-after/, Memória Globo - http://memoriaglobo.globo.com/programas/jornalismo/coberturas/intifada/segundaintifada.htm. Acesso online respectivamente em: 7 de abril de 2016, 7 de abril de 2016, 8 de abril de 2016, 9 de abril e 9 de abril.
} 
acontecimentos em Khan Younis em 1956, mas por alguma razão foram cortados pela editora (idem, p.VII).

As memórias de tempos de paz são raras para os palestinos. A lembrança de tiroteios, incursões, assassinatos sem motivo é concretizada em cada esquina na Faixa de Gaza. Para coletar dados e informações, Sacco conta com a companhia diária de Abed, seu intérprete, guia e amigo. Ele tranquiliza os senhores e senhoras sobreviventes sobre as entrevistas, mostra outras reportagens de Sacco, ganha a confiança e o respeito para que o jornalista faça seu trabalho.

Apesar de ser um ofício que se torna quase automático, Abed ouve, processa e conta os relatos dramáticos, densos e palpáveis. O processo de interpretação é bastante árduo, uma vez que os discursos são carregados de emoções. O intérprete não tem como fugir dos tiros de tristeza, das granadas de desespero ou das bombas da melancolia. Ele ouve o discurso em sua língua, e em seguida, o reproduz na língua estrangeira, sendo obrigado a experimentar as emoções duas vezes, a primeira como receptor e a segunda como transmissor (DRUMMOND, 2010, p.22)

Os quadrinhos que denotam a realidade sobre outras partes do mundo, bem como de outras culturas e religiões, podem aproximar os leitores a uma realidade completamente diferente da deles. Além disso, por ser uma leitura de um texto híbrido, que agrega imagens e texto, os leitores podem ver a experiência do jornalista visualizando as ilustrações e as notas de rodapé (as entrevistas) que fazem referências diretas e indiretas aos diversos acontecimentos naquela região.

A narrativa prende a atenção do leitor com fatos históricos e traços humanizados, mostrando o lado que poucos conhecem - da dor, da guerra, da luta e da perseverança. Este livro é altamente informativo e é utilizado em algumas universidades americanas como leitura complementar em aulas de Ciência Política e Relações Internacionais (JUNEAU; SUCHAROV, 2010). A relevância dessa obra, como outras de Sacco, vai além do âmbito jornalístico e quadrinístico.

Dessa maneira, a justificativa para fazer uma análise crítica da tradução de Notas sobre Gaza se encontra no desafio de identificar traços que demonstram a sensibilidade do texto e as estratégias de tradução que o tradutor utilizou para que o texto de chegada 
tivesse os mecanismos do texto de partida.

\section{Conteúdo dos capítulos da dissertação}

A fim de nortear o andamento deste trabalho, o primeiro capítulo é destinado aos quadrinhos, dividido em três partes: a linguagem dos quadrinhos, a constituição das histórias em quadrinhos e a relevância das HQs como forma de comunicação. Assim, haverá maior detalhamento sobre a linguagem utilizadas neste hipergênero e fatores que distinguem as HQs de outros tipos de estruturas narrativas, bem como aspectos importantes da semiótica no jornalismo em quadrinhos ${ }^{10}$.

O segundo capítulo apresenta a metodologia e o referencial teórico utilizado, a fim de guiar a análise teórica. O embasamento conta com aspectos de tradução de textos sensíveis (língua, cultura, religião, política, entre outras), a abordagem funcionalista alemã (Skopostheorie e o modelo de Nord), semiótica nas HQs (signos icônicos e simbólicos), e estratégias de tradução.

O terceiro capítulo mostra a análise da crítica de trechos selecionados, levando em consideração as questões sensíveis da temática, o modelo funcionalista de Nord, as estratégias de tradução e a transcriação do texto para o português.

As considerações finais apresentam as reflexões acerca da pesquisa feita para o presente estudo, tendo como base o referencial teórico estabelecido, buscando abarcar os principais pontos e responder às perguntas estabelecidas nos objetivos.

As referências bibliográficas apresentam os trabalhos relevantes consultados e mencionados durante a pesquisa que fizeram parte do referencial teórico para que o presente estudo sobre a análise da tradução de Notas sobre Gaza fosse coeso e conciso.

\footnotetext{
${ }^{10}$ A relevância da semiótica no jornalismo em quadrinhos será explicada com mais detalhes nos exemplos da análise crítica.
} 


\section{CAPÍTULO 1 - A LINGUAGEM DOS QUADRINHOS}

\subsection{INTRODUÇÃO}

As histórias em quadrinhos (HQs) apresentam um mundo fascinante com suas imagens, diálogos e narrativas que cativam leitores de diversas faixas etárias. Por meio de uma leitura dinâmica e atrativa, é possível se deleitar com ilustrações e texto. A combinação de dois meios diferentes permite que o leitor desfrute uma leitura verbovisual que acontece em vários níveis. Sendo assim, a grande diferença das HQs é uma linguagem específica com formato convencionado e reconhecido pelos leitores.

A linguagem dos quadrinhos abarca vários gêneros. Segundo Ramos (2012a, p.21), são eles "os cartuns, as charges, as tiras cômicas, as tiras cômicas seriadas, as tiras seriadas, e os vários modos de produção das histórias em quadrinhos". O que se pode notar em comum nelas são a sequência narrativa, a tendência de imagens desenhadas, histórias com personagens fixos ou não, o veículo de publicação, entre outros. A nomenclatura "história em quadrinhos", então, é entendida por Ramos como um hipergênero ou grande rótulo que "agrega vários gêneros que compartilham uma mesma linguagem em textos predominantemente narrativos" (idem, p.20).

Os quadros, assim como as vinhetas no cinema, apresentam situações e momentos e cenários dentro de uma narrativa contínua. Entretanto, diferentemente dos filmes, as imagens são estáticas (MUANIS, 2006). De acordo com Eisner (2012, p.20), o desafio de simular o movimento real "proporciona aos quadrinhos a singular possibilidade de permitir a leitura de várias imagens ao mesmo tempo, ou a partir de pontos de vista diferentes, algo impossível de reproduzir no cinema”.

A história se constrói por meio de uma sequência de quadros. É possível ter quadros sequenciais que mostram uma personagem correndo, a mudança de cenário e enfoques diferentes de acordo com o ângulo que o ilustrador quer enfatizar. Com uso de 
elementos específicos aos quadrinhos, como balões de fala, onomatopeias, linhas cinéticas, expressões faciais e símbolos convencionados, é possível inferir se há diálogo, sons e interjeições, movimento, emoções etc.

A narrativa em uma HQ ocorre tanto no código verbal como no código visual. Volli (2007, p.289) explica que "nos quadrinhos as palavras não possuem um valor autônomo em relação às imagens, mas são apenas um componente em um jogo mais amplo". As palavras desempenham um papel de dependência quando estão relacionadas às imagens. A correspondência visual entre as partes imagéticas e verbais estão intimamente ligadas; assim, elas não independentes. Entretanto, quando não estabelecerem uma associação indicial, elas não precisam ser vinculadas estritamente à imagem.

A narrativa é movimentada pela junção das palavras e imagens. Há uma multiplicidade de sistemas que se correlacionam a fim de criar um tecido narrativo com diferentes camadas. Trata-se, portanto, de um texto multimodal. Segundo Marcuschi (2008, p.80 apud RAMOS, 2012a, p.744), "numa orientação de multissistemas [...] envolve tanto aspectos linguísticos como não-linguísticos no seu processamento (imagem, música) e o texto se torna em geral multimodal".

\subsection{A CONSTITUIÇÃO DA HISTÓRIA EM QUADRINHOS}

Os quadrinhos são constituídos por elementos que distinguem este tipo de texto de outros. Os principais constituintes são as imagens ou figuras, as linhas ou molduras que delimitam o espaço, e o discurso escrito que pode aparecer nos balóes de fala, na legenda e nas onomatopeias (CAGNIN, 2014, p. 34).

A narrativa sequencial usa os elementos visuais para compor a história. As imagens denotam o cenário, a situação e as personagens. A moldura estabelece o espaço do quadro no qual a situação ocorrerá, podendo ser de tamanho regular, como é 
comumente visto nas tiras, ou de tamanho irregular, a fim de dar uma conotação de espaço ou tempo por meio de alongamento ou encurtamento do quadro. O texto verbal, de extrema importância no código verbal, é inserido em diferentes espaços, como nos balões (de fala, de pensamento, de sonho), na legenda como um elemento de tempo ou espaço, ou em espaços destinados às onomatopeias.

Na figura abaixo (Figura 1), é possível ver a sequência de três vinhetas do mesmo tamanho em ângulos diferentes demarcadas pela moldura, uma legenda no primeiro quadro e um balão de fala que indica que o personagem fala com alguém.
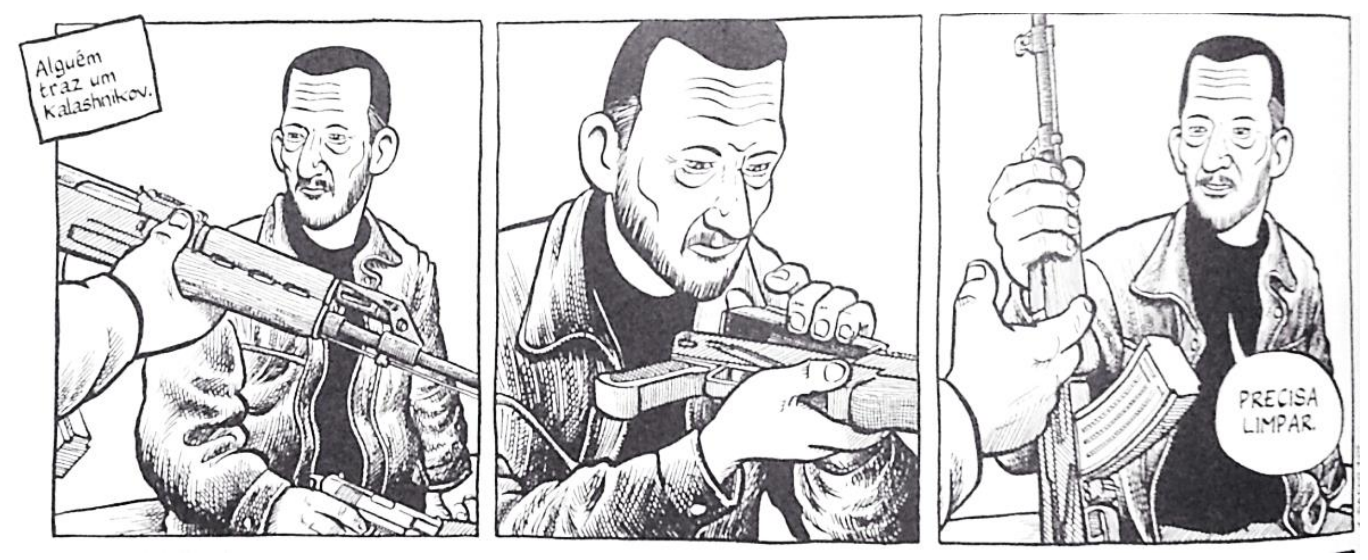

Figura 1. Vinhetas, legenda e balão de fala

Fonte: Notas sobre Gaza (SACCO, 2010, p.10).

Uma única imagem pode veicular diferentes frases, proporcionando uma multiplicidade de conotações. O entrelaçamento da ilustração com texto escrito permite que o leitor complemente as informações presentes em um ou mais planos para ter uma compreensão do todo. Além disso, os espaços entre os quadros, chamados de sarjetas ou canaletas (MCCLOUD, 2004; CHINEN, 2015), são preenchidos pelas experiências e informações prévias de cada leitor transformando a sequência de quadros em uma única ideia (MCCLOUD, 2004, p.66).

As falas presentes na narrativa sequencial "são representadas com o auxílio de balões" (RAMOS, 2012a, p.32). Estes não se limitam ao uso de diálogos. Eles podem expressar o discurso pensado, caso forem apresentados no formato de nuvem, por exemplo. O balão pode ter várias formas e com contornos diferentes convencionados 
nos desenhos para passar sensações diferentes. Um contorno contínuo, reto ou curvo designa um balão-fala, linhas tracejadas compõem o balão-cochicho, linhas curvilíneas em vai e vem na parte de baixo do balão indicam um balão-glacial, comumente usado para indicar desprezo ou choro (idem, p. 38). O uso de contornos, tracejados e outras técnicas de desenho permite uma simulação de aspectos audíveis.

O discurso escrito faz parte do código textual, mas também do visual. Para Eisner (2012, p.2), “O tratamento visual das palavras como formas da arte gráfica faz parte do vocabulário." O letreiramento pode dar uma leitura diferente a uma determinada palavra e pode acrescentar um novo sentido e ser considerado como uma extensão da imagem da mesma forma que o uso de negrito, caixa alta, itálico, e outras cores influenciam como o leitor lê e compreende a história. Esses elementos denotam a presença da função poética reforçando pela expressão verbovisual o aspecto estético do texto multimodal. Eisner (idem, p.4) discorre sobre o letreiramento e diz que ele "fornece o clima emocional, uma ponte narrativa, e a sugestão de som".

A linguagem dos quadrinhos, por ser convencionada, permite que a ilustração de imagens evoque emoções de acordo com os tipos de linhas, traços, formas e cores empregadas no desenho. Linhas sinuosas, traços fracos e turbulentos, formas pontiagudas e cores que evocam sentimentos diferentes são vitais nos quadrinhos. $\mathrm{O}$ vermelho pode ser interpretado como uma cor brava, o azul como plácido, já o verde como uma cor fria, e a repetição de traços pode render uma textura ansiosa, as formas podem se tornar barulhentas (MCCLOUD, 2004, p. 123).

Os quadrinhos são compostos de vinhetas estáticas; assim, há somente uma emulação de gestos por meio de posicionamento de objetos ou linhas de movimento. Para dar a ideia de movimento, os desenhistas utilizam formas para representar uma ação, "como uma xícara inclinada sobre uma mesa, indicando que está na iminência de cair” (RAMOS, 2012a, p.116). Infere-se que a xícara está na beira da mesa e também que ela está caindo. Não há movimento nos quadrinhos como nos filmes. Outra alternativa de alcançar essa ilusão é por meio de linhas cinéticas. Assim, a simulação de movimento é destacada com "o uso de signos de contorno ligados a um objeto ou personagem, indicando uma trajetória" (idem). Na figura 2, as linhas cinéticas indicam a 
força, a velocidade e o impacto do tapa de um oficial egípcio no rosto de Khaled, um dos entrevistados de Sacco que fazia parte da resistência Palestina.

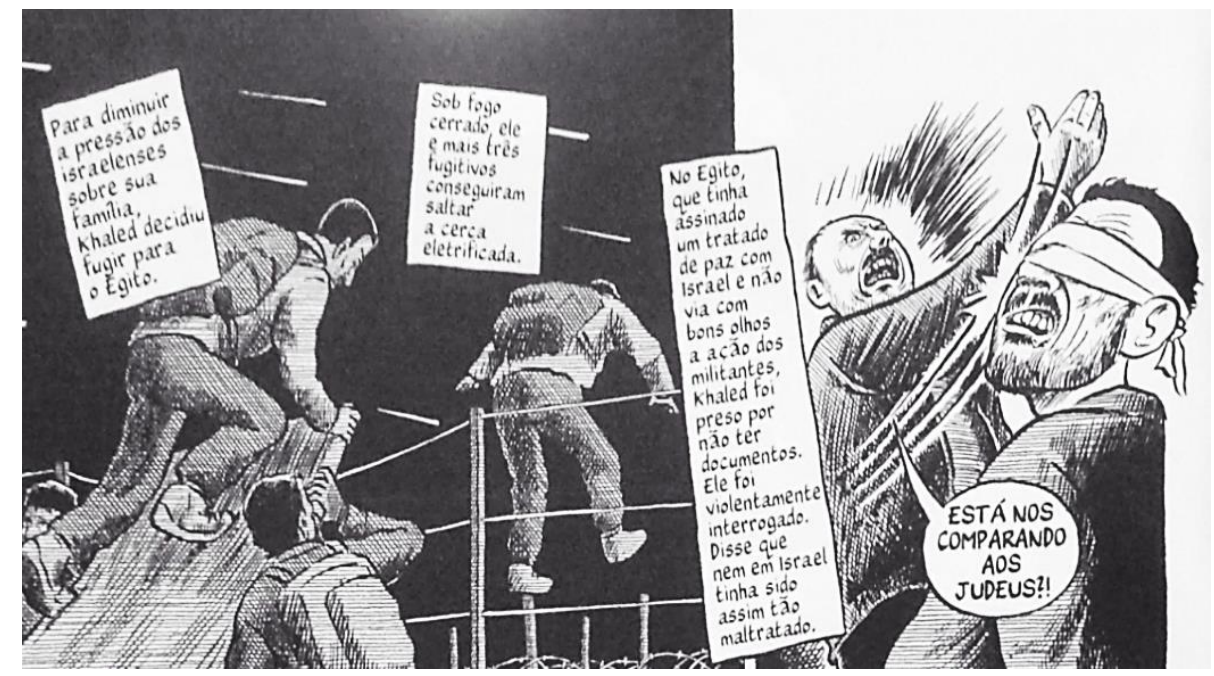

Figura 2. Linhas cinéticas

Fonte: Notas sobre Gaza (SACCO, 2010, p.52).

As linhas podem ser usadas para designar outras coisas. Elas podem indicar a fumaça que sai de um cigarro, assim como representar o cheiro forte de lixo saindo de uma lata. Em ambos os exemplos as linhas mostram interpretações diferentes. No primeiro caso, as linhas apontam a fumaça, "um fenômeno visível, enquanto o outro representa um invisível - o cheiro" (MCCLOUD, 2004, p.128).

Além desses fatores, a maneira como um personagem é desenhado influencia no modo como a metáfora visual é composta. Ramos (2012a, pp. 114-115) explica que "as expressões faciais e as metáforas visuais se somam aos gestos dos personagens e à postura do corpo. Ambos têm de estar em perfeita sintonia com a imagem representada, de modo a reforçar o sentido pretendido". 


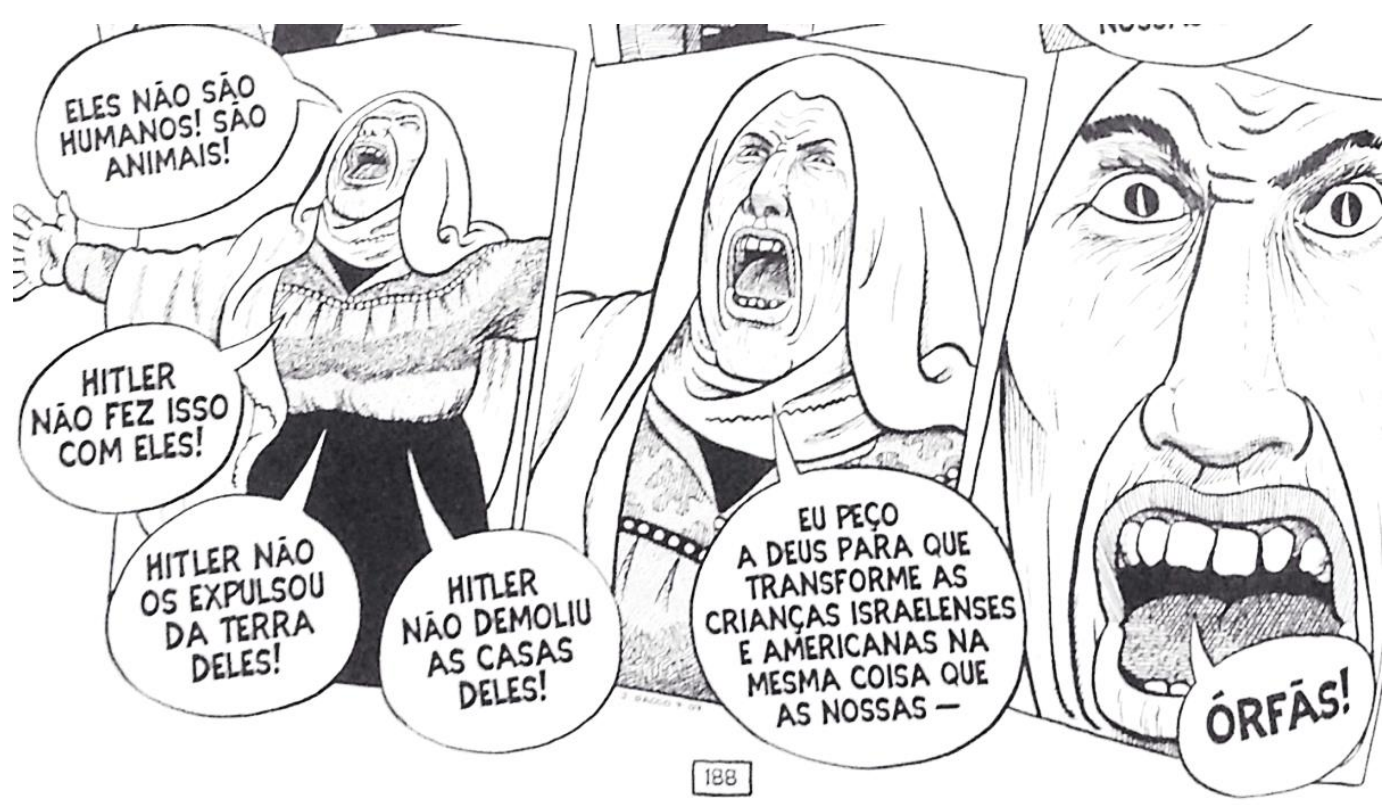

Figura 3. Expressões faciais

Fonte: Notas sobre Gaza (SACCO, 2010, p.188).

Na figura acima (Figura 3), pode-se notar que os quadros estão inclinados. Este foi um artifício usado para mostrar que nada está no lugar. Na página anterior, um tanque de guerra israelense passa pela região destruindo caminhos, muros e casas. A expressão da senhora é de desespero e revolta. Detalhes como gestos, expressões, postura, roupas e demais itens contribuem com a temática e valorizam a história contada. O mesmo vale para o uso de close up e extreme close up ${ }^{11}$ em aproximação nos quatro quadros da mulher falando que faz com que o leitor perceba um desespero crescente da personagem.

É possível expressar a passagem de tempo por meio da narrativa visual. A capacidade de transpor essa dimensão permite "reconhecer e compartilhar emocionalmente a surpresa, o humor, o terror e todo âmbito da experiência humana"

\footnotetext{
${ }^{11}$ A composição quadrinhística teve influência de técnicas cinematográficas. Assim, cerca de sete planos podem ser identificados em narrativas de HQs. São eles panorâmico, conjunto, americano, médio, primeiro plano e plano em grande detalhe. O close up é o "primeiro plano, que permite ver a personagem ao nível dos ombros, possibilitando uma melhor visualização do seu rosto" (OLIVEIRA, sem data) O extreme close up é o plano em grande detalhe mostrando os pormenores da imagem, "revelando assim uma maior força expressiva" (idem) Fonte: Grupo de Pesquisa - Produções Literárias e Culturais para Crianças e Jovens. http://grupoplccj.webnode.com.br/quadrinhos/. Acesso online em 20 de abril de 2016.
} 
(EISNER, 2012, p.24). Assim, outro aspecto importante presente na constituição dos quadrinhos é o timing.

Para alcançar a noção de que o tempo está em andamento, a disposição e a sequência dos quadros são de extrema importância. Expressa-se essa sensação "por meio do uso de ilusões e símbolos e do seu ordenamento" (idem). Uma sequência de quadros com uma torneira pingando lentamente pode dar a ideia de um minuto, o cenário passando de dia, para tarde, depois para noite permite que o leitor compreenda que se passou um dia. Para McCloud (2004, p.99), "O quadro age como um tipo de indicador geral de que o tempo ou espaço está sendo dividido". Porém, o ilustrador ressalta que não é o quadro em si que define a duração do tempo, nem a dimensão do espaço, e sim o conteúdo apresentado em sequência. Isto é viável na figura (Figura 4) em que a troca do cenário atrás das pessoas transmite não somente o deslocamento no espaço, mas também o decorrer do tempo. 


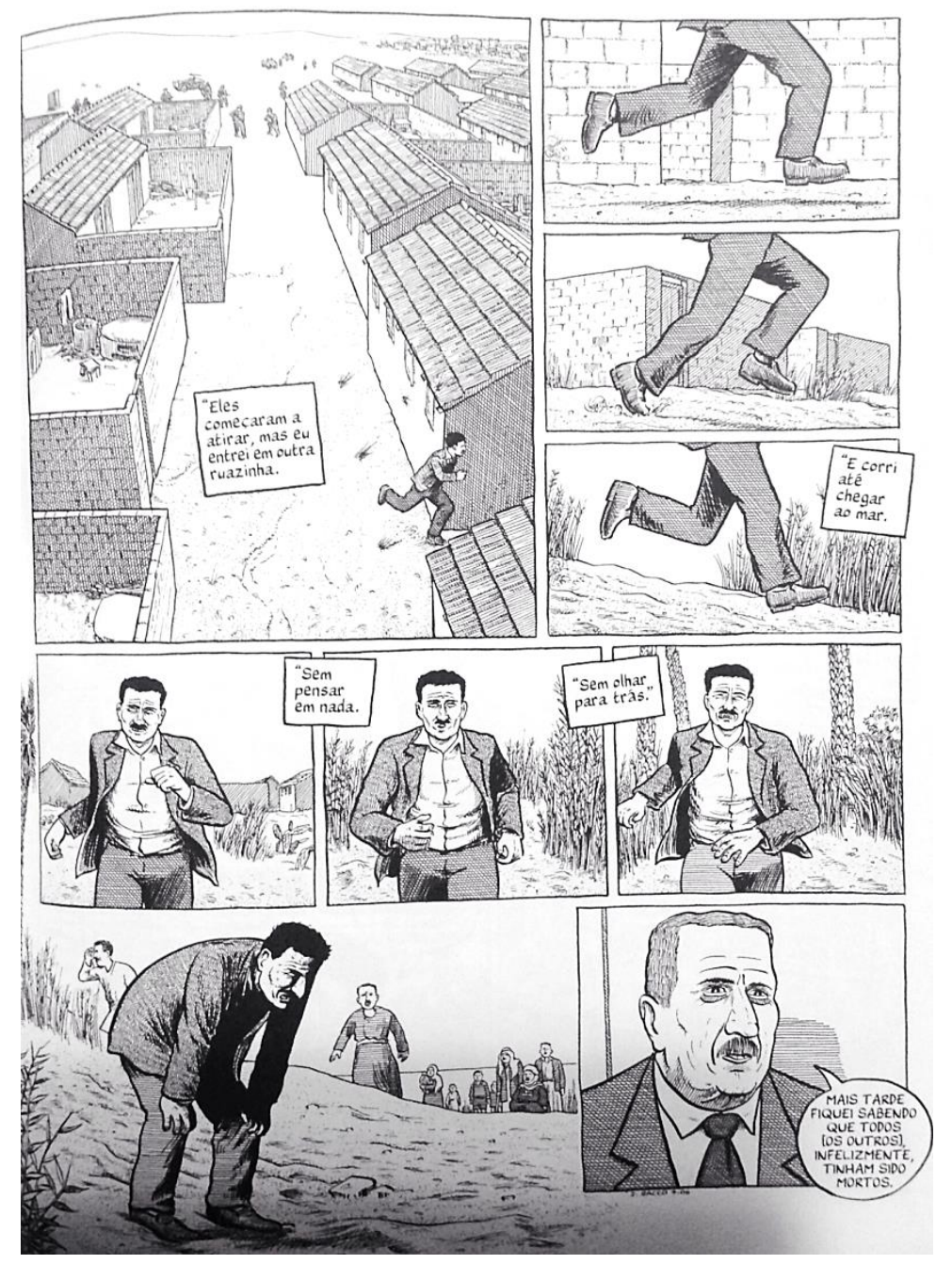

Figura 4. Tempo (timing)

Fonte: Notas sobre Gaza (SACCO, 2010, p. 107).

\subsection{A RELEVÂNCIA DAS HQS}

As HQs nem sempre tiveram o prestígio que têm hoje. Durante muito tempo, foram consideradas como uma forma inferior de narrativa destinada somente ao público infanto-juvenil. Porém, elas hoje desfrutam de reconhecimento em várias esferas pelos conteúdos e formas de representação de textos fictícios e não fictícios.

No ano de 2006, as HQs foram incluídas no Programa Nacional Biblioteca na Escola (PNBE). Tiras autorais, adaptações literárias, biografias, entre outros entraram na lista de livros em quadrinhos adotados pelo programa. Segundo Ramos, 
A inclusão de obras em quadrinhos segue a orientação dos Parâmetros Curriculares Nacionais, elaborados no fim dos anos 90, ainda sob a orientação de Fernando Henrique Cardoso. Os parâmetros - mais conhecidos pela sigla PCN - têm como eixo central a necessidade da leitura de textos de diversos gêneros (RAMOS, 2012b, p.224).

O número de solicitações de álbuns aumentou com o passar dos anos. Em 2006, sete álbuns foram incluídos; já em 2007, foram dez. Em 2008, o PNBE teve 21 álbuns em sua lista, sendo eles para ensino fundamental e médio. A inclusão de obras em quadrinhos mostrou diversificação em conteúdo. Autores nacionais e estrangeiros foram incluídos, como Laerte, Ziraldo, Fernando Gonsales, Gosciny e Uderzo e Will Eisner (idem, p.226).

As adaptações literárias são um reflexo de um movimento editorial. É um mercado que mostra tendência de adaptação de contos e romances da literatura nacional e estrangeira que visa um público jovem e adulto. Vários estudos na academia foram surgindo com a aceitação de quadrinhos nas escolas. Um desses exemplos é a dissertação de mestrado de Lielson Zeni, "A Metamorfose da Linguagem: Análise de Kafka em Quadrinhos”. Uma das conclusões a que o autor chegou foi a de que a adaptação de uma obra original possibilita outro tipo de leitura para o público dos quadrinhos. Entretanto, a adaptação não é a leitura definitiva (idem, p.249).

Pode-se ver o destaque que as adaptações literárias em HQs tiveram com a premiação da adaptação de O Alienista, em 2008. O trabalho de ilustração foi feito por Gabriel Bá e Fábio Moon ${ }^{12}$ e venceu o Prêmio Jabuti na categoria álbum didático e paradidático (idem, p.257). Além de ser uma adaptação de uma obra de destaque, os quadrinistas Bá e Moon são autores de outros romances gráficos que dão legitimidade para que esse romance gráfico seja inserido no âmbito escolar.

Os quadrinhos "baseados em fatos reais" ganharam popularidade com narrativas que mostravam fatos e cenas da realidade. Ramos (2012b) divide esses tipos de quadrinhos em quatro grupos: 1. Acontecimentos históricos; 2. Reportagens em quadrinhos; 3. Biografias de personalidades marcantes, e 4. Confissões autobiográficas.

\footnotetext{
${ }^{12}$ Dois quadrinistas renomados que foram responsáveis pela adaptação de $O$ alienista e Dois irmãos.
} 
Os quadrinhos cujo intuito primordial é recontar acontecimentos históricos ganharam destaque por serem uma forma acessível ao público juvenil de conhecer fatos que muitas vezes foram deixados de lado. A série Passos perdidos, história desenhada contou com vários volumes sobre a presença judaica em Pernambuco (idem, p.286). O trabalho de Joe Sacco, por exemplo, deu início ao movimento de reportagens, ou jornalismo, em quadrinhos. Notas sobre Gaza, reportagem que narra o conflito entre israelenses e palestinos no ano de 1956, destaca o evento que antes estava confinado às "notas de rodapé" (termo literal do título em inglês Footnotes in Gaza) nos livros de história (idem, p.306). A biographic novel, intitulada Santô: e os pais da aviação, rendeu ao Spacca - João Spacca de Oliveira - quatro Troféus HQMix em 2006 (idem, p.276). Por fim, a obra de Alison Bechdel, Fun Home - uma tragicomédia em família, mostra um tom autobiográfico ao retratar os conflitos pessoais com seu pai. Em 2006, a obra foi citada pela revista Time como livro do ano e está no mesmo patamar de Maus, considerada como uma obra formadora de opinião (idem, p.284).

Assim, vê-se que as histórias em quadrinhos de diferentes vertentes ganharam espaço nas escolas com apoio do governo, as editoras perceberam a revolução das HQs e as possibilidades de inovações com adaptações literárias, biografias, jornalismo em quadrinhos, que vão muito além dos gibis.

As reportagens em quadrinhos se tornaram relevantes não só no âmbito do jornalismo e dos quadrinhos, como também ganharam espaço no âmbito acadêmico, legitimando, assim as notícias em narrativas sequenciais. Juneau e Sucharov (2010) defendem o uso de romances gráficos nas aulas de Ciência Política e Relações Internacionais em universidades americanas. Além disso, segundo Scherr (2015), a obra de Sacco pode ser usada para entender mais sobre os Direitos Humanos.

O uso de textos multimodais em sala de aula pode enfatizar aspectos que a prosa não abarca. Por exemplo, em Palestina, de Joe Sacco, toda vez que o autor-personagem está do lado de fora a moldura do quadro aparece enlameada, o céu sempre escuro e com nuvens. O recurso de mostrar a lama em todos os quadros aponta a diferença entre ambiente interno e externo, mas, principalmente, indica a possibilidade de o leitor 
visualizar a frase "há lama em tudo que é lugar"13", que não é possível de se reproduzir em todos os parágrafos de um texto em prosa. A repetição desse recurso permite que os leitores associem a imagem com o conceito de uma "infraestrutura em ruínas, subdesenvolvimento econômico, e desespero geral que caracterizam a vida na Cisjordânia e em Gaza ${ }^{14, "}$ (idem, p.174)

Os romances gráficos com conteúdo político combinam textos e informações visuais fortes para uma visão mais íntima e pessoal sobre questões e problemas reais. Os textos teóricos básicos não são substituídos por quadrinhos de conteúdo político e histórico, mas estes são utilizados juntamente, pois fornecem exemplos concretos de generalizações abstratas e ajudam os alunos a compreenderem conceitos teóricos de maneira indutiva (idem, p.175).

A complementação das leituras com romances gráficos "fornece aos alunos uma perspectiva única sobre tópicos sensíveis, como sobre o conflito entre Israel e Palestina, e ajudam os alunos a desenvolverem empatia e habilidades de pensamento crítico ${ }^{15,}$ (idem, p.181). Sacco alcança o público adulto, bem como jovens que estão no colégio e na universidade. Com temas difíceis, mas com os recursos visuais, "é uma maneira mais fácil de abordar um assunto". Além disso, "Os desenhos proporcionam mais intensidade. Pode ser mais fácil, mas não é superficial. Você lê e percebe que há profundidade" (SACCO, 2011, s/p)

\footnotetext{
${ }^{13}$ Em inglês, "there is mud everywhere” (todas as traduções foram feitas por mim)

${ }^{14}$ Em inglês, "crumbling infrastructure, economic underdevelopment, and general desperation characterizing life in the West Bank and Gaza"

${ }^{15}$ Em inglês, "provide students with a unique perspective on sensitive topics such as the IsraeliPalestinian conflict, and help them develop empathic and critical-thinking skills"
} 


\subsection{SOBRE O JORNALISMO EM QUADRINHOS}

O jornalismo pode ser veiculado de diferentes formas. É comum ver notícias em jornais, revistas, ouvi-las no rádio ou na televisão. Podem-se contar histórias de cunho jornalístico por meio de textos, fotografias e histórias em quadrinhos.

As histórias em quadrinhos foram ganhando espaço com o passar do tempo e foram abordando temáticas diferentes. Para se entender como o jornalismo em quadrinhos conseguiu ser legitimado por Sacco nos anos 90, é necessário traçar um panorama das tradições anteriores.

Na década de 50, após uma onda de inserção de temáticas violentas relacionadas a guerras, as HQs sofreram com uma censura de conteúdo e passaram a ser destinadas prioritariamente ao público infanto-juvenil. No entanto, foi nos anos 60 que houve um aumento na liberdade autoral, abrindo o território para quadrinhos independentes. Diversas HQs autobiográficas começaram a ser publicadas e se tornaram ícones e bestsellers. Porém, no início da década de 70, as revistas underground começaram a mostrar uma contracorrente. Segundo Oliveira e Passos (2006), foi a partir daí que houve "a reinserção de relativa violência e problemas sociais nas tramas". Robert Crumb, grande expoente da vertente underground, já publicava HQs "impregnadas por impressões e histórias pessoais" (ibid).

Quadrinhos sobre óticas e relacionamentos variados mostram a pluralidade de assuntos inerentes ao ser humano e ao contexto em que se está inserido. Autores como Art Spiegelman, Kenji Nakazawa, Marjane Satrapi, Will Eisner, entre outros, retrataram suas experiências pessoais inseridas em temáticas fortes e em diferentes países. Spiegelman, autor de Maus, foi um dos quadrinistas que mais se destacou. Sua obra conta a história de seu pai, Vladek, antes, durante e depois do Holocausto. Com relatos pessoais e históricos, Spiegelman dialoga com um passado bastante vívido que difunde memórias e experiências vistas de outra perspectiva. Para Spiegelman:

Os quadrinhos são um meio de expressão bastante denso. Transmitem informações muito concentradas em relativamente poucas palavras e imagens-código simples. Isso parece ser um modelo de como o cérebro 
formula pensamentos e lembranças. Pensamos na forma de desenhos. Os quadrinhos tem demonstrado com frequência como servem bem para contar histórias de aventuras cheias de ação ou humor, mas a pequena escala de imagens e o caráter direto desse meio, que tem algo a ver com a escrita à mão, permitem aos quadrinhos um tipo de intimidade que também os torna surpreendentemente adequados para autobiografia (SPIEGELMAN, 2001, p. VII-VIII).

Outros trabalhos como Gen: pés descalços, de Keiji Nakazawa, escrito na década de 70, tem como tema a explosão atômica em Hiroshima, no Japão. Will Eisner, em No coração da tempestade, também relata experiências pessoais com o pano de fundo das duas Guerras Mundiais. Além desses, Marjane Satrapi, uma das quadrinhístas mais conhecidas desta linha, conta a infância e adolescência no Irã durante a tomada de poder pelo aiatolá Khomeini. Essas obras autobiográficas abriram caminho para o jornalismo em quadrinhos. A importância de se relatar histórias verídicas vai além do espectro pessoal e local; portas se abriram para reportagens de um ponto de vista subjetivo, mas ao mesmo tempo factual e documental.

O jornalismo em quadrinhos foi sistematizado, como já mencionado, a partir das obras de Joe Sacco. Vários estudiosos dizem que a obra Palestina foi o pilar da consolidação desse gênero (ROSSONI, LIMA, 2011; GOMES, 2010; SÁ, 2013). É possível relacionar a narrativa do jornalismo com o mundo da fotografia. A maneira como as pessoas são enquadradas, o foco das imagens e os inúmeros detalhes cenográficos indicam que há um diálogo entre fotos e ilustrações.

O modo fotográfico do enquadramento agrega aspectos ligados ao formato de documentário. O traço fotográfico de Sacco em Notas sobre Gaza está no uso dos retratos. Para Scherr (2015a), a atenção meticulosa ao desenho, aos enquadramentos dos rostos dos entrevistados, o zoom mais próximo em diferentes aspetos do rosto (ver Figura 3 acima) revela a relação não só com a fotografia, mas também com o cinema.

Em uma reportagem quadrinizada, "são os quadrinhos que arquitetam a narrativa e que, na sequência das imagens, guiam a leitura da notícia" (GOMES, 2010, p.41). Ao invés do jornalismo convencional, as obras jornalísticas em quadrinhos são repletas de subjetividade por parte do jornalista, uma vez que ele é também participante ativo da história. De acordo com Gomes: 
Não se tenta em nenhum momento esconder o olhar do repórter ou a sua participação e envolvimento, pois é justamente esta a característica reflexiva presente nos documentários: o narrador torna-se parte integrante da paisagem: neste caso, uma metalinguagem ilustrada que se altera no decorrer da narrativa numa espécie de catarse reflexiva sobre sua própria condição (GOMES, 2010, p. 46).

Uma das preocupações com este tipo de reportagem é transmitir visões subjetivas. A objetividade jornalística, segundo Arbex (2000), é um mito, pois a transmissão da realidade é feita sempre a partir de um único ponto de vista, "não mostra O mundo, mas UM mundo". Assim, de forma totalmente inovadora, o jornalismo em quadrinhos apresenta em sua estética uma visão singular, um testemunho subjetivo, mas com embasamentos objetivos do autor que está inserido na trama. O roteiro, os cenários, os personagens e demais partes da narrativa mostram a relevância e o valor estético da obra.

\subsection{A REPORTAGEM EM QUADRINHOS DE JOE SACCO: NOTAS SOBRE GAZA}

\subsubsection{Joe Sacco: o jornalista e cartunista de zonas de conflito}

Muitos acreditam que Joe Sacco seja americano. Na verdade, o jornalista nasceu em dois de outubro de 1960, em Malta. Até os onze anos de idade, Sacco morou na Austrália. Em 1972, mudou-se para Los Angeles, nos Estados Unidos. Estudou jornalismo na Universidade de Oregon, onde se formou em 1981. Passou grande parte da década de 80 morando na Europa. Trabalhou como cartunista, editor chefe e editor de arte para várias publicações, inclusive para a The Comics Journal ${ }^{16}$.

\footnotetext{
${ }^{16}$ Fonte: http://www.bookreporter.com/authors/joe-sacco Acesso online em 2 de fevereiro de 2016.
} 
Sua primeira viagem ao Oriente Médio foi em 1992. Após sua experiência em Israel e em territórios ocupados, Sacco compilou o material necessário para escrever seu primeiro livro de jornalismo em quadrinhos ${ }^{17}$ : Palestina - uma nação ocupada. Com esse marco, outras reportagens em HQ se seguiram, como Natal com Karadzic, na coletânea Comic Book: o novo quadrinho norte-americano, Área de segurança Gorazde, A guerra na Bósnia oriental 1992-1995, Jornalismo, entre outras. Em 1996, Sacco foi premiado com o American Book Award pela série sobre a Palestina.

Em uma entrevista para a rede $\mathrm{Al}$ jazeera ${ }^{18}$, Sacco revelou que nunca pensou que seus quadrinhos seriam um caminho para a sua carreira como jornalista. Fazer HQs sempre foi sua paixão, assim como ser um repórter de verdade.

Segundo Negri (2003, página/s),

O 'pai' do novo estilo trabalha com conceitos comuns utilizados pelos repórteres, no seu caso, aproximando-se do estilo new jornalism norteamericano [...]. O que ele faz é, ao invés de transformar o material em texto jornalístico, transformá-lo em história em quadrinhos (NEGRI, 2003).

O novo estilo no âmbito do new jornalism traz relatos reais em preto e branco na obra de Sacco, quadros que se assemelham a fotografias e uma narrativa da arte sequencial que abrange a vertente visual da obra, como também literária. No prefácio da edição Palestina - uma nação ocupada, Arbex (2000) ressalta que, com a ousadia da reportagem em quadrinhos de Sacco, ele atinge, em certos aspectos, um nível de eficácia que vai além do texto tradicional jornalístico. A linguagem de HQ parece não ser compatível com outros meios de veicular informações jornalísticas; porém, Sacco fez uso de uma linguagem tão completa e poderosa para retratar um tema como conflitos em zonas de guerra que valorizou e destacou a sua reportagem entre tantas outras. Assim, a mídia quadrinhística reivindica um espaço para ser legitimada, não só como entretenimento, mas também como reportagem jornalística, séria e engajada.

\footnotetext{
${ }^{17}$ Um dos gêneros das HQs explicado no item 1.5.

${ }^{18}$ Fonte: http://www.aljazeera.com/news/middleeast/2007/11/2008525185042679346.html Acesso online em 2 de fevereiro de 2016.
} 


\subsubsection{O jornalismo em quadrinhos de Sacco}

"Você pode contar [uma história] de maneira morta e sem vida ou você pode contá-la como uma história de seres humanos interagindo entre si. Eu simplesmente escolhi a segunda opção" 19 - Joe Sacco

Em entrevista para a Believer (2011), Sacco diz ser tradicionalista, de certa forma, como um cartunista da vanguarda. Foi influenciado por Crumb e usa técnicas de roteiro que são básicas a fim de veicular suas histórias. Ele já fazia quadrinhos para documentar uma banda de rock que estava fazendo uma turnê na Europa. Durante esse tempo, Sacco escrevia tudo o que os integrantes diziam, queria relatar todas as experiências da banda. A partir da abordagem e influência dos quadrinhos underground, o jornalista buscou retratar sua experiência na Palestina com base em sua própria ótica e experiência.

O cartunista conta, em entrevista para Mother Jones em 2005, que queria fazer quadrinhos mais autobiográficos quando foi para a Palestina, mas acabou se tornando algo mais jornalístico. Em busca de mais informações, ele entrevistou os habitantes locais, foi atrás de fatos e números. O processo serviu para documentar as informações e dados. Depois que se tornou consciente que se tratava de quadrinhos, mas ao mesmo tempo de uma reportagem.

A produção de uma publicação em quadrinhos envolve fatores como cores, acabamento, brochura, lombada e tipo de capa, assim como os processos de impressão. Produzir uma HQ colorida custa mais caro que uma em P\&B (preto e branco). A impressão é feita na cor preta sob o papel branco. Por ser uma cor maciça, também chamada de chapada,

${ }^{19}$ Em inglês, "You can tell [a story] in a dead and lifeless way or you can tell it as a story of human beings interacting with each other. I simply choose to do the latter." - Joe Sacco 
[...] é possível obter tons intermediários por meio de retículas aplicadas eletronicamente ou pelo próprio artista no original, que pode traçar hachuras, pontinhos ou linhas cruzadas para obter diferentes gradações de cinza. A vantagem da impressão em $P \& B$ é revelar a qualidade do traço do autor, cujas eventuais deficiências de desenho as cores tendem a disfarçar (CHINEN, 2015, 86).

Além disso, o tipo de impressão em cores é uma evidência de qual público-alvo a leitura em quadrinhos se destina. Gibis em sua grande maioria são coloridos, uma vez que as cores chamam a atenção das crianças. Adultos são mais receptivos a publicações em P\&B. Chinen (idem) explica que "os gibis da Turma da Mônica, de Maurício de Sousa, são coloridos, já a Turma da Mônica Jovem não têm cor". De acordo com McCloud (2004, p.192), "Em preto e branco, as ideias por trás da arte são comunicadas de maneira mais direta, o significado transcende a forma" (grifo do autor).

As vertentes diferentes dos quadrinhos assumem personalidades próprias de acordo com o estilo usado. Os quadrinhos independentes e alternativos provocam com seus temas e também com a forma de comunicar a história. Quadrinhos em preto e branco e quadrinhos coloridos são distintos. Porém, não somente pela cor, mas pelas técnicas, estilo de impressão e editora responsável pela publicação.

A tendência de se fazer HQs em preto e branco, tanto autobiográficos, como de reportagens, ocorre por causa da influência dos quadrinhos underground. Além de terem contribuído para temáticas mais realistas e pessoais, as tiragens eram pequenas e imprimi-las em cores significa encarecer o trabalho. Em uma troca de correspondência eletrônica com Érico Assis ${ }^{20}$, ele explica que "o quadrinista independente/alternativo já tem um estilo de desenho feito para o preto e branco. Se fossem desenhar para cores, desenhariam de outra forma".

Sacco começou a publicar seus primeiros trabalhos pela editora Fantagraphics, como Palestina. É uma editora de pequeno porte que publicava, com pequenas tiragens, HQs em preto e branco de cartunistas independentes. Nesta época, outras publicações da editora tinham desenhos parecidos com o de Sacco, "embora praticamente ninguém fizesse jornalismo em quadrinhos" (ASSIS, 2015, s/p). Devido a estar inserido na

\footnotetext{
${ }^{20}$ Érico Assis é tradutor de quadrinhos. Traduz diversos tipos de HQs para grandes editoras, como Companhia das Letras e Panini.
} 
tradição de quadrinhos alternativos, mesmo que publicasse seus trabalhos em editoras maiores, o estilo independente permaneceria.

A obra de Joe Sacco atrai a atenção dos leitores para problemas sociais e políticos relevantes. Para ele, "Os quadrinhos têm muito apelo em razão das imagens. Assim, você conquista o leitor, é capaz de contar a ele histórias difíceis e introduzir a informação" (SACCO apud STAROBINAS, 2001, p.E2). Por usar um gênero híbrido, Sacco consegue transportar o leitor para a realidade das histórias ali presentes. Em entrevista para o Guia do Estudante, o autor diz que

O poder dos quadrinhos é que, quando você abre o livro, você imediatamente é transportado para um novo lugar. Pode andar pelas ruas de Gaza. Você vê as pessoas, seus rostos, toda a interação com o cenário. Isso é muito poderoso, cria-se uma atmosfera completa na mente do leitor (SACCO, 2011).

O autor tenta descrever as coisas de forma fiel e desenhar o roteiro de forma adequada. Um dos pesares é que há tantos detalhes a serem reproduzidos que não é sempre que o retrato é adequado. Ao desenhar uma cidade, retratar os soldados, e mostrar aspectos relativos à realidade na Faixa de Gaza, Sacco não tem uma abordagem na qual as fotos devem representar todos os detalhes inerentes ao local. No entanto, ao ilustrar o cenário de uma cidade, por exemplo, ele desenha de forma que a cidade seja reconhecível de acordo com o que está sendo retratado ${ }^{21}$.

É necessário ressaltar também que o cartunista aparece em suas reportagens. Desenhado de forma caricatural, como outros personagens, Sacco mistura em seus quadrinhos os relatos de suas experiências (vertente autobiográfica) com os dados sobre os massacres (vertente jornalística). Além disso, o autor quer ter um relacionamento com o leitor. Em sua obra, a intenção era criar um diálogo, mostrar os acontecimentos de forma fluida, como em uma conversa: "Por isso que quero que essa informalidade apareça, pelo processo de me ter como personagem" ${ }^{22}$.

\footnotetext{
${ }^{21}$ Em entrevista para Dawn em março de 2015, Sacco fala sobre a sua estética relacionada ao jornalismo que busca ser fiel ao retratar as informações coletadas, tanto no âmbito linguístico, como extralinguístico. Fonte: http://www.dawn.com/news/1166290 Acesso online em 3 de fevereiro de 2016.

${ }^{22}$ Em inglês, "That is why I want this informality to appear, through the process of having me as a character".
} 


\subsubsection{O livro em quadrinhos Notas sobre Gaza}

A ligação entre quadrinhos e jornais esteve sempre presente. Em cadernos de entretenimento, as tiras (cômicas, seriadas, livres) cumpriam seu papel. As charges e caricaturas retratavam figuras importantes da sociedade e outras formas de ilustração andavam de mãos dadas com os textos jornalísticos.

A reportagem sobre sua segunda visita à Faixa de Gaza no formato de HQ permitiu que Sacco mostrasse outra faceta da Palestina. Em Notas sobre Gaza (2010), ele retrata principalmente memórias, lembranças e entrevistas relativas a acontecimentos do passado. Concentra-se em coletar dados e informações sobre os ataques em Rafah e Khan Younis em 1956.

A necessidade de reportar histórias que estão situadas em um passado tão distante é o que motiva Sacco a escrever este novo livro. A relevância de retratar o que se passou está no fato de que, para a mídia Ocidental, o fato passa despercebido. Sabese a mídia busca notícias importantes, bem como eventos de destaque, mas o massacre que aconteceu naquela região é relegado a notas em rodapés de livros de História.

Em sua resenha sobre Notas sobre Gaza para o The New York Times Book Review, Patrick Cockburn (2009) escreve que Sacco perpetua a sua obra devido ao "formato e estilos únicos em sua narrativa nos quadrinhos" ${ }^{23}$. O repórter-quadrinista consegue contar uma história misturando arte e jornalismo de ponta. A contribuição de Sacco para o jornalismo é real, uma vez que ele busca fatos de eventos esquecidos que semearam o ódio em muitos palestinos.

Para conseguir reconstruir e entender os conflitos que aconteceram em 1956 nas cidades de Rafah e Khan Younis, Sacco contou com o auxílio de pesquisadores

\footnotetext{
${ }^{23}$ Em inglês, "unique format and style of his comic-book narrative" Fonte: http://www.nytimes.com/2009/12/27/books/review/Cockburn-t.html?_r=0
} Acesso online em 20 de janeiro de 2016. 
israelenses. O questionamento constante do jornalista é que as informações em língua inglesa eram limitadas. Porém, ele conseguiu acesso a dados que estavam fechados ou eram classificados como confidenciais. Em uma entrevista para a revista online Believer, Sacco conta um pouco sobre as informações que conseguiu:

Li trechos do testemunho de Ben-Gurion, mas um dos meus pesquisadores israelenses encontrou um jornal que reimprimiu sua resposta completa ao incidente em Rafah. Em um livro de Chomsky, li um pedaço da história de Mark Gefen, o soldado que foi testemunha, o qual fala sobre um 'açougue humano'. Foi colocada como nota de rodapé em uma revista lá nos anos 80 . Alguém a encontrou, e então meu editor traduziu o documento todo para mim. Com certeza há algumas coisas novas neste livro. Gostaria que houvesse mais. (SACCO, 2011)

Os arquivos disponíveis nas Forças de Defesa Israelenses (FDI) estavam todos em hebraico. Para conseguir encontrar as pessoas que vivenciaram os conflitos em 56, Joe Sacco falou com militares, comandantes de brigadas, historiadores israelenses, e pessoas que eram citadas em diferentes jornais. Uma de suas preocupações sobre a documentação dos fatos e eventos que foram esquecidos na região é que há a necessidade de historiadores israelenses buscarem relatar esse período também. Segundo ele (idem), "Uma pessoa sozinha não pode escrever uma história desse tipo. Acredito que são necessários vários ângulos” 24.

\footnotetext{
${ }^{24}$ Em inlgês, "One person alone cannot write a history of this sort of thing. I think you need many angles". - Fonte: http://www.believermag.com/issues/201106/?read=interview_sacco Acesso online em 22 de janeiro de 2016.
} 


\section{CAPÍTULO 2 - REFERENCIAL TEÓRICO E MÉTODO}

Os Estudos da Tradução contam com diferentes teorias que são pertinentes a áreas específicas. Para este trabalho, as seguintes teorias da tradução servem como base teórica para análise da obra de Joe Sacco: aspectos de tradução de textos sensíveis com base na obra de Karl Simms, a tradução de ironia e alteridade, a Teoria do Escopo - de Katharina Reiss e Hans J. Vermeer, e a Teoria Funcionalista Moderna - de Nord, HQ, semiótica e transcriação, estratégias e procedimentos de tradução de Heloísa Barbosa.

\subsection{TEXTOS SENSÍVEIS}

A sensibilidade de um texto pode depender de fatores históricos ou culturais, mas muito mais pelo contexto da língua na qual está inserido. Para Simms (2006, p.3), "Esta sensibilidade pode ser de duas ordens: por causa das referências cujo conteúdo do texto o faz ser tabu, ou o próprio fato da existência do texto pode ser tabu" ${ }^{25}$. Um texto pode ser sensível por ter sido escrito por um autor ativista, ou por ter conteúdo considerado inapropriado ou tabu ${ }^{26}$, por exemplo.

O conteúdo é um dos elementos que fazem um texto ser considerado sensível. Simms faz a diferença entre conteúdo (content) e assunto (subject-matter). Um texto médico, por exemplo, pode ter sexo como o assunto principal e não ser considerado pornográfico. Além disso, é importante saber o contexto onde uma determinada frase está inserida. Uma mesma frase sobre sexo pode ser considerada sensível ou não de acordo com o contexto do texto e o contexto do receptor. Simms exemplifica que uma

\footnotetext{
${ }^{25}$ Em inglês, "This sensitivity may be of two orders: either the references which the content of the text makes are taboo, or the fact of the existence of the text as such may be taboo".

${ }^{26}$ De acordo com Simms (2006), o ensaio "Uma boa xícara de chá", de George Orwell, foi banido em vários países porque ele era considerado um autor proibido e o livro "O amante de Lady Chatterley", de D.H. Lawrence, foi banido por causa de seu conteúdo.
} 
mesma frase sobre sexo em um texto de medicina é compreendida de forma racional, porém, se inserida num contexto de pornografia, o texto poderia ser considerado ofensivo. Dentro do âmbito do texto pornográfico, ainda assim, o receptor poderia não achar o texto sensível, mas a sociedade na qual ele está inserido, sim.

Então, a sensibilidade dependeria de quem está lendo o texto. Uma pessoa não vive em só um meio social, mas participa de várias esferas. De acordo com Simms,

O fato é que as pessoas não pertencem simplesmente a uma comunidade pela qual podem ser definidas (ele é médico, ela linguista), mas vivem por meio comunidades de relações, traçando caminhos por elas que de tempos em tempos cruzam com outros caminhos de relações com outros indivíduos (SIMMS, 2006, p.4) ${ }^{27}$.

A questão se um texto é sensível não é sempre algo compreendido de forma clara. Não se pode dizer de forma "objetiva" que um texto é ou não sensível, porém também não se pode dizer que é algo "subjetivo" que depende da visão de um indivíduo. Além disso, “a percepção de um texto como 'sensível' pode mudar com o tempo" (idem, p.5). Não só a percepção, como também a natureza da sensibilidade pode ser compreendida de uma maneira diferente com o passar do tempo e de lugar para lugar 28 .

É possível ver que a sensibilidade tem várias facetas que fazem com que um texto admita diferentes níveis de sensibilidade. Simms delimita quatro áreas que são tradicionalmente sensíveis: textos contrários ao estado, à religião, à decência ou a cidadãos específicos.

Na tradução, é necessário interpretar o texto. Mesmo em casos de tradução intralingual é necessário que a interpretação, no sentido da hermenêutica, ocorra para auxiliar na decisão de uma palavra pela outra (ibid.). O fato de traduzir uma determinada cor em um verso de uma poesia, por exemplo, âmbar ao invés de amarelo,

\footnotetext{
${ }^{27}$ Em inglês, "The fact is that people do not simply belong to one community by which they may bedefined (he's a doctor, she's a linguist), but rather live through networks of communities, tracing paths through them which from time to time cross the networking paths of other individuals".

${ }^{28}$ Durante muito tempo Sade foi considerado obsceno, outros livros com conteúdos sexuais ou políticos também foram proibidos.
} 
indica a escolha devido o registro ser poético. A referência à cor permanece, mas a intensidade muda, afetando, assim, o tom do texto.

No âmbito da tradução interlingual, no entanto, isto é muito mais subjetivo; o "tom é um efeito subjetivo contingente e dependente na psicologia individual de quem ouve a palavra, expressão ou frase em questão ${ }^{29 "}$ (idem, p.6). O aspecto subjetivo do tom de um texto somente será identificado se o tradutor tiver experiência, ou seja, isto depende do conhecimento implícito para saber como certa intensidade seria usada para expressar uma referência necessária. Por exemplo, usar a palavra "índigo" ao invés de "azul" fora do contexto poético pode ser considerado artificial ou irônico. Deve-se ter em mente que a tradução interlingual "é impossível em sua forma pura, uma vez que não há algo como um sinônimo puro dentro de uma língua, então não há algo como uma equivalência lexical pura entre as línguas ${ }^{30 "}$ (ibid.).

A tradução não deve ser compreendida como algo que é inatingível, imperfeita ou impossível. Textos são traduzidos diariamente independentemente do conceito que uma tradução pura nunca será alcançada. Os sistemas linguístico-culturais das línguas envolvidas em uma tradução mostram que pode haver uma aproximação e que as formas de se dizer algo podem ser diferentes ou similares.

Textos sensíveis apresentam diversas características que podem passar despercebidas. Porém, o tradutor deve buscar ter conhecimento prévio de ambas as línguas dentro dos contextos de cada conjunto de língua-cultura. Há modos de sensibilidade que podem afetar a realização de uma tradução, são elas: a) alteridade: raça, etnicidade, cultura; b) instituições: política, estado, lei; c) textos sagrados, e d) textos profanos.

“Toda tradução é uma tradução entre culturas 31 ", sendo assim, o tradutor tem que reconhecer as sensibilidades culturais. A maneira como se nomeiam cores varia

\footnotetext{
${ }^{29}$ Em inglês, "tone is a subjective effect contingent and dependent on the individual psychology of whoever happens to be hearing the word, expression or sentence in question"

${ }^{30}$ Em inglês, "is impossible in a pure form, since just as there is no such thing as pure synonymy within a language, so there is no such thing as pure lexical equivalence between languages".

${ }^{31}$ Em inglês, "Any translation is a translation between cultures" (idem, p.10)
} 
com a realidade dos indivíduos de uma determinada esfera, podendo assumir outros nomes de acordo com a intensidade claro-escuro e a característica fresco-seco, como na cultura Hanunóo ${ }^{32}$. A língua de sinais é mais gráfica devido a sua natureza e as características visuais tendem a serem usadas para denominar algo ou alguém; se um indivíduo usar óculos, ou tiver o nariz grande, ele receberá um sinal para ser identificado como "pessoa que usa óculos" ou "pessoa com o nariz grande". Entretanto, ao se traduzir sinais de identificação para outra língua, a sensibilidade pode aparecer devido à lógica e convenção da outra língua.

\subsection{A TRADUÇÃO DE IRONIA}

A ironia é um dos elementos presentes nos quadrinhos de Joe Sacco. Ele utiliza a ironia como um recurso para levar o leitor à reflexão. Em determinados momentos ele a utiliza no discurso escrito, em outros ele reproduz uma ironia visual. A incongruência entre o dito e o não dito é o que leva ao efeito irônico. Deixa-se implícito em um enunciado algo não dito. Na perspectiva de Muecke, a ironia ativa não somente o contrário do que se quer dizer; ativa infinitas interpretações (MAHER, 2015, p. 232).

Santos (2008, p.29) explica que a ironia na visão de Hutcheon envolve três características: relacional, incluso e diferencial. Quando desempenha o caráter relacional, a ironia passa entre os significados ditos e não ditos, resultando na "criação de um novo sentido". O caráter incluso da ironia "está relacionado ao caráter de fixidez". Para se alcançar o sentido irônico não é necessário optar pela literalidade ao invés do sentido figurado. Quando diferentes elementos que compõem os significados ditos e não ditos, o caráter diferencial acontece, resultando em um efeito irônico.

No âmbito literário, a ironia é considerada

\footnotetext{
${ }^{32}$ Uma das línguas faladas nas Filipinas em uma tribo de 13.000 falantes. https://www.ethnologue.com/language/hnn
} 
como um procedimento de constituição do sentido que visa à desmistificação da aparência que se demonstra enquanto realidade. $\mathrm{O}$ que é dito deixa marcas textuais ou contextuais para um não dito em potencial. $\mathrm{O}$ dito e o não dito, sendo simultâneos e diferentes, se relacionam entre si para construir o efeito irônico em um contexto determinado e levando-se em conta as atitudes e expectativas do ironista e intérprete para com a vítima (SANTOS, 2008, p.30).

Pode-se chegar à compreensão da ironia por dedução. Ao substituir um significado explícito por um implícito, a ironia é revelada pela relação de contradição. Para Castro (1990 apud Santos, 2008), "Essa postura teórica faz com que o texto irônico seja compreendido como resultado de uma operacionalização dedutiva de contradição ou contrariedade através do qual se obtém o pressuposto enquanto expressão verdadeira de significação". Por exemplo, "um dia belo" prevê a contradição "um dia não belo" evocando, dessa maneira, o seu pressuposto, "um dia feio". O sentido literal remete ao sentido figurado. O pressuponente substitui o pressuposto. Assim, o falante consegue transmitir a ironia por meio da contrariedade.

O conflito entre aparência e realidade, o dito e o não dito, são algumas das formas que a ironia é produzida. Ela "é um processo semanticamente complexo que relaciona, diferencia e combina o dito e não dito para produzir outro sentido, levando em conta o contexto de produção, as atitudes e expectativas do ironista e intérprete" (HUTCHEON, 1994 apud SANTOS, 2008, p. 28).

A materialidade da ironia pode ser indicada de forma textual ou contextual. Essas marcas direcionam o leitor a interpretar a ironia onde ela está marcada (marcas textuais) e onde não está marcada (marcas contextuais). Mateo, em A tradução da ironia, explica que os sinais de ironia podem estar presentes no contexto, acompanhando o texto ou mesmo parte do texto. Ela diz: "Em outras palavras, os sinais podem estar no contexto (valores comuns informam a vítima de que o ironista 'não pode estar falando sério') ou podem acompanhar o texto (gestos...) ou ser parte do texto em si” (MATEO, 2010, p.199).

Há diversos fatores que contribuem para a complexidade em uma ironia. No processo de tradução, os elementos ditos remetem aos não ditos, permitindo "uma variedade de interpretações subversivas que constitui, por conseguinte, o efeito irônico" (SANTOS, 2008, p.42). É necessário compreender que a ironia precisa de criatividade e 
cuidado ao ser traduzida, pois o efeito irônico deve ser recriado na língua de chegada para que o leitor entenda as nuances e interpretações presentes no enunciado. Assim, “o processo de recriação da ironia pressupõe, por exemplo, o uso correto de uma palavra, a alteração da ordem sintática de uma sentença, a escolha incomum de uma colocação entre outros" (ibid).

Os fatores significativos no texto fonte que contribuem para a ironia devem ser reproduzidos, sempre que possível. A ambiguidade, o tom e o estilo do original devem ser mantidos pelo tradutor quando forem relevantes e colaborem para a construção do efeito irônico. Quando não for possível manter esses fatores, os procedimentos de tradução devem provocar o "efeito equivalente", ou seja, adaptar a ideia ou intenção da mensagem do original para que o leitor desfrute a ironia dentro da sua cultura (MATEO, 2010, p.206).

\subsection{TRADUÇÃO E ALTERIDADE}

Durante muito tempo se pensou que livros sagrados, poesia, escritos eróticos e outros textos não pudessem ser traduzidos. No entanto, a intraduzibilidade se mostra um conceito que é confrontado dia após dia, visto que textos sacros e profanos são traduzidos, bem como poemas. Entende-se que a tradução não está presente em uma determinada abordagem, pois no decorrer da História ela se fez presente de diversas maneiras.

A tradução, para Goethe, tem duas máximas: o autor vai ao encontro do leitor ou o leitor se sujeita ao estrangeiro; ambas têm suas vantagens. O texto pode ser recriado dentro do universo do leitor do texto traduzido ou pode manter sua identidade e alteridade para que o leitor conheça o sistema do qual os leitores do texto de partida fazem parte. Dentro dessas duas possibilidades, Goethe discorre que há três tipos de tradução - a tradução que "nos apresenta o estrangeiro à nossa maneira", a tradução que 
transpõe "as condições do estrangeiro, mas na verdade, apenas para se apropriar do sentido desconhecido e constituí-lo com sentido próprio" e a tradução que busca "tornar a tradução idêntica ao original, não de modo que um deva vigorar ao invés do outro, mas no lugar do outro" (GOETHE, 2010, p.29).

Essas três vertentes indicam a importância de como a tradução pode se apresentar para o leitor. Os enfoques variados expõem as características da relação do texto de partida com o texto de chegada, a visibilidade do tradutor, o projeto de tradução e demais fatores que são pertinentes ao processo tradutório.

\subsubsection{A alteridade na tradução de quadrinhos}

As línguas, com suas próprias especificidades, fazem parte de indivíduos, grupos, comunidades e sociedades. As sociedades se distinguem dentro de seus próprios núcleos culturais. Sendo assim, diferentes culturas compõem uma mesma sociedade com características diversas. As barreiras entre diferentes sistemas linguístico-culturais são transponíveis por meio da tradução. Segundo Pontes Jr e Batalha (2004, p.28), "É a tradução que introduz o 'outro' em sua forma mais radical e estranha: a linguagem”. Diferentes modos de dizer, sentir, expressar-se transparecem em linguagens diferentes. A tradução aproxima o desconhecido e nos leva a refletir sobre a nossa própria cultura, tradições e costumes e como lidamos com o estrangeiro.

Assim, a traduzibilidade desempenha um papel importante no conhecimento e troca de experiência com o outro. Para Pontes Jr e Batalha,

A traduzibilidade - expressão das diferentes maneiras através das quais a alteridade se manifesta - cria uma via de mão dupla entre as culturas, já que a alteridade só é compreensível se tomarmos a nossa própria cultura como base e esta, por sua vez, se modifica no contato com o outro. É a negociação permanente entre estranhamento e familiaridade, entre desconhecido e conhecido que representa, em última instância, o modo pelo qual os sistemas culturais se organizam e se movimentam. (idem, pp. 34-35) 
A reflexão com o encontro do exótico leva a uma ponderação sobre a tradução como um espelho que mostra a alteridade de forma clara ou distorcida. Ela propicia um encontro com uma multiplicidade de novas informações sobre algo que era desconhecido até ser traduzido. Por meio do processo tradutório, novos horizontes podem ser alcançados. Assim, os objetivos da análise crítica da tradução pode revelar muito mais do que conhecimento sobre outros povos e culturas; ela revela ideologias, relações de poder, políticas, níveis e modos de sensibilidade, outros pontos de vista, diferentes propósitos e intenções do texto traduzido.

A presença da alteridade é de extrema importância, pois ela, através da interpretação do texto, coloca ferramentas que são fundamentais para estabelecer diálogos, criar novas inferências, questionar posicionamentos e proporcionar um relacionamento mais profundo com o outro.

No jornalismo em quadrinhos, o exótico é expresso, principalmente, por aspectos visuais que demarcam cultura, costumes, vestimentas, comidas, regiões e arquitetura. É possível demonstrar visualmente marcadores culturais, como roupas, gestos, expressões faciais, detalhes sobre a região e arquitetura e outras Na tradução de jornalismo em quadrinhos, a alteridade aparece em várias instâncias: no meio escolhido, na temática, no estilo do autor e na tradução. A tradução como prática da alteridade cruza caminhos, instaura comunicações e abre oportunidades para a reflexão da reconstrução do texto em outra língua. 


\subsection{HQ, SEMIÓTICA E TRANSCRIAÇÃO}

As HQs têm uma linguagem específica que fazem com que sejam reconhecidas por seus leitores e usadas em diferentes meios de comunicação. Devido à linguagem específica dos quadrinhos, há predominância dos aspectos visuais sobre os verbais. Sendo assim, as HQs são, sobretudo, textos visuais “(compostos pelos desenhos, chamados de signos icônicos), que podem ou não incluir componentes verbais (as palavras, chamadas de signos simbólicos)" (LIBERATTI, 2012, p.50). Nos quadrinhos, a imagem se funde com os elementos linguísticos; assim, formando um único código. $\mathrm{O}$ código imagético e o código verbal assumem uma relação de alternância e complementaridade $^{33}$, as HQs são repletas de signos visuais e verbais, tornando a leitura dinâmica e rica.

A alternância e a complementariedade entre os elementos verbovisuais necessita de uma compreensão sob o ponto de vista da semiótica. São de grande importância os signos visuais e os verbais para entender o papel e a influência que têm para o entendimento da narrativa de forma absoluta. Depois de identificar a relevância dos signos icônicos e simbólicos é fundamental para elaborar uma tradução que não provoque dissonância no discurso escrito do texto de chegada.

O signo verbal pode representar um objeto para o intérprete de uma cultura e outro objeto diferente para outro intérprete. Deve-se prestar atenção a esses fatores e detalhes, pois eles podem ser vinculados diretamente à imagem, provocando um desafio ao tradutor. De acordo com Santaella:

O signo é múltiplo, variável e modifica-se de acordo com o olhar do observador [...] mas é preciso lembrar que o signo tem uma autonomia relativa em relação ao seu intérprete. Este apenas atualiza alguns níveis de um poder que já está no signo (SANTAELLA, 2005, p.45).

\footnotetext{
${ }^{33}$ As HQs podem contar histórias sem signos verbais; podem ter informações irrelevantes no âmbito da imagem. Porém, geralmente se tem uma relação de co-dependência. Em determinados momentos, elas assumem predominância; em outros, elas assumem o papel de complementar à narrativa da outra.
} 
Os signos presentes em textos com informações verbovisuais tendem a aparecer em um dos sistemas ou nos dois. A visualização da metáfora ou do símile pode ocorrer no plano do discurso escrito, bem como na visualização da imagem. Por exemplo, se um personagem tem uma ideia, ele pode expressar dizendo: “Tive uma ideia!”, o que comumente acontece no âmbito de quadrinhos é a concretização dessa oração na forma visível por meio de uma lâmpada piscando acima da cabeça do personagem, ou se estiver passando mal sentir a cabeça rodando (com auxílio de linhas cinéticas), se houver algum encontro amoroso, corações suspensos no ar, etc. (ECO, 1979, p.144). Assim, os signos icônicos e simbólicos formam um casamento de informações e interpretações que são transmitidas de uma maneira diferente de outros gêneros.

A imagem permite que outros elementos possam ser veiculados. A palavra permite que a ligação com a imagem seja de reconhecimento e complementação. $\mathrm{O}$ uso de onomatopeias abrange os dois códigos, visto que a representação do som por meio de palavra cria a associação com o discurso escrito e oral. Assim, não é possível dissociar um signo do outro, pois os dois estão intimamente ligados com a forma, representação e convenção. Dentro do possível, o tradutor traduz os elementos verbais da onomatopeia e ela é mantida como representação gráfica na obra traduzida.

A literatura sobre a tradução de quadrinhos ainda é limitada e se resume a

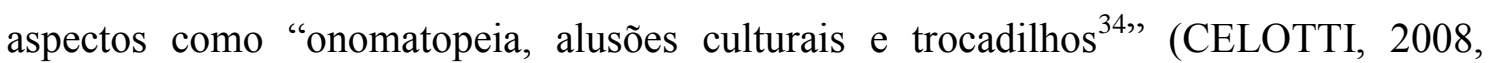
p.33). Quando estudada de forma mais profunda, as análises ficam confinadas em séries específicas, como por exemplo: Asterix e Tintim ${ }^{35}$. No Brasil, as pesquisas se concentram em quadrinhos amplamente conhecidos, como Mafalda, A turma da Mônica, Calvin e Haroldo, entre outros. Entretanto, novas pesquisas sobre a relaçãoimagem texto, aspectos históricos e intertextuais têm contribuído para os Estudos da Tradução no âmbito dos quadrinhos.

A presença da imagem em textos multimodais implica em níveis de interpretação por parte do tradutor, a fim de realizar uma tradução que seja completa.

\footnotetext{
${ }^{34}$ Em inglês: "onomatopoeia, cultural allusions and puns"

${ }^{35}$ No livro "Comics in Translation", há uma bibliografia anotada com 149 artigos publicados acerca da tradução de quadrinhos, sendo 42 sobre Astérix e dez sobre Tintim; é um volume extraordinário se comparado com artigos de outras HQs.
} 
Entretanto, a riqueza de uma narrativa sequencial pode ajudar o tradutor com informações visuais, mas ao mesmo tempo impor limitações e obstáculos para o tradutor de quadrinhos. A presença de ilustrações exige mais criatividade do tradutor. Em entrevista com Alexandre Boide (ver Anexo 2), tradutor de Notas sobre Gaza no Brasil, foi-lhe perguntado sobre essa limitação. Ele acredita que a imagem "limita a margem de adaptação possível naquele contexto, o que não ocorre com o texto não ilustrado".

Além desses aspectos, o tradutor deve estar atento ao espaço limitado nas legendas e recordatórios e balões (de fala, pensamento, etc.). De acordo com Boide, isso ocorre "para a tradução não ficar muito maior que o texto original, pois nesse caso acaba não cabendo no espaço delimitado. Na obra de um autor como Joe Sacco, manter a concisão é fundamental" (ver Anexo 1).

Além disso, Rosa afirma que.

$$
\begin{aligned}
& \text { na tradução de histórias em quadrinhos, sendo o texto parte da própria } \\
& \text { imagem, faz-se necessário que outros fatores sejam levados em consideração } \\
& \text { na leitura e apreensão de significado pelo tradutor, tais como forma e } \\
& \text { tamanho dos balões, que trazem significados próprios (ROSA, 2010, p.418). }
\end{aligned}
$$

Os aspectos verbais e não verbais presentes nos quadrinhos devem ser levados em consideração na tradução de quadrinhos, porém o tradutor precisa estar apto a fazer alterações no texto verbal em vista das informações não verbais. Com a finalidade de manter a harmonia entre os elementos verbais e visuais, o tradutor pode interferir no texto para fazer adaptações que não contradizem a imagem, uma vez que as imagens não são alteradas ${ }^{36}$.

A tradução de quadrinhos não pode ser focada somente no texto, uma vez que as informações visuais fazem parte da narrativa. $O$ tradutor não pode menosprezar o texto em função da imagem, nem a imagem por causa do texto, uma vez que a leitura de quadrinhos é realizada a partir da convergência das informações textuais e visuais.

\footnotetext{
${ }^{36}$ De acordo com Celotti (2008), há algumas convenções feitas por países sobre os aspectos que são aceitáveis ou não, como por exemplo o cigarro de Lucky Luke que foi alterado para um graveto em publicações na Suécia e em outros países.
} 
O tradutor busca traduzir todas as informações presentes no texto escrito em uma HQ, mas nem todas as informações serão traduzidas. Para Celotti (2008, ver p.), há quatro áreas que têm a predominância de mensagens verbais, sendo elas: os balões - que apresentam o maior volume de textos escritos que indicam falas, os recordatórios ou legendas - que indicam o tom narrativo dos quadrinhos com mudança de tempo e espaço, assim como comentários, os títulos - que chamam a atenção do leitor para uma nova jornada, aventura ou história e os paratextos linguísticos - que são as informações dentro dos desenhos, como mapas, jornais, sinalizações, onomatopeias, etc.

A tradução de uma HQ é feita de uma forma bastante específica, pois diferente da tradução de outros gêneros, ela é feita conforme os elementos verbais explícitos no texto. Assim, a tradução é enumerada e marcada em um arquivo separado. A inserção das escolhas não é colocada imediatamente dentro da narrativa sequencial. Boide, o tradutor de Notas sobre Gaza, explica que a tradução de HQ ocorre de forma diferente de outros gêneros. Segundo ele (Anexo 1):

Como não se trata de um texto corrido, é preciso entregar o arquivo todo numerado, separando o texto de boxes e balões de acordo com a ordem de leitura. Exemplo:

$<$ Página 3>

\section{<1> UM FIO DE ESPERANÇA}

$<2>$ Com certeza, meu amigo Mark tinha se dado bem. $<3>$ VOCÊ SE DEU BEM!

$<4>$ Um trabalho bem pago de jornalista para a ONU!

O tradutor manipula o texto em virtude da linguagem quadrinhística e busca manter as informações extratextuais no discurso escrito, como o uso elementos suprassegmentais (letras maiúsculas, negrito, sublinhado e itálico). O processo de tradução, então, passa por diversos passos. Desde a preparação do texto, até a diagramação final.

As HQs apresentam desafios para o tradutor, pois a imagem tende a ser inalterada e a impossibilidade de recriação do texto vinculado à imagem pode restringir as alternativas na língua de chegada. Entretanto, essas informações verbais são traduzidas independentemente das dificuldades impostas pelo meio de veiculação da 
história. O tradutor tem como meta atingir os objetivos fixados no projeto de tradução. Assim, ele consegue expressar na língua de chegada o espírito do texto de partida de acordo com as diretrizes estabelecidas. Busca-se revelar, da melhor maneira possível, a essência do texto original (estilo do autor, sensibilidade, jogos de palavras, contexto cultural, histórico e político) para leitores de outra língua.

O código visual impõe seus limites, porém o conceito de intraduzibilidade do código verbal é desconstruído, uma vez que o tradutor se empenha em traduzir o que não se pode traduzir. A tradução vai além dos limites impostos pelos elementos verbovisuais; ela transcria sensações, mimetiza estilos e alcança a harmonia entre ambos os códigos. O objetivo de toda arte é considerado impossível; entretanto, os artistas tornam a arte possível de diversas maneiras. Como dizia Rónai,

O objetivo de toda arte não é algo impossível? O poeta exprime (ou quer exprimir) o inexprimível, o pintor reproduz o irreproduzível, o estatuário fixa o infixável. Não é surpreendente, pois, que o tradutor se empenhe em traduzir o intraduzível (RÓNAI, 1987, p.14).

A tradução de um texto não deve ser pensada de forma isolada. As palavras são parte da trama da tessitura narrativa. $\mathrm{O}$ gênero, o tema e o contexto envolvidos devem guiar a significação das palavras no texto traduzido. Para Rónai (idem, p. 13) "todo texto literário é fundamentalmente intraduzível por causa da própria natureza da linguagem". Entretanto, as palavras soltas "não têm sentido em si mesmas: a sua significação é determinada pelo respectivo contexto". Os elementos isolados são desconexos e separam a compreensão da totalidade do texto. Deve-se procurar a intenção das palavras a fim de que o sentido seja transmitido ${ }^{37}$. O tradutor é incumbido da tarefa de "encontrar na língua para a qual se traduz a intenção a partir da qual o eco do original é nela despertado" (BENJAMIN, 2011, p.112).

Então, a busca por um equivalente perfeito deve ser descartada, pois a construção, a identidade e a história de uma língua diferem da outra. O conceito, o

\footnotetext{
37 A afinidade entre as línguas se encontra na pura língua/linguagem, na complementaridade das intenções das línguas do original e da tradução. Benjamin, em A tarefa do tradutor, (2010, p.213) explica, "Pois enquanto todos os elementos isolados - as palavras, frases, nexos sintáticos - das línguas estrangeiras se excluem, essas línguas se complementam em suas intenções mesmas”.
} 
sentido ou a essência da palavra deve ser extraído, para assim, encontrar a forma de expressar na outra língua. Ao invés de se pensar a tradução meramente como uma forma de encontrar equivalentes em outra língua, seria adequado pensar no querer dizer na tradução, e não no modo, a fim de que haja uma compreensão das diferenças entre os mundos que cada língua representa.

A tradução não desempenha um papel de simplesmente encontrar palavras exatas no texto da língua de chegada, e sim recriar a maneira de se dizer considerando o terreno singular que a tradução adentra. Nas HQs, a tradução deve levar em consideração não somente os signos verbais da língua estrangeira, como também signos visuais que fazem parte da linguagem dos quadrinhos.

A interpretação da obra como um todo é de extrema importância para o processo tradutório. A tradução escrita não é um ato mecânico que dispensa a reflexão. Para Gadamer (2010, p.241), "a tradução de um texto (...) não é um simples redespertar do processo psicológico original da escrita, mas uma recriação do texto, guiada pela compreensão do que está dito nele". A recriação pressupõe a interpretação do texto por parte do tradutor a fim de que ele reconstrua o texto no contexto de chegada. Assim, os conceitos de tradução como recriação ou transcriação são adequados para a tradução de textos criativos. Para Campos,

Então, para nós, tradução de textos criativos será sempre recriação, ou criação paralela, autônoma, porém recíproca. Quanto mais inçado de dificuldades esse texto, mais recriável, mais sedutor enquanto possibilidade aberta de recriação. Numa tradução dessa natureza, não se traduz apenas o significado, traduz-se o próprio signo, ou seja, sua fisicalidade, sua materialidade mesma (propriedades sonoras, de imagética visual, enfim tudo aquilo que forma, segundo Charles Morris, a iconicidade do signo estético, entendido por signo icônico aquele 'que é de certa forma similar àquilo que ele denota'). $\mathrm{O}$ significado, o parâmetro semântico, será apenas tão-somente a baliza demarcatória do lugar da empresa recriadora. Está-se pois no avesso da chamada tradução literal. (CAMPOS, 1992, p. 35 apud PEREIRA, 2004)

Geronimo (2010) explica que "na tradução transcriadora é necessário levar em consideração o texto como um todo, pois a forma como ele está constituído também implica na constituição do sentido". O sentido pontual de uma palavra é abandonado na reconstrução do texto, pois o sentido se encontra na totalidade do texto. A busca da 
reconstrução dos signos vai além da imagem do significado, "acende a 'imagem do seu significante', da sua 'forma significante'” (ibid).

\subsection{O FUNCIONALISMO ALEMÃO: TEORIA DO ESCOPO E TEORIA FUNCIONALISTA DE NORD}

\subsubsection{A Teoria do Escopo (Skopostheorie)}

A tradução de um texto envolve vários aspectos linguístico-culturais inerentes à cultura de partida. A ação de transportar um texto de um sistema linguístico para outro não é uma tarefa fácil. Porém, devem-se levar em consideração ambos os sistemas (de partida e de chegada) e como, e de acordo com quais ações o texto de partida é continuado (traduzido). Sendo assim, "uma ação translativa é governada por seu propósito" (REISS e VERMEER, 2013, p.85) ${ }^{38}$.

A finalidade é o objetivo principal de uma tradução feita de acordo com as ações translativas. O escopo de uma ação está intimamente ligado à forma que essa ação é

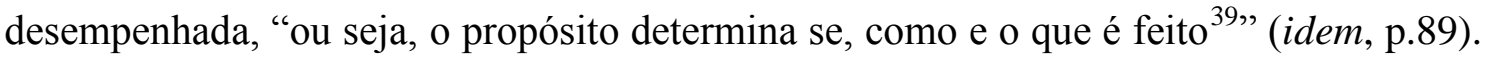
Os textos apresentam vários escopos, sendo, assim, necessário determiná-los para que as ações translativas alcancem os objetivos de tornarem o texto funcional para o público de chegada. De acordo com Reiss e Vermeer (idem, p.90), "Não há algo como 'a' tradução de um texto. Os resultados do processo de tradução irão variar de acordo com seus escopos ${ }^{40}$,

Segundo Liberatti (2013, p.67),

\footnotetext{
${ }^{38}$ Em inglês: "A translational action is governed by its purpose."

${ }^{39}$ Em inglês: "i.e. the purpose determines whether, how and what is done."

${ }^{40}$ Em inglês: "There is no such thing as 'the' translation of a text; the results of the translation process will vary according to their skopoi."
} 
Vermeer defende que toda tradução possui um objetivo (skopos: palavra grega que significa propósito), e as escolhas tradutórias são determinadas pelo propósito comunicativo almejado pelo cliente (por exemplo: vender, instruir, convencer, etc.).

Assim, o texto traduzido sempre será determinado conforme os propósitos selecionados para a tradução, não só pelo tradutor, mas pelo cliente ou editora. A crença de que só uma tradução é possível ou adequada é desmistificada com a teoria de Reiss e Vermeer, uma vez que a tradução gira em volta dos propósitos definidos. A fidelidade não está vinculada ao texto fonte, mas sim aos propósitos e à função que o texto traduzido virá a desempenhar.

O processo de tradução sob a ótica dessa teoria é divido em três fases: a determinação do escopo, a redefinição da relevância de alguns aspectos do texto-fonte de acordo com o escopo estabelecido e a realização do escopo. Na primeira fase, definese quem é o público-alvo, para saber se uma determinada função faz sentido para eles. Na segunda fase, há a decisão se a redefinição deve ser feita antes, durante ou depois do ato tradutório. Na terceira fase, leva-se em consideração a expectativa do público-alvo de acordo com os critérios estabelecidos nas fases anteriores (idem, p.92).

\subsubsection{A Teoria Funcionalista de Nord}

A Teoria Funcionalista de Nord surge a partir da Skopostheorie. Ela retoma os conceitos básicos da teoria fundamentada por Reiss e Vermeer e os sistematiza em: skopos, objetivo, propósito, intenção, função e diretrizes de tradução. Além disso, seu modelo apresenta um nível mais profundo no âmbito da coerência intratextual e intertextual. O modelo de análise textual proposto por Nord apresenta três objetivos: a oferta de informações que contribuem para a compreensão e análise do texto-fonte, a oferta de critérios informativos acerca das estratégias tradutórias - a partir do texto-alvo - e a oferta de critérios que permitem a avaliação do texto-alvo (LIBERATTI, 2013, p.68). 
Para mais bem compreender como o funcionalismo de Nord se estrutura, é necessário entender que as ações ou atividades humanas são desempenhadas por “agentes". Esses agentes são indivíduos que desempenham papéis, de remetente ou de receptor. Sendo assim:

Ao desempenhar o papel de remetentes na comunicação, as pessoas têm propósitos comunicativos que tentam colocar em prática por meio de textos. Os propósitos comunicativos têm como objetivo outras pessoas que desempenham o papel de receptores. Assim, a comunicação ocorre por meio de um meio de comunicação e em situações que são restringidas pelo tempo e lugar ${ }^{41}$. (NORD, 2005, p.18)

$\mathrm{Na}$ comunicação, as pessoas assumem papéis diferentes. Cada situação é determinada pelo papel que cada indivíduo tem. As situações não são fixas, nem universais. Elas estão intrinsecamente inseridas no âmbito linguístico-cultural. Uma ação comunicativa apresenta um complexo de restrições dentro do sistema cultural na qual está inserida, além do papel que cada interlocutor tem naquela situação específica. Uma mulher pode ser mãe ralhando com o filho ou chefe conversando com o subordinado, ou ainda uma fã admirando sua cantora favorita.

O propósito é fator determinante das escolhas de estratégias de tradução. Porém, a autora sugere que há distinção entre propósito, intenção e função (NORD, 1997, p.28). O remetente é o responsável por definir o propósito (skopos) e a intenção do texto de chegada, pois é ele que busca alcançar um determinado propósito com o texto. Já a função está a cargo do receptor. De acordo com Nord (idem),

os receptores usam o texto com uma determinada função, dependendo de suas expectativas, necessidades, conhecimento prévio e condições situacionais. Em uma situação ideal, a intenção do remetente irá ao encontro de seu objetivo, neste caso intenção e função seriam análogas ou até mesmo idênticas ${ }^{42}$.

\footnotetext{
${ }^{41}$ Em inglês: "When playing the role of senders in communication, people have communicative purposes that they try to put into practice by means of texts. Communicative purposes are aimed at other people who are playing the role of receivers. Communication takes place through a medium and in situations that are limited in time and place".

${ }^{42}$ Em inglês: "the receivers use the text with a certain function, depending on their own expectations, needs, previous knowledge and situational conditions. In an ideal situation the sender's intention will find its aim, in which case intention and function would be analogous or even identical"
} 
O texto desempenha uma função comunicativa "em que cada situação específica determina o que e como as pessoas se comunicam" (LIBERATTI, 2013, p.70). Assim, um texto traduzido, de acordo com os moldes funcionalistas, deve ser funcional para o leitor-alvo. A tradução seria "uma transferência não exclusivamente linguística, e sim uma transferência linguística e cultural" (idem).

Por meio de três funções da linguagem - referencial, expressiva e apelativa ${ }^{43}$ - é possível alcançar o propósito comunicativo do texto, "uma vez que a tradução é uma forma de interação que tem um propósito amplamente comunicativo" (ALMEIDA, 2015, p.28). Ao determinar o propósito da tradução é possível escolher os métodos e as estratégias tradutórias que servirão de auxílio no processo translacional; assim, o princípio da funcionalidade é alcançado.

Levando em consideração o funcionalismo da comunicação, é necessário abrir espaço para os elementos não verbais e os papéis que desempenham nos discursos oral e escrito. São utilizados para complementar a comunicação verbal e "compreendem os elementos paralinguísticos da comunicação face a face" (LIBERATTI, 2012, p.79). Por exemplo, gestos, expressões faciais e tom de voz influenciam na comunicação verbal. Já na comunicação escrita, esses elementos podem ser logos, sinais, fotos, ilustrações etc. Esses elementos intensificam a mensagem do texto, adicionam novas informações, ilustram novos sentidos e eliminam a ambiguidade.

Além dos elementos não verbais, as marcas de organização textual, ou seja, os elementos suprassegmentais são extremamente importantes para o texto, pois ultrapassam os "limites de segmentos lexicais ou sintáticos" dando o tom ao texto. Nos quadrinhos, essas marcas aparecem como pontuação, dando a ideia de pausas ou hesitação; letras maiúsculas, representando a entonação e outras marcações que imitam aspectos da comunicação verbal. Os elementos suprassegmentais nos quadrinhos são graficamente representados, usando a forma visual para reproduzir a sensação de algo

\footnotetext{
${ }^{43}$ São as funções da linguagem que determinam qual são as funções que um determinado texto tem. A função referencial privilegia o "referente da mensagem", busca "transmitir informações objetivas” . A função expressiva tem o foco no emissor, transmite o conteúdo de forma subjetiva. A função apelativa tem o foco no receptor, pois busca influenciar, convencer o receptor de algo. Fonte: http://brasilescola.uol.com.br/gramatica/funcoes-linguagem.htm Acesso online em 20 de abril de 2014.
} 
oral com sinalizações no texto escrito, como aspas, espaçamento, negrito, itálico, sublinhado, etc.

A função, o propósito e a intenção de um texto contribuem juntamente para o efeito que ele terá. Na visão funcionalista, o efeito está ligado ao receptor. Segundo Liberatti (2012, p.78), não se trata de algo direcionado a um dos extremos extra ou intertextual.

\subsection{ESTRATÉGIAS DE TRADUÇÃO}

A tradução envolve tanto teoria (implícita ou explícita) como prática. O tradutor usa estratégias e procedimentos tradutórios para atingir a finalidade do seu projeto para a língua de chegada. As estratégias de tradução indicam se o tradutor está mais perto do autor ou do leitor alvo. No âmbito da tradução funcionalista, o texto traduzido destinase a comunicar o texto original em língua estrangeira. Assim, alguns procedimentos de tradução serão evidenciados.

A tradução palavra por palavra é um procedimento que traduz um determinado segmento textual na língua fonte que mantém a mesma sintaxe e vocábulos correspondentes na língua alvo (BARBOSA, 2004, p.64). Por exemplo, "He painted the wall" pode ser traduzido por "Ele pintou a parede". Cada categoria é respeitada e os vocábulos mantêm a mesma semântica. Pode-se utilizar esse procedimento quando for possível, porém o uso é limitado, "pois é rara uma convergência tão grande entre línguas" (idem, p.65). Por causa da linguagem dos quadrinhos, este mecanismo será ainda mais restrito.

A tradução literal conserva a semântica dentro das normas gramaticais da língua alvo. Podem-se fazer alterações morfossintáticas para que o sentido permaneça no texto traduzido, como "It is a known fact" em português é traduzido por "é fato conhecido" (ibid). Não há a correspondência de "it" e " $a$ " dentro da sintaxe do texto de chegada. 
A transposição é um procedimento não obrigatório, pois ela permite mais de uma tradução para cada segmento. Ela "consiste na mudança de categoria gramatical de elementos que constituem o segmento a traduzir". Pode-se traduzir um advérbio por verbo reflexivo ou adjunto adverbial, por exemplo, "apologetically" por "desculpandose" ou "como justificativa" (idem, p. 66).

Em língua inglesa, é necessário usar a explicitação, por exemplo, de pronomes pessoais, visto que a sintaxe da língua não aceita que sejam omitidos. Porém, a omissão é bastante usada em língua portuguesa, pois certos elementos são repetitivos ou dispensáveis, como é o caso dos pronomes pessoais.

Quando não é possível reproduzir um efeito estilístico em um determinado momento do texto, o tradutor pode deslocar o recurso para outro ponto. A compensação permite que o estilo do autor seja recriado, evitando a perda estilística.

Em casos nos quais as línguas têm alfabetos diferentes, o texto precisa passar pela transliteração, que consiste em "substituir uma convenção gráfica por outra" (idem, p. 73). Por exemplo, "inshallah" passou uma transliteração do alfabeto árabe para o romano.

Para facilitar a compreensão de estrangeirismos, vocábulos ou expressões deixados na língua de origem, pode-se inserir a explicação. Esse procedimento visa eliminar problemas de entendimento no texto..

A adaptação é utilizada quando uma unidade de tradução "não existe na realidade extralinguística dos falantes da LT. Esta situação pode ser recriada por outra equivalente na realidade extralinguística da LT" (idem, p. 76).

Esses procedimentos são usados para alcançarem a reconstituição do texto na língua traduzida e podem ser utilizados em diferentes medidas de acordo com o projeto de tradução. Nos trechos selecionados para análise, as estratégias supracitadas indicam como diferentes nuances de sensibilidade, marcas de ironia, alteridade e estilo do autor foram recriadas no texto de chegada, preservando o conteúdo, transcriando a estilística do texto de partida. 


\section{CAPÍTULO 3 - ANÁLISE CRÍTICA DA TRADUÇÃo}

\subsection{AS DIFERENTES FACETAS DA SENSIBILIDADE}

As reportagens quadrinizadas de Joe Sacco mostram diferentes pontos de vista sobre realidades (normalmente) desconhecidas ou deixadas de lado. Com um olhar subjetivo sobre temas sérios e atuais, Sacco mostra, por meio de sua narrativa, um olhar novo e singular. Suas HQs exibem a natureza humana de outras nacionalidades em situações diversas. Desta maneira, ele expõe traços comuns e universais por meio do panorama criado em uma linguagem que abarca múltiplos relatos da sensibilidade. Ao usar elementos que denotam a ironia, a alteridade, a humanidade etc, o autor ressalta no texto original vários aspectos importantes que são fundamentais também na tradução.

\subsubsection{O papel do intérprete, tradutor e faz tudo}

Os textos multimodais, como as HQs, transmitem realidades que vão além da língua. Os quadrinhos conseguem se desprender do discurso escrito e mostram novas perspectivas interessantes sobre a língua (MAHER, 2015, p.228). Usando uma linguagem singular que mimetiza a realidade e reproduz uma visão pessoal, Sacco consegue demarcar em sua arte o que muitas vezes é ignorado.

De acordo com Maher (idem, p.222), “a natureza multimodal dos quadrinhos torna disponível uma gama de técnicas semióticas e narrativas interessantes para a 
representação de atos de mediação linguística e cultural ${ }^{44, "}$. O jornalismo em história em quadrinhos de Sacco redistribui e recodifica informações e fatos relacionados à palavra para o código visual (Figura 5). As imagens são significativas e importantes para a compreensão completa da obra nos quesitos social, cultural, relacional e profissional.

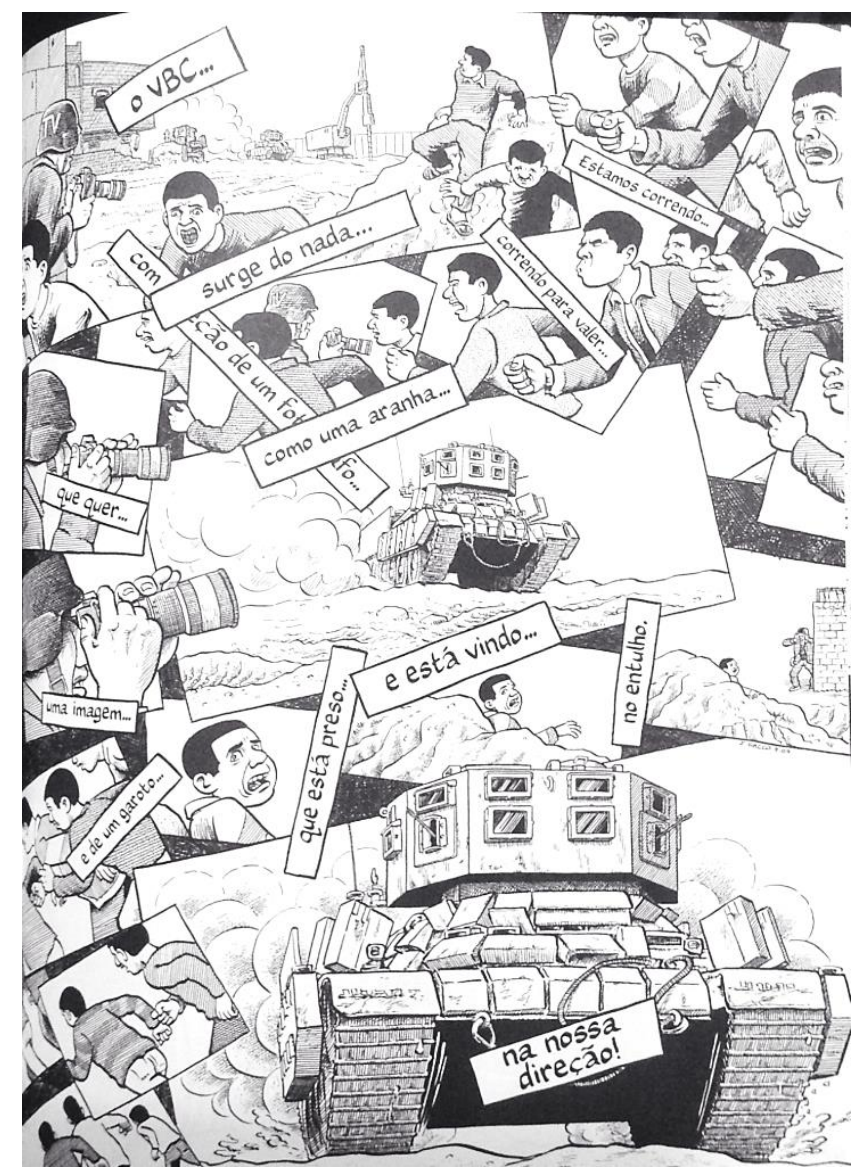

Figura 5. Tanque

Fonte: Notas sobre Gaza (SACCO, 2010, p.187)

Dentro da tipologia dos signos, há a espacialização icônica que faz parte da narrativa espacial. Nela, "há uma relação de semelhança entre o espaço daquilo que é narrado e o espaço interno desenhado pelos diagramas relacionais das sequências narrativas" (SANTAELLA, 2005, p. 327). Nos quadrinhos, a narrativa ocorre por meio da sequência de eventos presentes nos requadros. A relação de semelhança entre o

\footnotetext{
${ }^{44}$ Em inglês, "the multimodal nature of comics makes available a range of interesting semiotic and narrative techniques for the depiction of acts of linguistic and cultural mediation."
} 
discurso escrito e as representações gráficas permite com que a história adquira uma profundidade na narrativa.

A descrição dos tratores passando por Gaza e a posição das legendas tem um correspondência exata no âmbito da construção visual e linguística. $\mathrm{O}$ embaralhamento de palavras, imagens e demais elementos dos quadrinhos compõem um fluxo narrativo que reproduz o ícone (tremor) no texto multimodal. A desordem dos requadros e das legendas leva o leitor a ter a sensação de desespero e agitação no momento da cena narrada.

Uma das diferenças no trabalho do jornalista-cartunista é que ele explicita elementos da pesquisa e formas de entrevista que são ocultadas em outros meios de comunicação, como o papel do tradutor, as relações familiares, a realidade inconstante de zonas de guerra e o auxílio de agências e organismos internacionais.

A (in)visibilidade do tradutor é um tema recorrente nos Estudos da Tradução ${ }^{45}$. No meio jornalístico, prefere-se que as referências ao tradutor ou intérprete sejam deixadas de lado também. Maher (idem, p.224) explica que o papel do intérprete é como o de uma empregada doméstica; espera-se que o trabalho seja feito, mas ninguém quer que os outros saibam que ela está recebendo um salário baixo para deixar a casa limpa. Em outras palavras, não é interessante informar o público sobre o papel fundamental de um intérprete para que uma notícia seja transmitida ${ }^{46}$.

O trabalho de Sacco não é uma forma normal de jornalismo, uma vez que ele reconhece em seus quadrinhos que jornalistas internacionais dependem de seus intérpretes, não só no âmbito linguístico, mas também social, cultural e histórico para transitarem, conversarem e questionarem. Ao retratar situações com Abed, seu intérprete, ele chama a atenção do leitor para o fato de que jornalistas dependem constantemente de tradutores, intérpretes e guias locais. Assim, inserir Abed nas cenas funciona como um indicador de que as matérias e reportagens dificilmente seriam feitas se a barreira linguístico-cultural não fosse ultrapassada.

\footnotetext{
${ }^{45}$ Ver, por exemplo, VENUTI, Lawrence. The translator's invisibility: a history of translation. Londres e Nova York: Routledge, 1995)

${ }^{46}$ Daoud Hari, em seu libro $O$ tradutor (Rio de Janeiro: Rocco, 2008), mostra a realidade cruel de intérpretes em zona de guerra.
} 
No capítulo Todos nós vamos sofrer, o tema inicial da conversa com Hani é sobre um ataque suicida que não deixou muitas mortes de israelenses. Outros aspectos, além do assunto, aparecem no diálogo. Abed faz seu papel de intérprete e aparece "calado" durante a refeição. Sacco frequentemente desenha o intérprete, tradutor e "faz tudo" nas cenas com o propósito de representar a mediação de um diálogo. Ao invés de colocar a repetição "ele disse" para informar o discurso traduzido, o cartunista faz uso dos recursos dos quadrinhos e marca a presença visual de Abed em quase todas as situações de entrevista e coleta de dados (Figuras 5,6 e 7). 


\subsubsection{A alteridade em aspectos (extra)linguísticos}

Sacco, em sua narrativa, opta por mostrar aos leitores que a história se desenvolve em um ambiente difícil e de conflitos constantes, mas ao mesmo tempo há uma abundância de detalhes que abrangem a história, a língua e a cultura local por meio de um texto híbrido. No capítulo Os fedayeen, temos um título que traz um termo em língua estrangeira. Porém, em uma das legendas, entre o primeiro e segundo quadro, há o termo em árabe e a tradução, como forma de explicitação ${ }^{47}$, nos textos originais e traduzido. A palavra fedayeen no singular é fedayee e significa guerrilheiro ${ }^{48}$. Sacco e Abed entrevistam um "autêntico fedayee" que conta um pouco das atividades de seu grupo guerrilheiro na década de 50.

Na primeira página deste capítulo (SACCO, 2009; 2010, p.40), logo no primeiro quadro, o leitor é confrontado com uma cena de explosão de um carro; diversos figurantes estão em chamas. As sensações de medo, desespero e agonia são transmitidas pela imagem. O contexto da explosão é explicado por Sacco em uma legenda. Depois do ataque em uma noite de fevereiro em 1995, um grupo de guerrilheiros foi formado. Abaixo do título Os fedayeen, vemos o segundo quadro. O quadrinista chama o leitor para o tempo presente da narrativa. Passado e presente são ligados pela imagem. Sacco coloca no primeiro quadro um veículo pegando fogo e no segundo quadro uma fila de carros parados.

As informações transmitidas pelas cenas seguintes denotam as pessoas que conversaram com Abed e Sacco, as vestimentas típicas, e a transição de cidade para zona rural. A "dupla dinâmica”, jornalista e intérprete, passa de táxi em táxi à procura de alguém para levá-los até a próxima testemunha. As roupas do motorista não diferem

\footnotetext{
${ }^{47}$ Segundo Barbosa (2004,p.46), “A explicitação é [...] realizada para deixar claro que o leitor do TLT algo que não lhe é familiar na cultura do TLO.”

48 "Guerrilheiros árabes operando especialmente contra Israel” (Arab guerrillas operating especially against Israel) Fonte: http://www.oxforddictionaries.com/definition/english/fedayeen Acesso online em 20 de fevereiro de 2016.
} 
das usadas por Sacco e Abed, mas as roupas do passageiro, sim. Ele usa cafia ${ }^{49}$ e gal $^{50}$ na cabeça, peças típicas da região.

No terceiro quadro, Sacco e Abed conversam com um senhor que veste uma túnica, um paletó por cima e usa alguns adereços na cabeça - ghutra ${ }^{51}$ e igal, peças que também iconizamas roupas da região (Figura 6). O último quadro indica a passagem da cidade para o campo com a sinalização de uma estrada não asfaltada, poucos edifícios e alguns arbustos pelo caminho.

A representação fiel das situações que Sacco vivenciou, assim como as roupas tradicionais palestinas e os detalhes geográficos servem como um lembrete para o leitor que a voz da narrativa se encontra em solo estrangeiro. Apesar de narrar os fatos e eventos em inglês, o jornalista-cartunista faz questão de delimitar o local de fala com as características da sua visita à Gaza. Primeiro, ele introduz as marcas de alteridade de forma visual para seus leitores dos textos. Em seguida, deixa termos, expressões, feriados e outras palavras em árabe. Incorpora a língua estrangeira como elemento verbal, aproximando o leitor do sistema linguístico-cultural da sua reportagem.

\footnotetext{
49 A cafia ou keffiyeh "consiste em um pano quadrado preso por uma tira chamada egal". Além disso, a cafia é um tipo de pano de lã ou algodão que virou um símbolo do nacionalismo palestino, adotado por Arafat durante o movimento de resistência Palestina. Fonte: http://super.abril.com.br/cultura/quais-saoos-trajes-tipicos-dos-paises-islamicos-e-o-que-representam Acesso online em 20 de fevereiro de 2016.

${ }^{50}$ Igal (egal ou agal) é a ““cordinha’ preta de duas voltas. [...] A peça é feita de lã de camelo ou de ovelha, tramada para formar uma corda".Fonte: http://www.destinodubai.com.br/2015/08/19/entenda-a-roupausada-pelos-homens-arabes/ Acesso online em 20 de fevereiro de 2016.
}

${ }^{51}$ O guthra é um "tradicional lenço usado na cabeça. De formato quadrado e feito em algodão, ele é dobrado como um triângulo e colocado sobre o Gahfiya com a dobra na parte da frente". Fonte: http://www.destinodubai.com.br/2015/08/19/entenda-a-roupa-usada-pelos-homens-arabes/ Acesso online em 20 de fevereiro de 2016. 


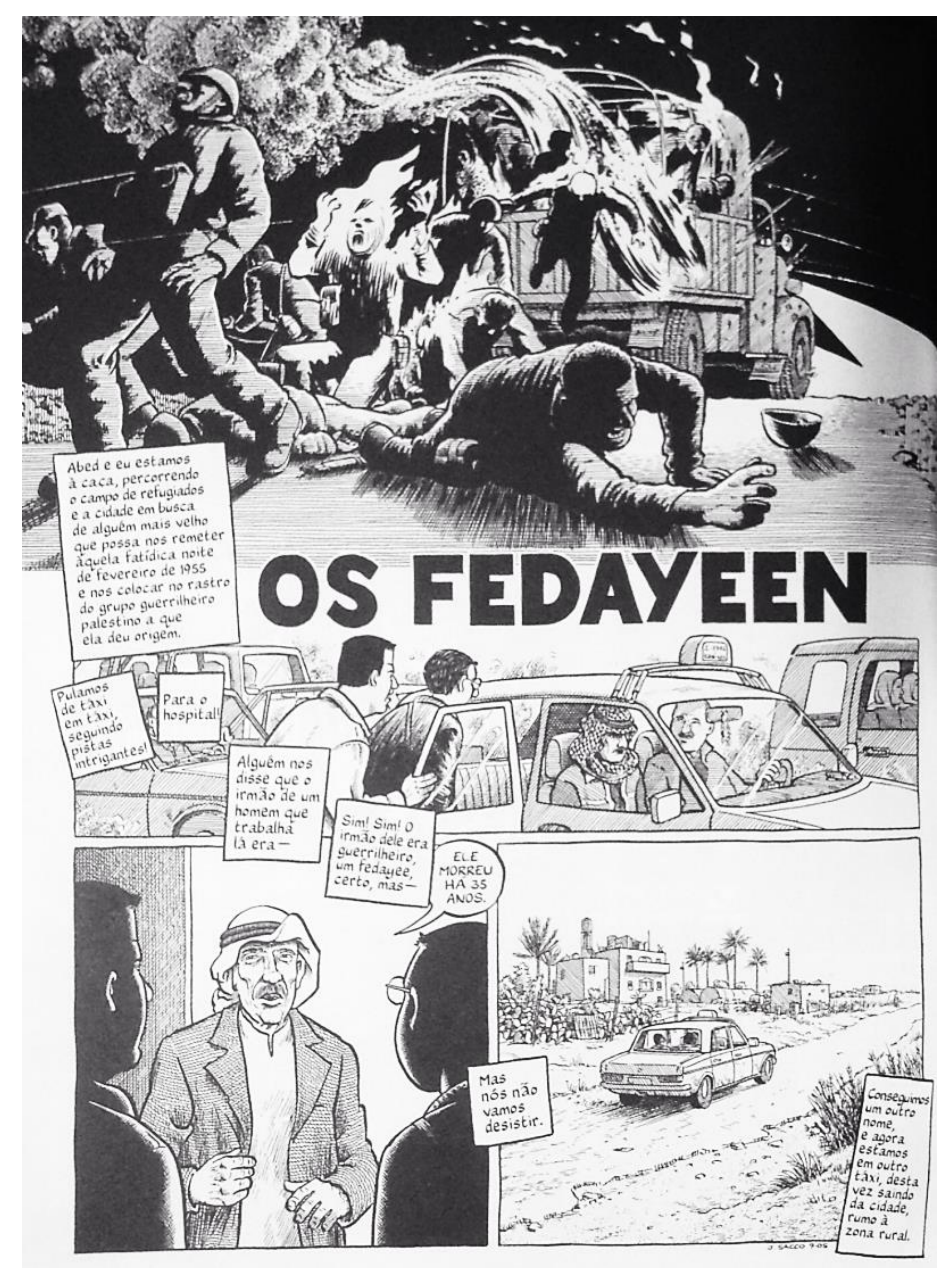

Figura 6. Roupas tradicionais - cafia, guthra e igal

Fonte: Notas sobre Gaza. (SACCO, 2010, p.40)

Na página seguinte (p.41), a legenda do primeiro quadro relata o momento pelo qual ambos tanto aguardavam: a entrevista com o fedayee. Ao descrever o anseio em conhecê-lo, Sacco usa a expressão "inshallah". Com o uso da transliteração, seguida do procedimento tradutório explicitação "se Deus quiser". A expressão poderia ter sido deixada em árabe mesmo no texto em português, por conta de uma novela televisiva que ficou amplamente conhecida. Visto que a adição de palavras estrangeiras no texto seguidas de explicações é uma opção do autor, o tradutor identifica esse aspecto como uma marcação e reproduz o mecanismo da mesma forma em português.

Na segunda vinheta, o leitor tem o primeiro contato com a figura do fedayee: um senhor de idade, alto, barbudo, vestindo uma túnica e usando um turbante na cabeça. Ele 
se dirige ao jornalista e seu intérprete dizendo: "Salaam aleikum". Os dois respondem, na terceira vinheta, “Aleikum es-salaam" (Figura 7). Não há a tradução nestes dois quadros do significado. No entanto, compreende-se que se trata de um cumprimento ${ }^{52}$ comum entre as pessoas daquela região. No terceiro quadro, Sacco continua a sua narrativa sobre a entrevista com um guerrilheiro e, de certa forma, explica os cumprimentos - "(...) a última saudação do ritual de cortesia é proferida e respondida" (SACCO, 2010, p.41). Para o leitorado brasileiro essa explicação poderia ser omitida, porém há uma legenda destinada para ela. Excluir essa informação implicaria na alteração da imagem, uma interferência que não costuma ser feita.

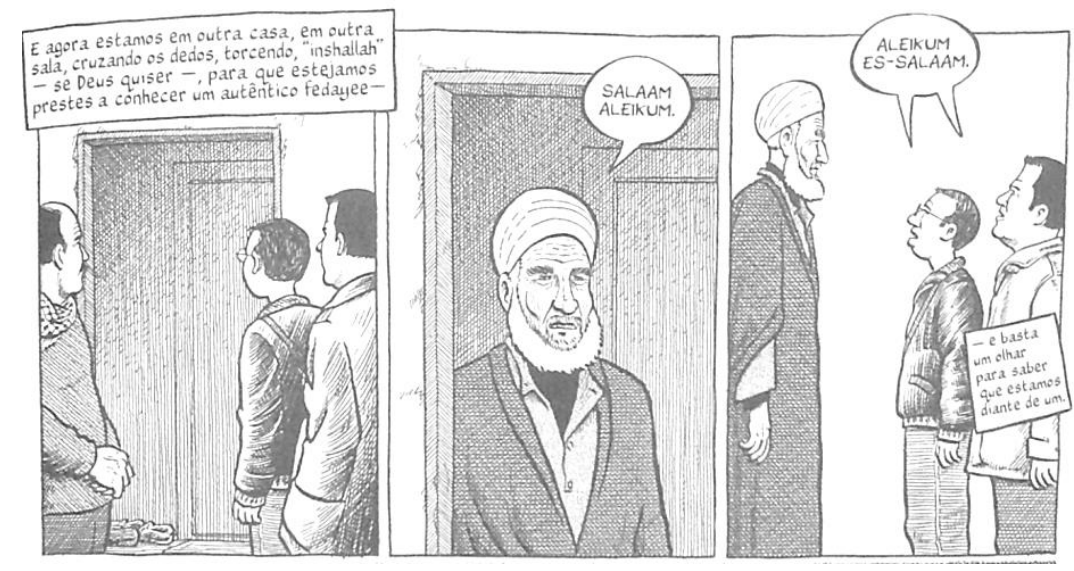

Figura 7. Inshallah, Salaam aleikum e Aleikum es-salaam

Fonte: Notas sobre Gaza (SACCO, 2010, p.41)

Além disso, não há um indicador de que a resposta de Sacco foi interpretada por Abed. O balão de fala com dois apêndices indica que ambos falaram ao mesmo tempo. A resposta em árabe sinaliza que ele aprendeu os cumprimentos básicos por causa de seu trabalho. Possivelmente, tinha que repeti-los de casa em casa enquanto buscava testemunhas para sua reportagem.

Apesar de Sacco estar sempre acompanhado de Abed, ele opta por deixar palavras e frases em árabe. Alexandre Boide, o tradutor de Notas sobre Gaza no Brasil, disse em entrevista que procurou recriar as características do autor no texto de chegada, como as falas truncadas e incomuns nos diálogos (ver Anexo 2), como por exemplo

\footnotetext{
${ }^{52}$ Salaam aleikum "é uma expressão de cumprimento utilizado pelos muçulmanos" Fonte: https://pt.wikipedia.org/wiki/Salaam_Aleikum Acesso online em 22 de fevereiro de 2016.
} 
"Seu eu tivesse entrado, teria gritado e feito um grande [escândalo]" (SACCO, 2010, p.354). O jornalista completa os diálogos de acordo com o contexto e explica, quando necessário, a narrativa e diálogo das testemunhas, a fim de reproduzir as falas transcritas pelo intérprete e ao mesmo tempo deixar as reproduções compreensíveis para o leitor.

No posfácio do autor, Sacco escreve os diálogos da forma como o intérprete lhe passou. A escolha de deixar fragmentos em árabe chama a atenção do leitor de que se trata de um outro sistema linguístico-cultural. Sacco prende sua atenção com a imagem e com a riqueza de informações históricas, culturais, religiosas e, principalmente, linguísticas.

A narrativa sequencial continua e no quinto quadro há outro elemento de alteridade que se refere aos costumes muçulmanos: o Ramadã. A terceira legenda deste quadro fala sobre a restrição de horário por causa do jejum (até pôr-do-sol) e no último quadro, Abed, o intérprete, diz que o ex-guerrilheiro pediu para eles voltarem "à noite, depois do jejum" (SACCO, 2010, p.41), porque o entrevistado precisaria fumar para falar de um assunto tão doloroso (Figura 8). Esta é uma cena que mostra claramente o intérprete atuando.

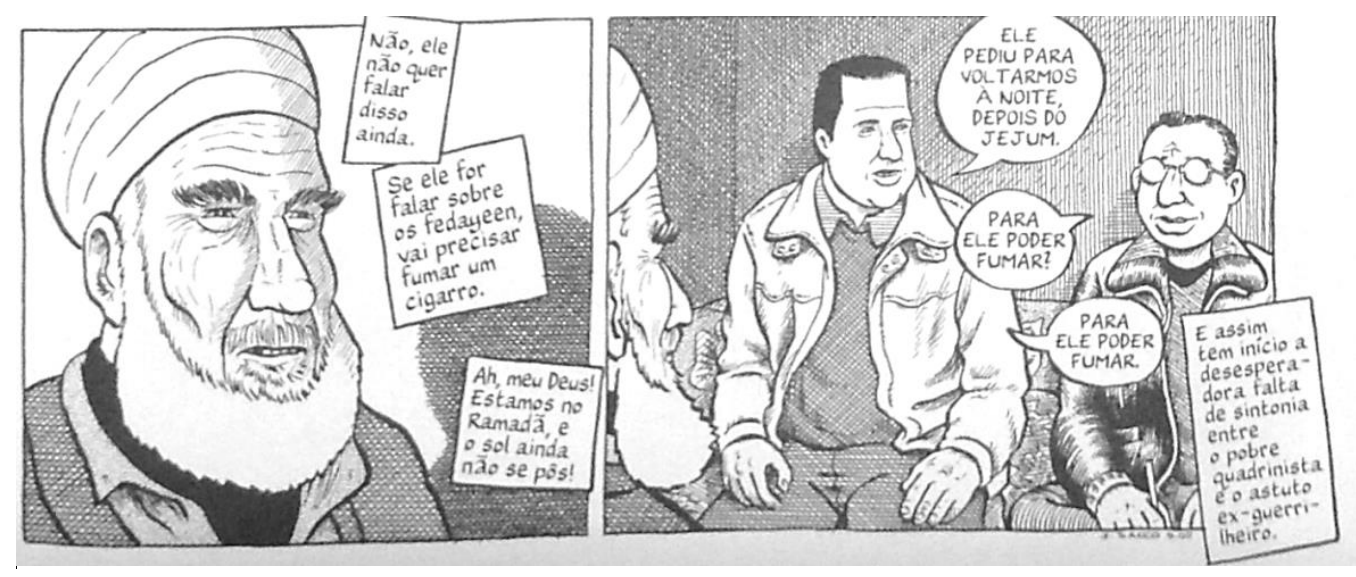

Figura 8. O intérprete

Fonte: Notas sobre Gaza (SACCO, 2010, p.41)

A mediação feita por Abed vai além de um processo linguístico, uma vez que ele sabe sobre a cultura dos dois lados envolvidos na entrevista e Sacco faz questão de 
mostrar a relevância e o papel do intérprete para conseguir testemunhos e outros fatos importantes para a sua narrativa.

\subsubsection{A sensibilidade em diferentes públicos}

Um texto pode ser sensível devido à temática, ao registro e tom do texto, além de estar apresentar modos de sensibilidade. A obra de Sacco, Notas sobre Gaza, apresenta diferentes traços que tornam o texto sensível. A temática de conflitos e guerra dialoga com diversas posições políticas. Apresenta o contraste entre costumes e práticas do Oriente Médio e os do Ocidente. As tradições culturais e religiosas são marcadas no livro. Não são alteradas ou manipuladas, pois têm a função de mostrar a alteridade que muitas vezes é esquecida em outras mídias.

Para entender os públicos da publicação em inglês e português, é necessário compreender um pouco da política externa com ambos os países. Brasil e os EUA assumem posturas diferentes ao apoiar ou se opor aos Estados envolvidos em acordos de cessar-fogo e de paz.

A política externa dos EUA tende a apoiar Israel, o contrário ocorrendo no Brasil. Segundo o sítio do $\mathrm{MRE}^{53}$, as relações Brasil-Palestina remontam a 1975 quando a Organização para a Libertação da Palestina (OLP) enviou seu primeiro representante para solo brasileiro. Em 2010, o Brasil reconheceu o Estado da Palestina e "apoia o direito de autodeterminação do povo palestino e uma solução negociada para o conflito com Israel que resulte em dois Estados, coexistindo pacificamente, lado a lado" ${ }^{\text {"54 }}$. O uso desproporcional de força por parte do exército israelense deixou vários civis palestinos

\footnotetext{
${ }^{53}$ Sigla para Ministério das Relações Exteriores, ministério brasileiro para assuntos de relações exteriores.

${ }^{54}$ Informação retirada do sítio eletrônico do Ministério das Relações Exteriores (MRE). Fonte:

http://www.itamaraty.gov.br/index.php?option=com_content $\&$ view=article \&id=5629\&Itemid=478\&cod pais=PLN\&tipo=ficha_pais\&lang=pt-BR Acesso online em 23 de fevereiro de 2016.
} 
mortos, entre eles mulheres e crianças. O governo brasileiro emitiu uma nota na qual repudiava a escalada de violência por parte de Israel na Faixa de Gaza em $2014^{55}$.

Os EUA, durante muito tempo, procuraram criar um diálogo entre Israel e Palestina para chegarem a um acordo de cessar-fogo e, enfim, a acordo de paz ao longo dos anos. Entretanto, em 2012, o poder do governo palestino foi dividido entre a Autoridade Palestina (AP) e Hamas. A AP ficou com o domínio da Cisjordânia e o Hamas com Gaza. Devido à disputa de poder, os EUA não podem lidar diretamente com os palestinos porque classificam o Hamas como grupo terrorista e não negociam com terroristas $^{56}$.

O grau de apoio americano a Israel varia bastante com o partido político e as promessas de campanhas de cada candidato à presidência. Na corrida presidencial atual alguns candidatos preliminares se destacam em uma das margens. Segundo Chacra $\left(2016^{57}\right)$, "Marco Rubio e Ted Cruz, do Partido Republicano, são os candidatos mais abertamente defensores da direita de Israel na história recente dos Estados Unidos". Rubio e Cruz apresentam posicionamentos extremos não só para a posição de presidente americano, como também para a de um premiê israelense. Para Chacra (idem), o radicalismo deles tange quatro pontos: 1) a mudança da embaixada dos EUA - de Tel Aviv para Jerusalém; 2) a capital eterna de Israel é Jerusalém; 3) referem-se à Cisjordânia como Judeia e Samaria e a consideram como parte de Israel; e 4) suspenderão a ajuda financeira para a AP.

Apesar de serem de partidos diferentes, os candidatos Donald Trump, do partido republicano, e Hillary Clinton, do partido democrata, defendem a solução de dois Estados, e assumem o compromisso de tentar negociar a paz. Bernie Sanders, do mesmo partido de Hillary, apoia a solução de dois Estados. Apesar de ser judeu e ter vivido

\footnotetext{
${ }^{55}$ Nota emitida pelo governo brasileiro. Fonte: http://www.brasil.gov.br/governo/2014/07/brasil-condenaescalada-de-violencia-entre-israel-e-palestina\# Acesso online em 23 de fevereiro de 2016.
56 "can't deal directly with the Palestinians because we've labeled Hamas a terrorist group. And we don't negotiate with terrorists". Fonte: http://www.usatoday.com/story/news/world/2014/08/01/ozy-israel- palestine/13455651/ Acesso online em 20 de fevereiro de 2016.

${ }^{57}$ Como os candidatos nos EUA vêem Israel-Palestina? Fonte:

http://internacional.estadao.com.br/blogs/gustavo-chacra/como-os-candidatos-nos-eua-veem-israelpalestina/ Acesso online em 23 de fevereiro de 2016. 
durante um tempo em um kibbutz na juventude, o governo de Benjamin Netanyahu não deixa de ser alvo de suas críticas. Chacra (idem) diz que "Sanders representa o pensamento tradicional de parte da comunidade judaica americana”. Sanders ama Israel, mas não concorda com o embate que perdura até hoje entre israelenses e palestinos. Assim como ele, muitos judeus pensam dessa forma.

Os EUA assumem um papel mais ativo e presente nas negociações dos acordos de paz entre Israel e Palestina, porém o apoio a Israel ou Palestina depende bastante do governo desses países e do clima político da região. Pode-se inferir que o público leitor americano de Sacco é diferente do público leitor da tradução, pois os vínculos diplomáticos diferem, assim como a função que os países desempenham para alcançar a paz na região. Apesar dessas diferenças, é possível dizer que ambos os públicos se interessam por temáticas de conflito e pelo trabalho desenvolvido por Sacco para documentar e trazer à tona uma realidade muitas vezes encarada como notícia passada. Boide acredita:

[...] que haja uma coincidência perfil, o de leitores que, além dos quadrinhos, leem também textos de não-ficção e reportagens. Por outro lado, não acredito que, no Brasil, o trabalho de Joe Sacco tenha um público que vá além dos leitores já habituados a ler quadrinhos, mas não tenho nenhum elemento para comprovar isso, trata-se apenas de uma impressão pessoal (Entrevista com Alexandre Boide, janeiro de 2016, Anexo 1).

\subsection{ANÁLISE DAS ESTRATÉGIAS DE TRADUÇÃO}

Notas sobre Gaza apresenta diversos aspectos que tornam a obra um texto sensível. A temática, as ilustrações e as informações presentes nos diálogos, testemunhos, dados e fatos mostram um olhar humano subjetivo e objetivo ao mesmo tempo. Com o intuito de entender quais aspectos contribuem para a (in)sensibilidade da tradução do texto, alguns trechos do livro foram selecionados com o propósito de identificar as estratégias tradutórias que de alguma forma afetam ou influenciam os 
modos de sensibilidade do texto original. Para melhor exemplificar, algumas passagens de diferentes partes da obra foram selecionadas, dentre elas, quadros dos capítulos Lama, barracas, tijolos, A única opção, O procurado e Celebração.

\subsubsection{Gota d'água}

Em Lama, barracas, tijolos, Sacco narra o início da história conflituosa entre Israel e Palestina: a formação do Estado de Israel, em 1948. A população da região de Gaza triplicou quando "centenas de milhares de palestinos (...) fugiram ou foram expulsos pelas forças israelenses" (SACCO, 2010, p.21). Cerca de 20 mil palestinos se refugiaram naquela pequena porção de terra. Omm Awad El-Najeeli, uma das senhoras entrevistadas pelo jornalista, conta que a situação era bem difícil por causa da escassez de comida, combustível e água. Em um determinado momento, quando Sacco pergunta sobre água, a senhora responde que era preciso caminhar bastante para conseguir uma jarra de água. Nesse trecho, a tradução se torna um pouco mais sensível que o original (Figuras 9 e 10).

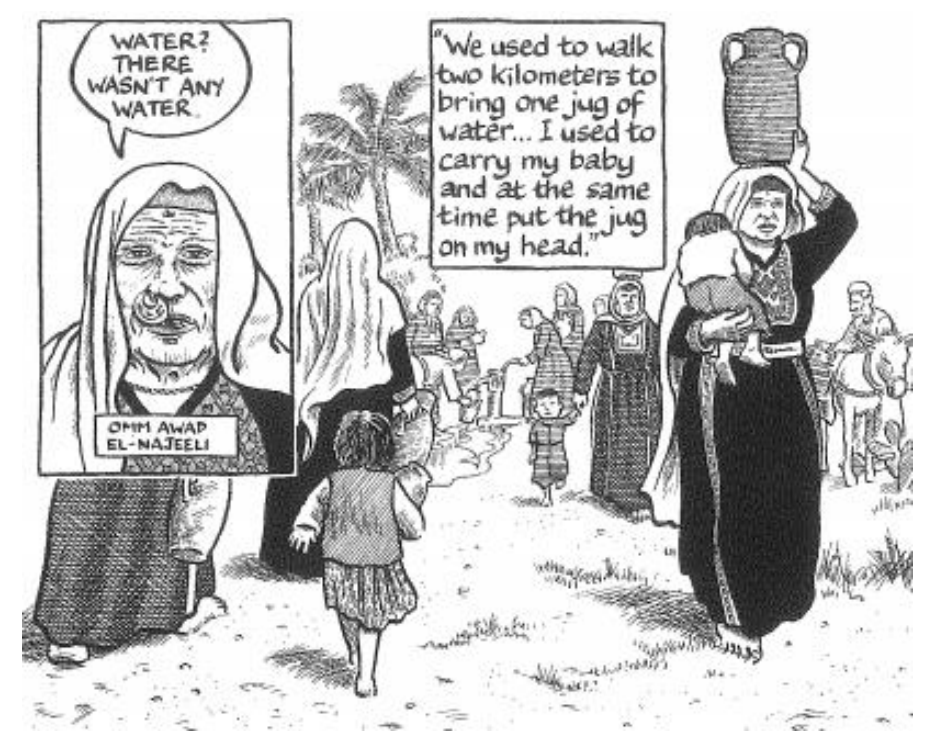

Figura 9. Water

Fonte: Footnotes in Gaza (SACCO, 2009, p.23) 


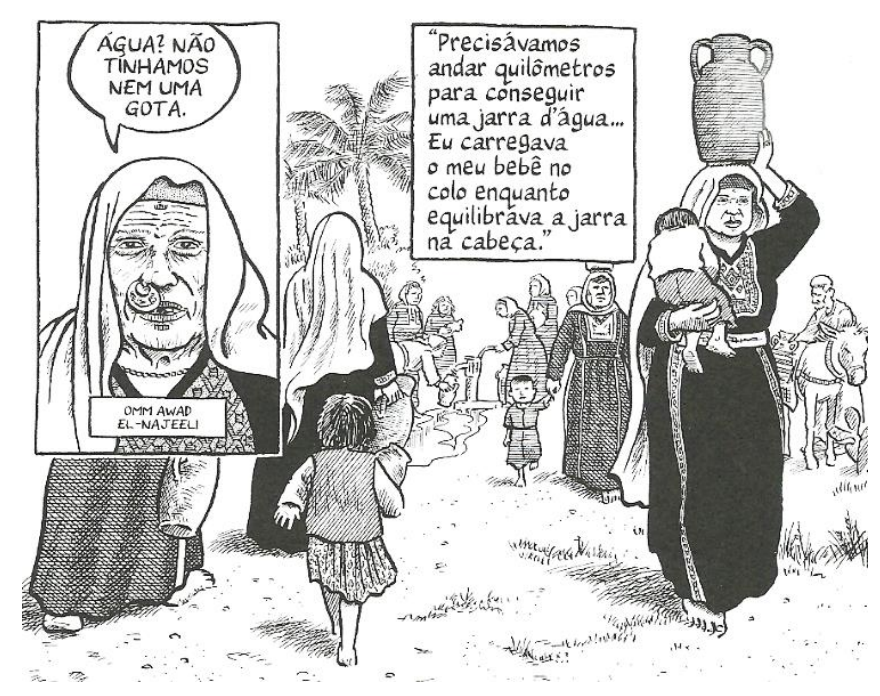

Figura 10. Água

Fonte: Notas sobre Gaza (SACCO, 2010, p.23)

Tabela 1.

\begin{tabular}{|c|c|}
\hline Texto em inglês & Texto em português \\
\hline $\begin{array}{c}\text { "Water? There wasn't any water." (grifo } \\
\text { meu) }\end{array}$ & $\begin{array}{l}\text { "Água? Não tínhamos nem uma gota." } \\
\text { (grifo meu) }\end{array}$ \\
\hline
\end{tabular}

A tradução literal desta passagem seria “Água? Não havia água”. No entanto, para manter o uso de duas negações como no inglês - "wasn't" e "any" - o tradutor escolheu reformular a frase. Com o uso de "não" e "nem", o recurso é reproduzido em língua portuguesa. A ênfase, porém, para a escassez de água, passa a ser "gota". A opção de traduzir "water" por "gota" chama a atenção para a ínfima quantidade de líquido. A imagem acústica é diferente do simples fato de se mencionar "água". Assim, a escolha de reproduzir o mecanismo de negação do texto de partida e com a mudança de signo, de "água" para "gota”, o tradutor enfatiza a falta de água na região com uma expressão comum em português. 


\subsubsection{Para inglês ver}

Em A única opção, Sacco conversa com um velho amigo de Abed. O jornalista ressalta que este amigo fala muito bem inglês, quase de forma impecável, e é muito culto. O seu trabalho para uma agência humanitária do governo dos EUA envolve "a democratização e o fortalecimento da sociedade civil palestina" (SACCO, 2010, p.33). Em seguida, o personagem diz o que acha de seu trabalho.

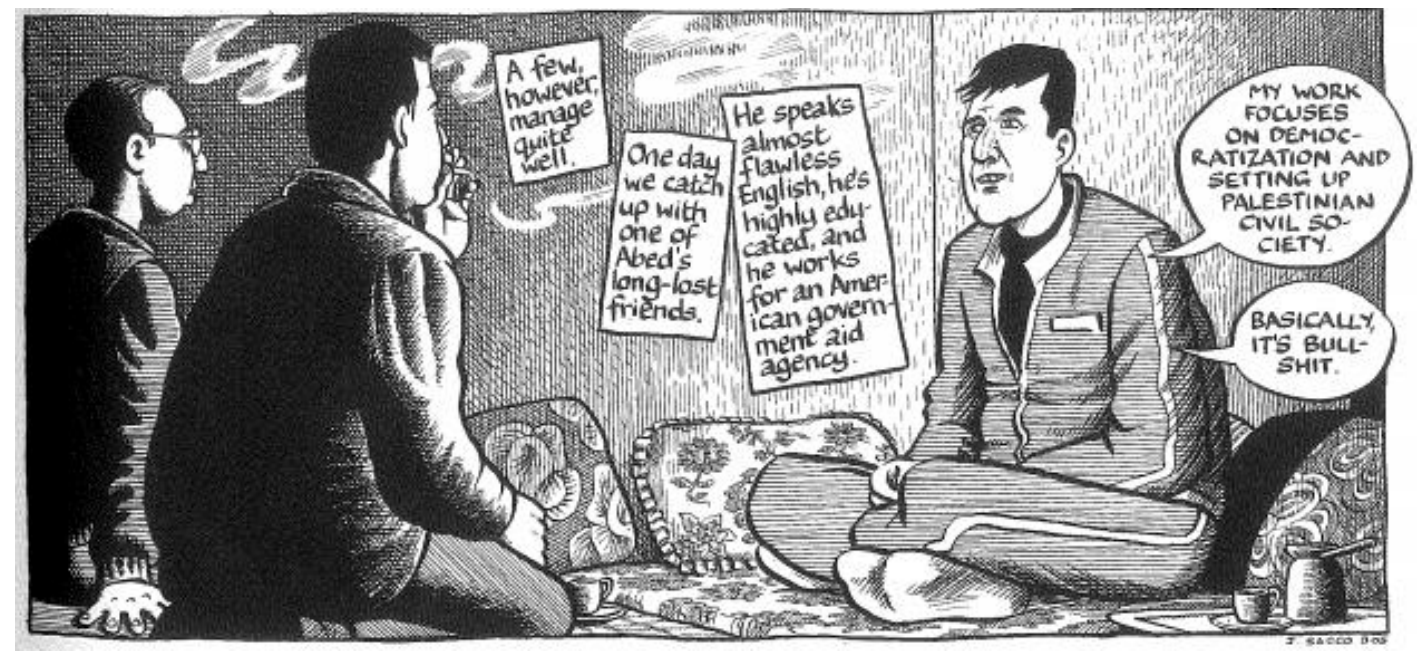

Figura 11. It's bullshit

Fonte: Footnotes in Gaza (SACCO, 2009, p.33)

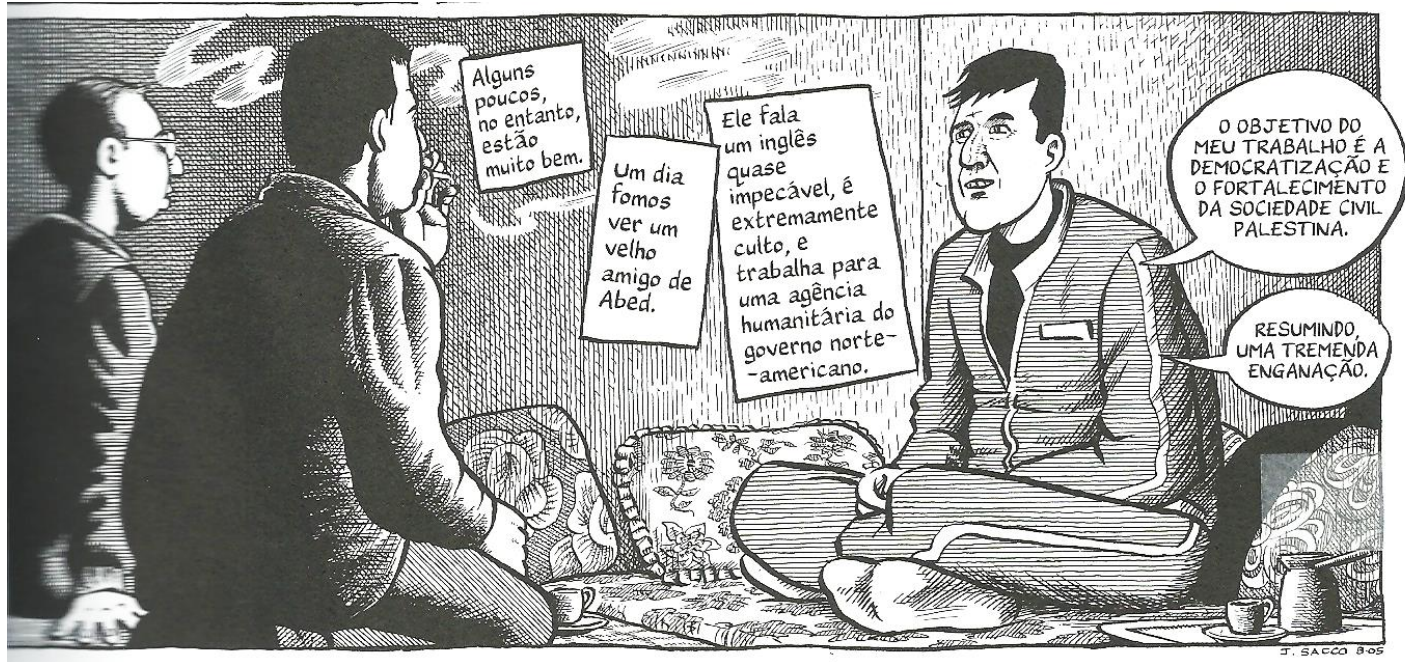

Figura 12. Uma tremenda enganação

Fonte: Notas sobre Gaza (SACCO, 2010, p.33) 
Tabela 2.

\begin{tabular}{|c|l|}
\hline \multicolumn{1}{|c|}{ Texto em inglês } & \multicolumn{1}{|c|}{ Texto em português } \\
\hline “Basically, it's bullshit." (grifo meu) & $\begin{array}{l}\text { "Resumindo, uma tremenda enganação." } \\
\text { (grifo meu) }\end{array}$ \\
\hline
\end{tabular}

Neste determinado balão, o tradutor teve a liberdade de optar por traduzir um léxico pelo outro porque não havia uma relação imagética. No texto em inglês, a indignação dele é explicitada por "bullshit" ${ }^{, 58}$. Apesar de carregarem sentidos parecidos, as palavras "bullshit" e "enganação 59 " têm tons diferentes. Uma traz uma conotação ofensiva e vulgar ${ }^{60}$, mas a outra não. A tradução aponta o pensamento do tradutor; possivelmente, uma forma de censura e ideologia implícita. Todavia, é necessário ressaltar que a tradução final do texto não depende unicamente do tradutor. No caso de Notas sobre Gaza, Boide teve a "oportunidade de fechar o texto final, incorporando as sugestões da pessoa que fez a preparação do texto, que foi tradutora de várias obras do autor, o que naturalmente foi de grande valia" (Anexo 1).

Levando em consideração o fato de que o personagem tinha um bom domínio do idioma, era extremamente culto e trabalhava para uma organização estrangeira, ele saberia que o tom de seu discurso seria informal e franco. A palavra "enganação" deixa o tom mais ameno, apesar de replicar a ideia de algo que não é verdadeiro. O acréscimo do adjetivo "tremenda" influencia na intensidade, no tamanho da enganação, o tom é bastante neutro.

\footnotetext{
${ }^{58}$ A definição de bullshit de acordo com o dicionário Cambridge é de algo sem sentido ou algo que não é verdade. Fonte: http://dictionary.cambridge.org/dictionary/english/bullshit Acesso online em 21 de fevereiro de 2016.

${ }^{59}$ De acordo com a definição do dicionário Priberam, "enganação" significa "ato ou efeito de enganar". Fonte: http://www.priberam.pt/dlpo/engana\%C3\%A7\%C3\%A3o

${ }^{60}$ No dicionário Merriam-Webster, bullshit aparece como uma palavra normalmente vulgar. http://www.merriam-webster.com/dictionary/bullshit Acesso online em 21 de fevereiro de 2016.
} 
A fim de reproduzir o registro informal, uma opção possível seria "Basicamente, é uma lorota ${ }^{61}$ ". O aspecto de informalidade seria recriado por ser uma palavra de uso popular, apesar de não se recriar a vulgaridade. Outra alternativa seria "Resumindo, é só pra inglês ver." A expressão "para inglês ver" tem o sentido de algo "para efeito de

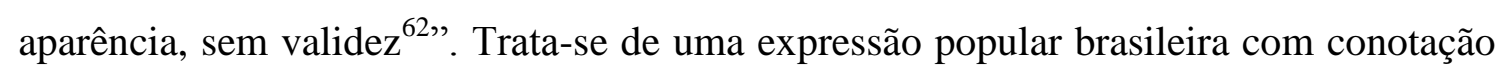
coloquial. Além disso, outra relação seria ativada, a noção dos locais com os estrangeiros e a fachada que muitas organizações ostentam.

\subsubsection{De pouquinho em pouquinho}

A censura é uma das formas de controle exercida quando se trata de textos sensíveis. Um texto pode ser censurado por diversos motivos: políticos, sociais, religiosos, tabu etc. A presença de palavrões, linguajar vulgar, palavras preconceituosas ou degradantes podem levar a uma edição do texto, a fim de torná-lo aceitável, adequado, polido e neutro. Ao alvejar o texto, diminui-se a possibilidade de escandalizar ou chocar o público leitor.

$\mathrm{Na}$ tradução de textos sensíveis, esta é uma prática constante que insiste em mediar o conteúdo disponibilizado na obra. Todavia, a marcação no discurso escrito no texto fonte deve ser recriada no texto alvo. A motivação por trás da linguagem chula, por exemplo, indica o direcionamento e o tom da narrativa. Na reportagem de Notas sobre Gaza, Sacco transita entre o registro coloquial e padrão. Sempre que possível, ele busca apontar as situações descontraídas e as mais sérias.

Em sua pesquisa de campo na cidade de Rafah, Sacco presencia o resultado da passagem dos tratores em meio às áreas residenciais. No capítulo Pior antes, pior agora

\footnotetext{
${ }^{61}$ A definição de "lorota" de acordo com o dicionário Priberam é, "1. [Brasil, Popular] Mentira, conversa fiada; gabarolice; 2. História mal contada". Fonte: http://www.priberam.pt/dlpo/lorota Acesso online em 21 de fevereiro de 2016.

${ }^{62}$ Sobre palavras - Como surgiu a expressão para inglês ver. Fonte: http://veja.abril.com.br/blog/sobrepalavras/consultorio/como-nasceu-a-expressao-para-ingles-ver/ Acesso online em 21 de fevereiro de 2016.
} 
(p.248), Abed, Sacco e Ashraf andam dentre os destroços das casas. Ashraf mostra onde a casa de seu pai tinha sido construída e onde muitas outras também haviam sido construídas pela empreiteira de seu pai. No primeiro quadro, o trio passa pelos esqueletos das casas nas ruas abandonadas. Ashraf começa o diálogo demonstrando sua indignação com a ofensiva israelense (Figuras 13 e 14). Demonstra sua raiva e frustração usando um palavrão. Os palavrões têm a sua relevância e funcionam como uma ferramenta para traduzir "com maior fidelidade nossos mais fortes e genuínos sentimentos"63.

Apesar do julgamento que muitos fazem do uso de palavras chulas, a verbalização de um palavrão implica na externalização de um sentimento. Para Jorge (2014, p.77), "O palavrão é uma distração da dor em si, do problema que está incrustado na alma. Palavrão não é bobagem. O palavrão é uma espada perversa."

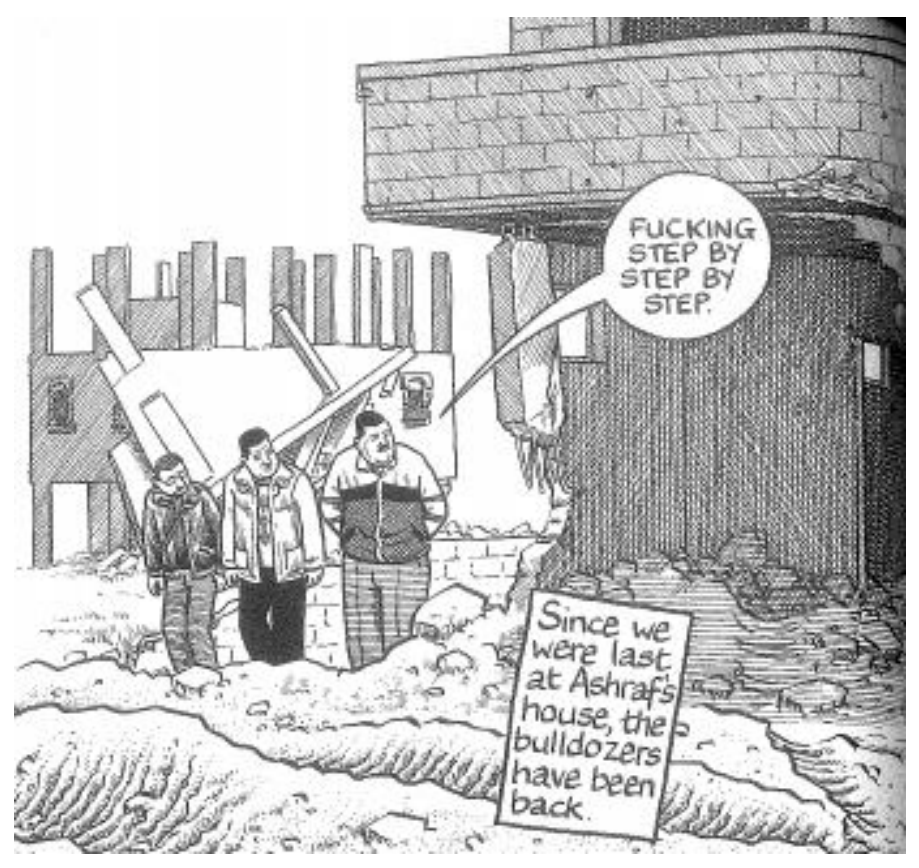

Figura 13. Step by step by Step

Fonte: Footnotes in Gaza (SACCO, 2009, p.248)

${ }^{63} \mathrm{O}$ direito ao foda-se, de Pedro Ivo Resende, sem data. Fonte:

http://stoa.usp.br/briannaloch/weblog/1754.html Acesso online em 26 de fevereiro de 2016. 


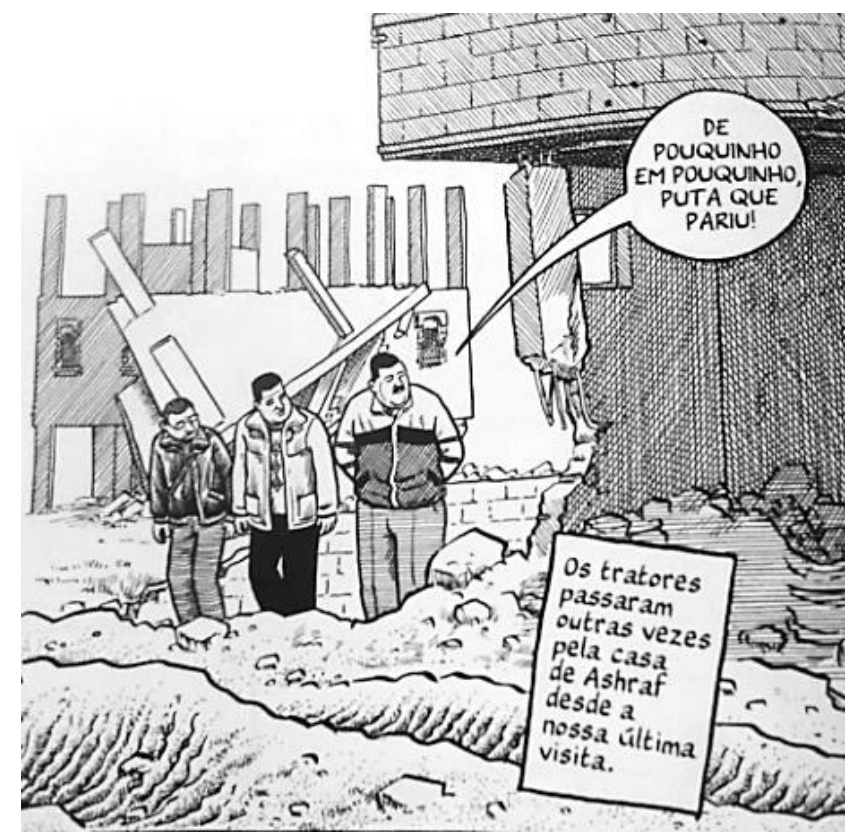

Figura 14. De pouquinho em pouquinho

Fonte: Notas sobre Gaza (SACCO, 2010, p.248)

Tabela 3.

\begin{tabular}{|c|c|}
\hline Texto em inglês & Texto em português \\
\hline $\begin{array}{l}\text { "Fucking step by step by step!" (grifo } \\
\text { meu) }\end{array}$ & $\begin{array}{l}\text { "De pouquinho em pouquinho, puta que } \\
\text { pariu!" (grifo meu) }\end{array}$ \\
\hline
\end{tabular}

No trecho analisado anteriormente, o tradutor neutralizou o vocábulo "bullshit",

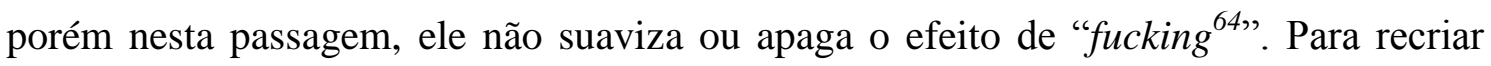
com força e emoção, "fucking" perde a função de adjetivo que tinha no texto fonte, e ganha a função de interjeição como "puta que pariu". O destaque para o palavrão é maior em português devido ao deslocamento dado.

\footnotetext{
${ }^{64}$ De acordo com o dicionário Cambridge, a palavra fucking é ofensiva, desempenha a função de adjetivo ou advérbio e é usada para enfatizar uma afirmação, normalmente com tom de raiva.

Fonte: http://dictionary.cambridge.org/pt/dicionario/ingles/fucking Acesso online em 24 de fevereiro de 2016.
} 
Apesar de ter alongado mais o texto na tradução, o ritmo de "step by step by step" foi reproduzido em "puta que pariu". Além disso, o tradutor conseguiu atrair a atenção do leitor com a repetição das letras " $s$ " e "p" que acontece em inglês três vezes, uma em cada "step" e quatro em português no período todo: "pouquinho em pouquinho, puta que pariu!"

Outro aspecto importante que merece atenção é o uso do sufixo diminutivo inho. A ideia de progressão, quantidade reduzida e de modo insuficiente é um eufemismo na fala de Ashraf. Segundo Costa (2003), nos substantivos, advérbios e adjetivos, as formas sintéticas dos diminutivos indicam "várias manifestações da emoção e das intenções do falante". Ademais, o diminutivo pode ter a significação de tom afetivo, aumentativo, desempenhar o papel do eufemismo e ironia dependendo do contexto onde se encontra.

Apesar de "step by step by step" 55 " denotar repetição excessiva de passos ou coisas que deve ser realizadas em uma determinada ordem, "de pouquinho em pouquinho" carrega um valor de superlativo. De Oliveira (2010) explica que "O sufixo inho (a) admite usos bastantes variados e só pelo contexto, é que poderá ser analisado seu significado, de acordo com a real intenção do falante." Conforme o contexto que a fala de Ashraf está inserida, é plausível fazer a inferência de que o "pouquinho", na verdade, seria um "tantão". Dentro da imensidão de detritos na qual os personagens se encontram, é difícil depreender a noção de algo gradativo e diminuto quando se trata das demolições de inúmeros lares em Rafah.

\subsubsection{Deus ou Alá?}

Cada história em Notas sobre Gaza pode ser compreendida como um degrau para a construção global do passado, presente e futuro da Palestina. A criação da Faixa

\footnotetext{
${ }^{65} \mathrm{O}$ verbete "step" tem várias entradas; porém, como "step by step" a definição é "lidar com uma coisa e depois outra em uma ordem fixa".

Fonte: http://dictionary.cambridge.org/pt/dicionario/ingles/step?q=step+by+step Acesso online em 24 de fevereiro de 2016.
} 
de Gaza, o desenvolvimento da OLP e os conflitos entre Israel e Egito resultaram em uma nação em busca de identidade, espaço geográfico e legitimação de seu próprio Estado. Apesar do sofrimento constante, a incerteza do amanhã, a falta de proteção e segurança, a suscetibilidade a qualquer tipo de ataque, a dependência da religião é o fio de esperança que não se rompe.

O islamismo é uma das maiores religiões monoteístas. A prática da fé islâmica prega a compaixão, o amor ao próximo, a assistência aos pobres e necessitados. Porém, por causa de religiosos extremistas, radicais muçulmanos e regras sem flexibilidade, os mulçumanos foram amplamente categorizados no Ocidente como terroristas, homens bombas, machistas e impiedosos, gerando uma onda de preconceito em vários lugares do mundo. Esta visão reducionista mancha o exemplo de vida e fé da grande maioria dos praticantes.

A relevância da religião muçulmana no texto de Sacco é impressionante. O autor marca no texto escrito a palavra "God" e essa marca é reproduzida na tradução também com "Deus". Duas vertentes podem ser compreendidas neste fenômeno: uma maneira de diminuir ou desmistificar os possíveis preconceitos que o leitor tenha ou uma maneira de ocidentalizar e mascarar o deus islâmico.

Não é possível excluir o fator religião na narrativa, pois é ela que dá esperança, justifica os acontecimentos do destino, funciona como pilar fundamental da vida. $\mathrm{O}$ islamismo, segundo Karen Armstrong (2001 apud Abidin, 2012), é como as grandes religiões do mundo: prega compaixão e justiça ${ }^{66}$. Ela ressalta que a tradução de "Allah" não é exclusivamente para um deus mulçumano, pois se trata de "um único Deus", sendo um conceito comum para outras religiões. As duas principais características usadas para se referir a Deus são comuns também ao judaísmo e ao cristianismo: o mais benevolente e misericordioso ${ }^{67}$.

Alguns dos ensinamentos básicos deixados pelo profeta Maomé são: as ações são julgadas de acordo com a intenção por trás delas, uma pessoa não pode ser um

\footnotetext{
${ }^{66}$ ABIDIN, Danial Zainal. Islam the misunderstood religion. Kuala Lumpur:PTS Millenia,2012.

${ }^{67}$ Fonte: http://www.icna.org/islam-does-not-preach-violence/ Acesso online em 3 de março de 2016.
} 
verdadeiro crente se não amar seu irmão como a si mesmo, não se preocupar com as coisas mundanas e não deve se ferir a si mesmo ou aos outros ${ }^{68}$.

Assim, é importante ressaltar as inúmeras ocorrências da palavra "Deus (God)" no texto. No livro inteiro, a palavra é usada 30 vezes, 29 dentre as quais nas falas de personagens palestinos. Somente em um caso ela foi usada por Sacco. Porém, o que é intrigante é o fato de Sacco usar a palavra "Alá (Allah)" somente uma vez. Ele a usa para descrever a festividade Eid al-Adha (ver item 3.2.5), que faz parte da tradição muçulmana.

A decisão de utilizar "Alá” em um único caso denota que Sacco pode mostrar ao leitor de que se trata de um deus diferente do contexto judaico-cristão. Ao mesmo tempo, este apontamento revela a posição de Sacco como um observador externo. Essa é uma escolha interessante, pois põe em relevo o quanto as duas comunidades - judeus e palestinos - têm em comum.

Durante toda a narrativa, Sacco busca abrir um espaço para homens e mulheres de idade avançada para compartilharem suas memórias e experiências em Khan Younis e Rafah. A noção de um ser que está no controle de todas as coisas está presente em diversos momentos. Sacco constrói novas relações e acepções do deus muçulmano a fim de revelar uma faceta da fé que muitas vezes é ocultada dos ocidentais. Mesmo quando conversa com ex-guerrilheiros, militantes e jovens da resistência palestina, a conotação de uma justificativa de guerra santa não aparece em nenhum momento. Por meio do diálogo e da reflexão, Sacco consegue estabelecer uma ponte pela qual o Ocidente e o Oriente Médio se comuniquem respeitando as diferenças culturais, linguísticas, religiosas e políticas.

Enquanto esperam um VBC (Veículo Blindado de Combate), um tipo de trator, passar pelo Bloco J, Abed e Sacco se sentam no outro lado da rua e conversam com alguns adolescentes. O primeiro adolescente reproduz o discurso amplamente veiculado pela mídia; ele diz: "Eu não gosto deles. Não são muçulmanos. E só Deus sabe se eles estão a nosso favor ou contra nós" (SACCO, 2010, p.193). Ao ser questionado pelo

\footnotetext{
${ }^{68}$ Fonte: http://lincolnmosque.com/core-teachings-of-the-prophet-muhammad-peace-be-upon-him/ Acesso online em 3 de março de 2016.
} 
garoto se é muçulmano, Sacco responde francamente que não. O garoto retruca e lhe diz: "você vai para o inferno". Porém, o jornalista o leva à reflexão e lhe pergunta se o rapaz sente raiva dele por não ser muçulmano. O rapaz reflete e diz que não, mas ao mesmo tempo ele não é seu inimigo nem seu amigo. Para selar o entendimento, eles apertam as mãos.

De forma simbólica e significante, Sacco mostra para a mídia ocidental a necessidade de diálogo e a busca de compreender a realidade externa. Na página seguinte, o jornalista continua conversando, agora com um maior número de adolescentes. Ele pergunta qual seria a melhor forma de resistência na opinião deles e duas posições diferentes se destacam - um dos garotos diz que a melhor solução seria se aproximar de Deus e o outro diz que a resposta seria com bombas. Porém, a dúvida, a incerteza é retratada no rosto dos meninos. Eles querem uma solução. Uma resposta exata para parar com as incursões, demolições, explosões e demais ataques.

\subsubsection{Intensificação da sensibilidade}

As relações que Joe Sacco estabelece com os palestinos que conhece durante sua vasta pesquisa sobre os eventos de 1956 são extremamente significativas na promoção do conhecimento da herança, da memória, da cultura e dos laços familiares.

Foram escolhidos cinco trechos do capítulo Celebração. É um capítulo que serve como pausa entre o testemunho e a pesquisa de Sacco para conseguir material para a sua reportagem. Diferentemente de outros capítulos, Celebração tem um título alegre e mostra um pouco dos rituais muçulmanos.

A história se passa no meio de Eid al-Adha, ou "Festa do Sacrifício", que celebra a ocasião quando Alá apareceu para Abraão em sonho e lhe pediu para sacrificar seu filho Ismael como um sinal de devoção ${ }^{69}$. É importante frisar que este relato

\footnotetext{
${ }^{69}$ Informações sobre o Eid El-Adha Fonte: http://www.telegraph.co.uk/news/worldnews/middleeast/10382365/What-is-Eid-al-Adha.html Acesso online em 20 de fevereiro de 2016.
} 
também faz parte do Velho Testamento, sendo, portanto, um elo de ligação entre o Islã, o Judaísmo e o Cristianismo. É uma das festas mais importantes do calendário islâmico. Cada passagem selecionada para análise revela algum modo sensível do texto traduzido. O primeiro trecho evidencia a diferença cultural, o segundo apresenta a intensificação da sensibilidade na tradução com a inserção de duas palavras no texto, o terceiro trecho mostra como a opção de uma palavra pela outra destaca a sensibilidade do tema, o quarto retrata a troca de referência e o quinto trata do destaque por meio de um sublinhado.

\subsubsection{Só seis anos}

Sacco fala sobre sua pesquisa com alguns familiares de Abed, seu intérprete. Abu Hamed, um dos parentes, pergunta o que ele faz em Gaza. Então, o jornalista lhe explica sobre a sua pesquisa em Khan Younis e Rafah sobre os massacres em 1956. Hamed comenta que tinha seis anos na época e se lembra dos aviões sobrevoando a cidade (Figuras 15 e 16). A passagem é a seguinte:

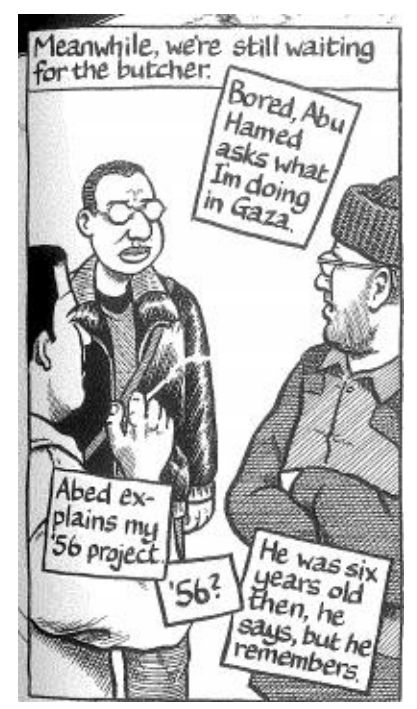

Figura 15. Six years old (SACCO, 2009, p.139) 


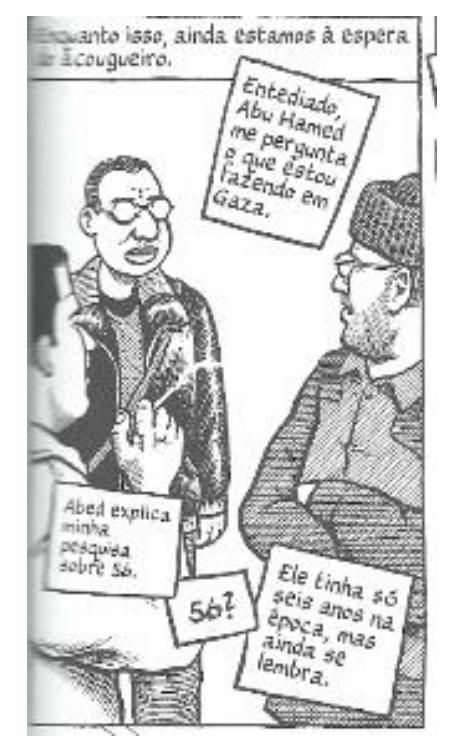

Figura 16. Só seis anos (SACCO, 2010, p.139)

Tabela 3

\begin{tabular}{|l|l|}
\hline \multicolumn{1}{|c|}{ Texto em inglês } & \multicolumn{1}{|c|}{ Texto em português } \\
\hline $\begin{array}{l}\text { "He was six years old then, he says, but he } \\
\text { remembers." }\end{array}$ & $\begin{array}{l}\text { "Ele tinha só seis anos na época, mas ainda } \\
\text { se lembra." (grifo meu) }\end{array}$ \\
\hline
\end{tabular}

No texto original, há a desinência da idade do personagem e a afirmativa que a memória dos acontecimentos ainda é vívida. No trecho traduzido, o procedimento tradutório predominante é a tradução literal ${ }^{70}$. Há um porém nesta estratégia: a inserção de "só". Uma palavra de duas letras implica em um aumento da sensibilidade na tradução, pois ressalta a pouca idade do personagem na época dos ataques.

Além desse acréscimo, a palavra "ainda" também foi inserida e intensifica a distância temporal dos acontecimentos e o fato de a memória ainda estar intacta. Apesar de não estarem no texto de partida, no texto de chegada, juntamente com a imagem, elas permitem que a realidade da memória seja trazida para mais perto do leitor. O contraste entre o momento de festa e a invasão militar israelense na região é ressaltado com a

\footnotetext{
${ }^{70}$ De acordo com a definição de tradução literal de Aubert (1987), “aquela em que se mantém uma fidelidade semântica estrita, adequando porém a morfo-sintaxe às normas gramaticais da LT" (AUBERT, 1987, p.15 apud BARBOSA, 2004, p.65)
} 
tradução comunicativa que "visa a produzir em seus leitores um efeito tão próximo quanto possível do efeito produzido sobre os leitores do original” (BARBOSA, 2004, p.52).

O projeto de tradução com base funcionalista visa a fidelidade com o propósito do texto traduzido. Assim, a lealdade do tradutor não é ao texto original, mas sim às funções que a tradução desempenhará. A fim de recriar os mecanismos para que o texto de chegada seja funcional, o tradutor tem mais liberdade para usar estratégias e procedimentos tradutórios que o ajudem a tecer um novo texto de acordo com os propósitos estabelecidos para o texto traduzido.

\subsubsection{Entrada ou invasão?}

Em sua conversa com Sacco, Hamed conta a sua lembrança de quando era pequeno. No segundo trecho selecionado, ele relata que estava na rua e os ataques aéreos começaram. Segue as figuras (Figura 17 e Figura 18) e a tabela abaixo para comparação:

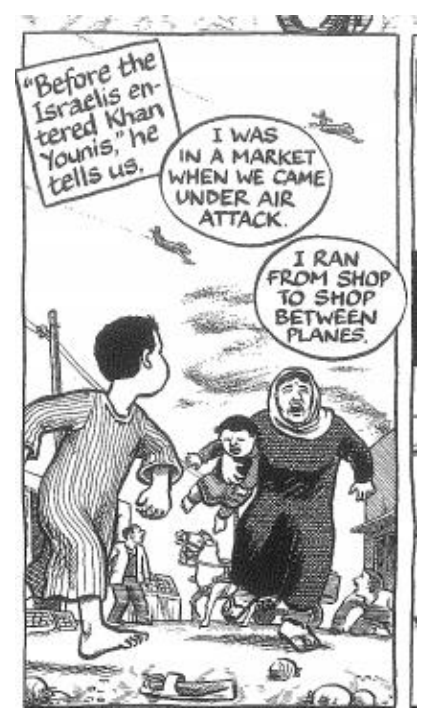

Figura 17. Air attack (SACCO, 2009, p.139) 


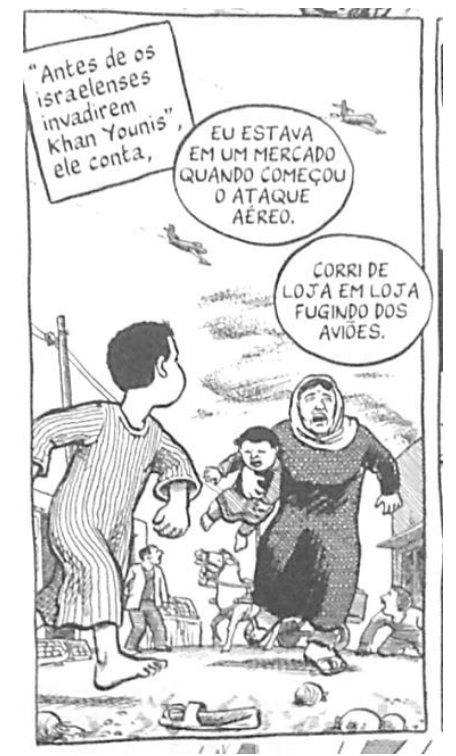

Figura 18. Ataque aéreo (SACCO, 2010, p.139)

Tabela 4.

\begin{tabular}{|l|l|}
\hline \multicolumn{1}{|c|}{ Texto em inglês } & \multicolumn{1}{|c|}{ Texto em português } \\
\hline $\begin{array}{l}\text { "'Before the Israelis entered Khan Younis', } \\
\text { he tells us," (grifo meu) }\end{array}$ & $\begin{array}{l}\text { "Antes de os israelenses invadirem Khan } \\
\text { Younis', ele conta," (grifo meu) }\end{array}$ \\
\hline
\end{tabular}

O procedimento tradutório escolhido foi a tradução literal. Porém, ao invés de traduzir o verbo "enter" 71 " por "entrar", Boide optou por outro verbo, mais forte, “invadir". Devido ao contexto da reportagem e a narrativa sequencial, o fato de os israelenses invadirem a cidade é coerente, mas a marcação mudou.

No texto de partida, a palavra não apresenta uma conotação negativa, mas na tradução o sentido fica muito mais incisivo. A tradução se torna sensível, agora não pela adição de uma palavra, mas pela opção semântica. O tradutor utilizou o contexto, a história, a imagem e seu conhecimento prévio sobre outras obras de Sacco para a

\footnotetext{
${ }^{71}$ A primeira acepção do verbete é de lugar, vir ou ir a um lugar específico.
}

Fonte: http://dictionary.cambridge.org/dictionary/english/enter Acesso online em $1^{\text {a }}$ de março de 2016. 
construção de sentido. $\mathrm{O}$ desenho de aviões israelenses sobrevoando a região, mulheres e crianças correndo na rua, feições de medo e desespero são marcações gráficas na cena. Traduzir "invadir" ao invés de "entrar" remonta à relação extralinguística do texto, reproduzindo e marcando a sensibilidade da obra toda.

\subsubsection{Açougueiro e assistente, pai e filho}

A descrição do sacrifício do boi é bastante impactante, pois ela ocorre na instância verbal e visual do texto. Cada cena mostra o procedimento rotineiro de uma oferta de devoção dos fieis. Um açougueiro foi contratado por se tratar de um animal de grande porte. Ele traz consigo seu filho como auxiliar para fazer o sacrifício. Em determinados momentos, alternam as funções para fazer com que o animal não sofra e os espasmos sejam contidos. Na descrição abaixo, temos o trecho em ambas as línguas.

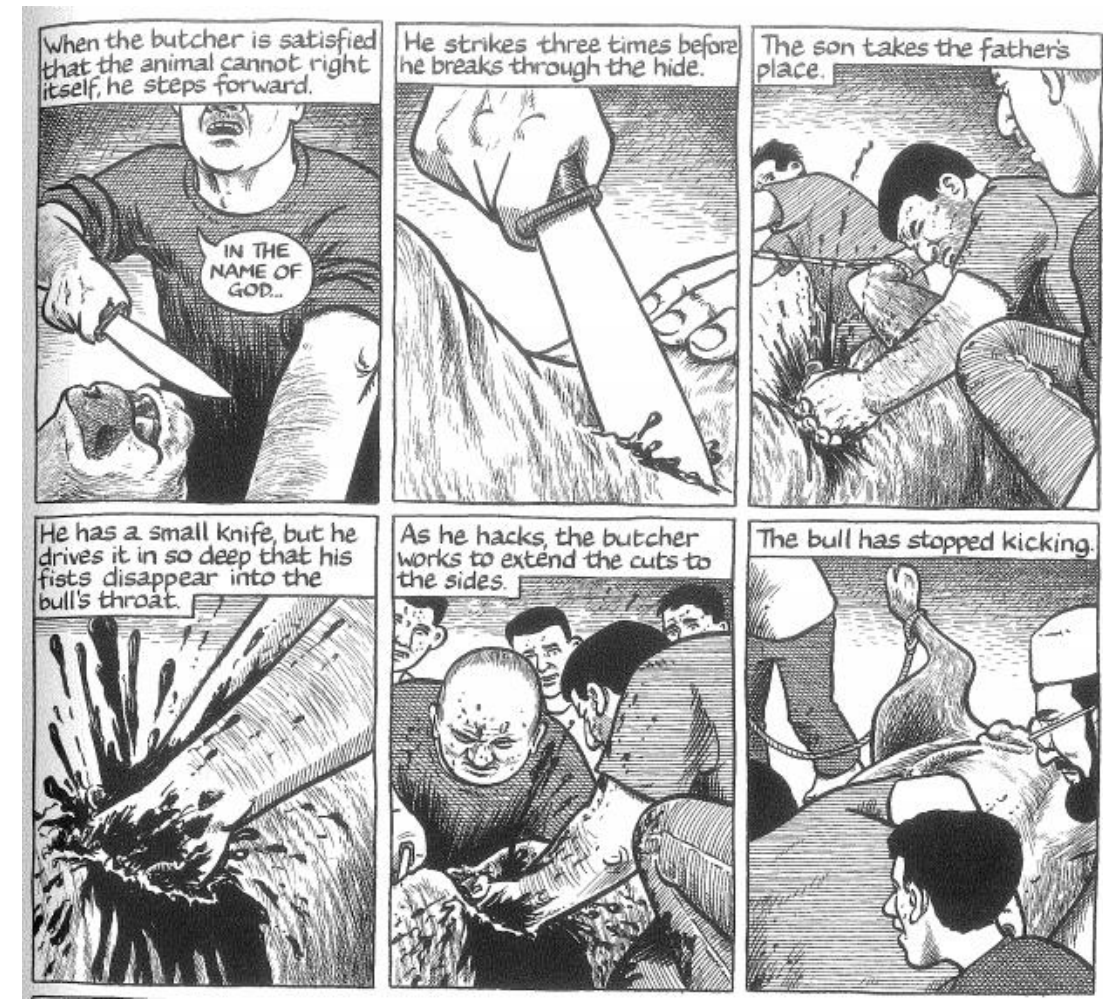

Figura 19. Butcher and father (SACCO, 2009, p.141) 

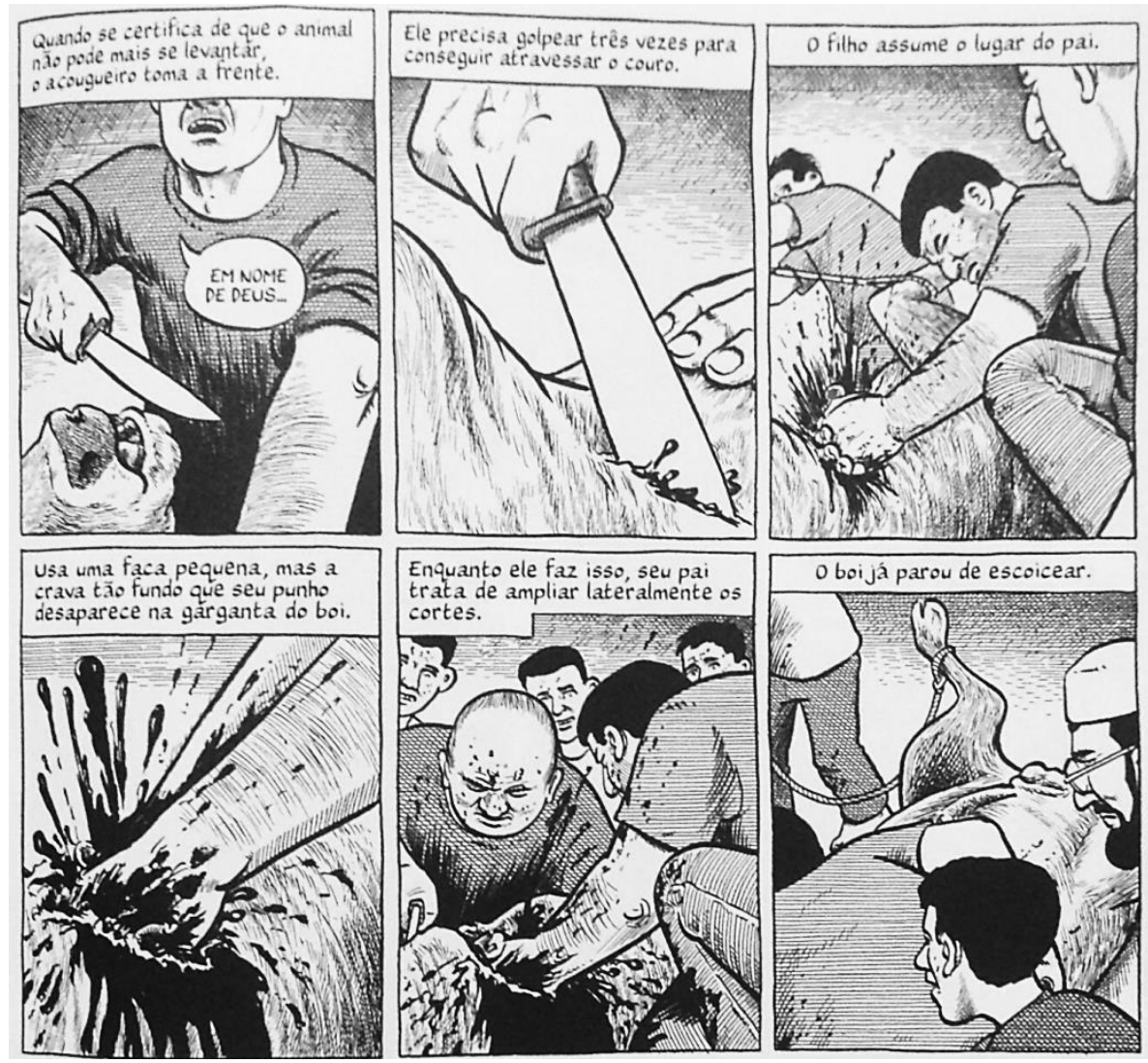

Figura 20. Pai e filho (SACCO, 2010, p.141)

Tabela 5.

\begin{tabular}{|l|l|}
\hline \multicolumn{1}{|c|}{ Texto em inglês } & \multicolumn{1}{|c|}{ Texto em português } \\
\hline $\begin{array}{l}\text { "As he hacks, the butcher works to extend } \\
\text { the cuts to the sides". (grifo meu) }\end{array}$ & $\begin{array}{l}\text { "Enquanto ele faz isso, seu pai trata de } \\
\text { ampliar lateralmente os cortes". (grifo meu) }\end{array}$ \\
\hline
\end{tabular}

O foco da análise deste trecho é a mudança do referencial. Sabe-se que o açougueiro tem seu filho como assistente. A alteração de "butcher" (açougueiro) para "pai" estabelece uma nova relação e alusão ao texto. Possivelmente, a escolha linguística foi uma opção devido à restrição do espaço da legenda. A passagem em inglês tem 50 caracteres sem espaço, a tradução tem 58. Se ao invés de pai fosse “açougueiro", o número aumentaria para 64. 
Porém, a escolha mostra um olhar diferente sobre a situação. Infere-se a alusão ao sacrifício de Ismael por Abraão, mas nesta cena são o pai e o filho que participam do sacrifício, um animal providenciado pelo divino. Além desta conotação, há outra inferência que pode ser feita, a festividade é marcada pela união familiar. A família de Abed, juntamente com outros tios e primos, comprou um boi para sacrificar a Alá e o açougueiro com seu filho marcam também a cumplicidade familiar presente na celebração.

Outro ponto que merece destaque é a forma que o tradutor ameniza "hacks" Sacco obviamente se sente mal com a cena, mas o tradutor não deixa o leitor brasileiro notar isso. A tradução apaga a alteridade (negativa nesse caso) e torna a cena menos brutal, mais naturalizada.

\subsubsection{Na mão dela}

Após o sacrifício do boi, a carne é dividida entre as famílias de cada representante. Cada família recebe um montante e divide a sua porção 1) um terço para a casa; 2) um terço para parentes e amigos próximos; e 3) um terço para os pobres. A mãe de Abed separa um saco e entrega para um de seus filhos e menciona o nome de uma mulher idosa. A fala da mãe foi selecionada para esta análise não por causa da tradução linguística, mas sim por causa do recurso utilizado para enfatizar o seu pedido.

\footnotetext{
${ }^{72}$ A palavra "hack" significa cortar de forma forte e violenta.
} 


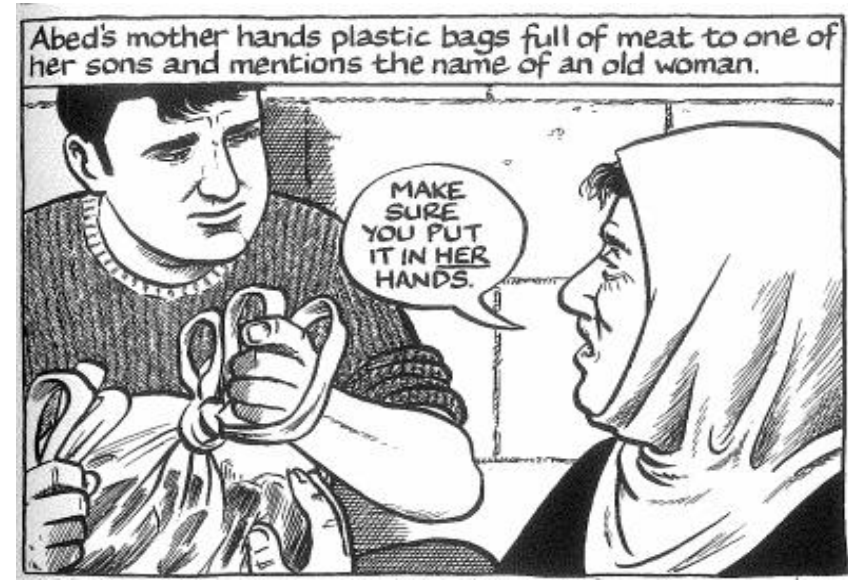

Figura 21. In her hands (SACCO, 2009, p.145)

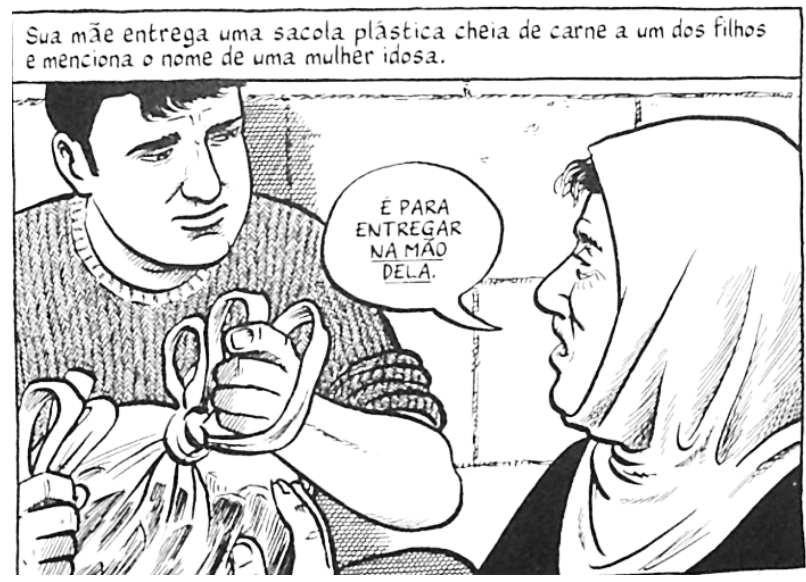

Figura 22. Na mão dela (SACCO, 2010, p.145)

Tabela 6

\begin{tabular}{|c|c|}
\hline Texto em inglês & Texto em português \\
\hline "Make sure you put it in her hands." & "É para entregar na mão dela.". \\
\hline
\end{tabular}

Uma tradução literal do texto original seria: "Certifique-se em colocá-la em suas mãos". No entanto, o tradutor optou por uma maneira mais natural e usual em língua 
portuguesa, ou seja, uma equivalência funcional por meio de uma tradução oblíqua ${ }^{73}$. As mudanças não alteram o sentido do texto, porém a atenção é prolongada através do sublinhado, que passa de uma palavra no texto de partida para três no texto de chegada. A ênfase passa a ser "na mão dela". O recurso extralinguístico acentua as últimas três palavras, provocando o leitor a lê-las com mais destaque e evoca um aumento no volume da imagem acústica. A simulação do tom de voz da mãe é alcançada devido ao sublinhado nas três palavras.

\subsubsection{Estilo do autor em português}

Os diferentes propósitos estabelecidos em uma tradução indicam quem é o público leitor do TT e quais estratégias ou procedimentos tradutórios foram utilizados. O estilo do autor é bastante peculiar, uma vez que está presente na estética da imagem e na cadência de eventos narrados. A fim de identificar como o estilo do autor foi alterado, duas passagens do livro foram selecionadas.

Após uma explosão em Khan Younis, Sacco e Abed visitam uma mulher que ficou machucada no bombardeio. Um dos elementos que chama a atenção é o aspecto cultural. Uma das irmãs perdeu a perna durante o ataque, e ela é solteira. Sacco faz duas perguntas cruciais para si mesmo e para os leitores ocidentais: "Nós temos ideia do que isso significa? Do que isso significa para os planos dela?" É um pouco difícil imaginar o impacto de explosões diárias no futuro de uma jovem palestina solteira. A vida de jovens palestinas solteiras é difícil em uma sociedade patriarcal muçulmana, imagine para uma solteira multilada.

A irmã mais velha, Fatiah, contou o que havia acontecido. Estavam voltando para casa quando o ataque começou. Sentiu algo queimando sua pele e se deu conta de

\footnotetext{
${ }^{73}$ Segundo a definição de Vinay e Dalbernet (1997) de tradução oblíqua descrita por Barbosa (2004, p.25): "utiliza recursos lexicais ou sintáticos diversos daqueles empregados no texto da LO (doravante TLO), quer dizer, que altera a forma, mas sem alterar o conteúdo, ou a mensagem".
} 
que fora atingida. Olhou para os lados; sua sobrinha estava coberta de sangue e a sua irmã perdeu uma das pernas. As pessoas que tentavam ajudá-la acabavam sendo feridas também. Nesta parte, há uma sequência de cenas do bombardeio e Sacco opta por fazer uma sequência narrativa usando a palavra "shell" nas variações de substantivo e verbo nas páginas 295 e 296.

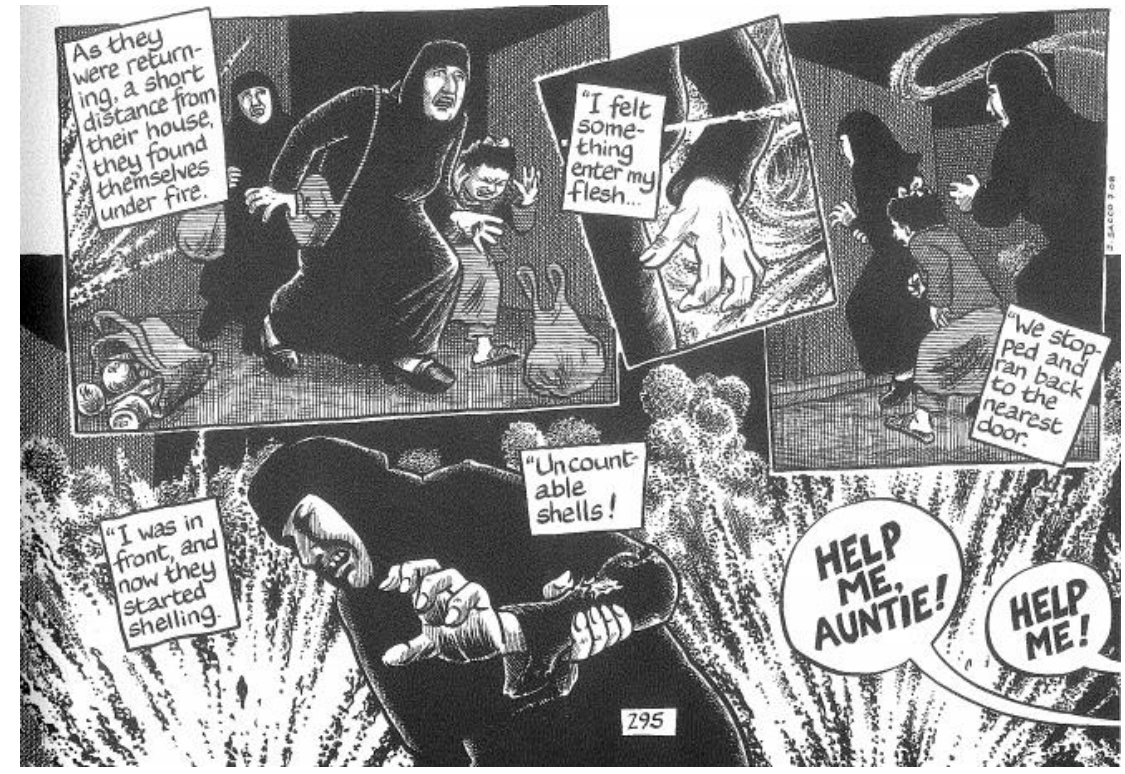

Figura 23. Shells and shelling (SACCO, 2009, p.295)

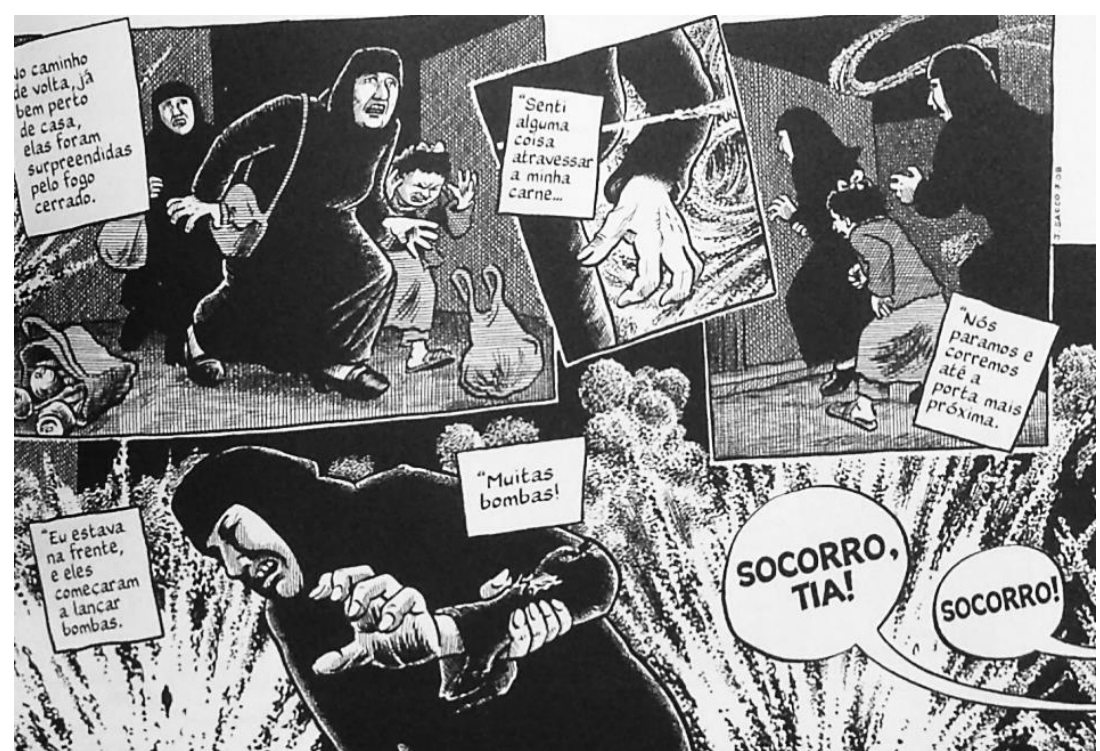

Figura 24. Lançar bombas, muitas bombas (SACCO, 2010, p.295) 


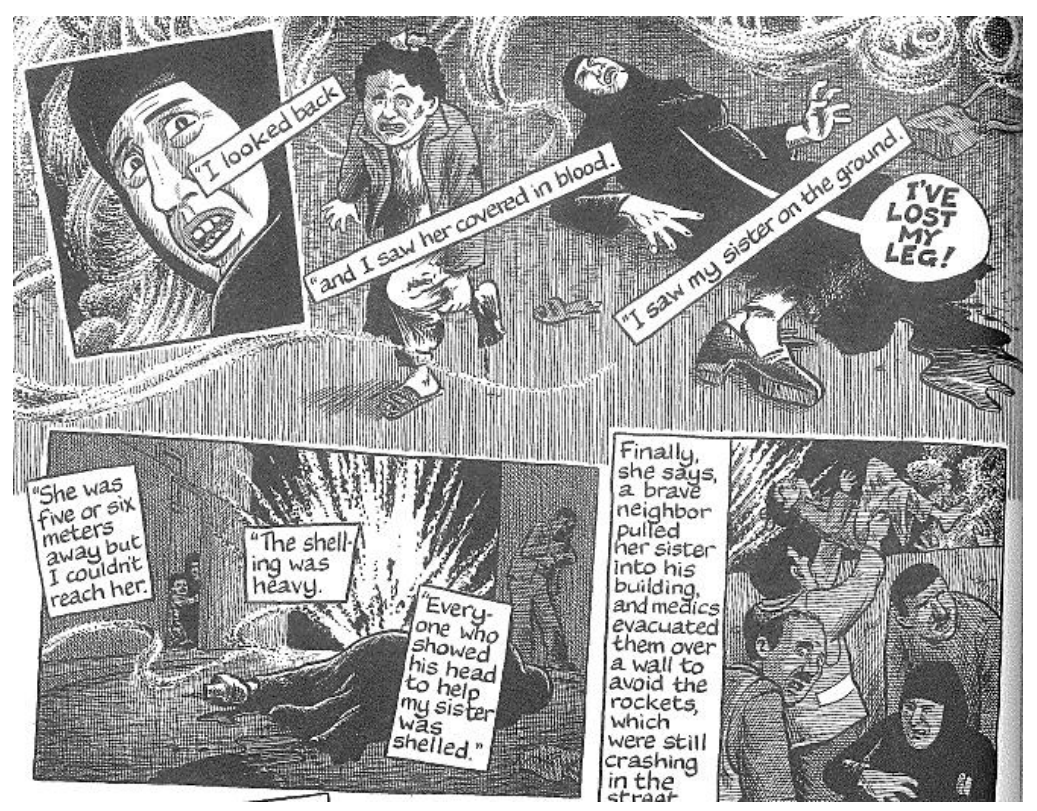

Figura 25. Shelling, shelled (SACCO, 2009, p.296)

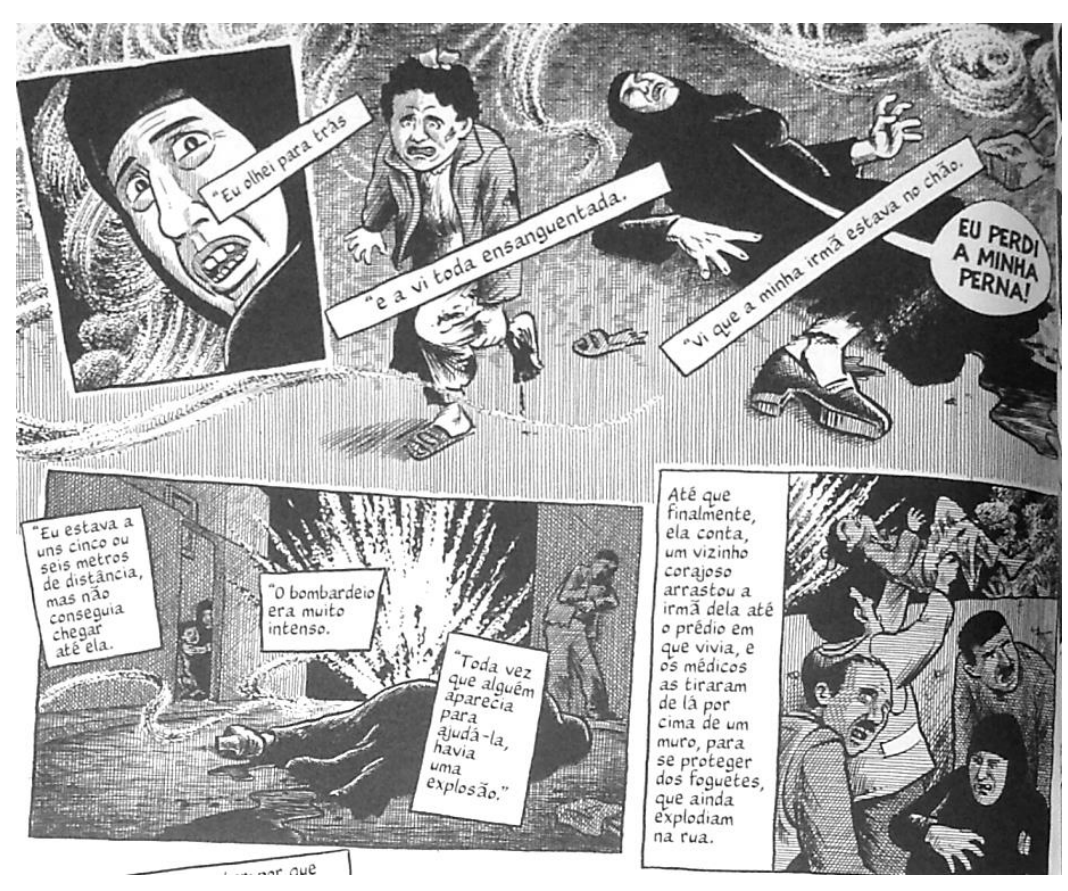

Figura 26. Bombardeio, explosão (SACCO, 2010, p.296) 
Tabela 7

\begin{tabular}{|l|l|}
\hline \multicolumn{1}{|c|}{ Texto em inglês } & \multicolumn{1}{|c|}{ Texto em português } \\
\hline $\begin{array}{l}\text { "I was in front, and now they started } \\
\text { shelling." (grifo meu) }\end{array}$ & $\begin{array}{l}\text { "Eu estava na frente, e eles começaram a } \\
\text { lançar bombas." (grifo meu) }\end{array}$ \\
\hline "Uncountable shells!" (grifo meu) & "Muitas bombas!" (grifo meu) \\
\hline "The shelling was heavy." (grifo meu) & "O bombardeio era muito intenso." (grifo \\
meu)
\end{tabular}

A sequência de imagens sombrias e a lembrança narrada por Fatiah formam uma composição bombástica. A intensidade da narrativa se expressa em ambos os códigos, mas a repetição e a cadência de "shell" e suas variações acrescentam um caráter literário a essa memória. Assim, a tradução, de acordo com seu propósito de ser uma obra legitimada e diferenciada, tem que reproduzir o efeito literário, recriando os mecanismos na língua de chegada.

A marcação de "shelling", "shells" e "shelled" denota um efeito, como o de bombas atingindo a narrativa no âmbito da palavra. Para reproduzir a marcação em português seria necessário escolher uma palavra que tivesse a gama de possibilidades de "shell". As cenas são muito escuras e não tem como se saber se os ataques eram aéreos ou em solo. Se houvesse uma distinção no tipo de investida, a tradução de "shell" poderia ser mais específica, como tiro, granada ${ }^{74}$, cartucho $^{75}$. No entanto, apesar de ser

\footnotetext{
${ }^{74}$ Termo usado na artilharia.

${ }^{75}$ Fonte: http://www.wordreference.com/enpt/shell Acesso online em 26 de janeiro de 2016.
} 
genérico, o termo "bomba" parece ser uma opção aceitável, dado o fato de que não se tem a referência visual da incursão. Após definir a tradução para o termo, o tradutor teve que buscar manter um paralelismo entre os quadros.

A tradução para "shelling" foi "lançar bombas". A reformulação se dá por meio da transposição de ordem, a palavra "shelling" foi traduzida por "lançar bombas", verbo + substantivo, pertencendo parcialmente à ordem lexical. Para manter a sintonia das repetições, seria possível traduzir "shelling" por "bombardear"; assim, a função gramatical continuaria sendo de verbo. $\mathrm{Na}$ segunda legenda com "shells", a escolha "bombas" serve ao propósito de manter a estilística do autor, conforme foi estabelecido no quadro anterior.

Na terceira legenda, "shelling 76 " foi traduzida como "bombardeio", mantendo o paralelismo com as opções anteriores e a função de substantivo no texto. Na última legenda, o verbo está na voz passiva, "Everyone [...] was shelled", sugerindo que as pessoas se tornavam alvos ao prestarem assistência. Para conseguir passar a mensagem, o tradutor optou por reestruturar a frase e mostrar que as bombas explodiam cada vez que alguém tentasse ajudar, sugerindo uma coincidência devido à intensidade do bombardeio. $\mathrm{O}$ estilo para ser mantido neste caso poderia ter sido recriado com "era bombardeado". Apesar de a raiz "bomba" desaparecer, a palavra "explosão" estabelece uma relação com a imagem. Porém, há uma quebra no fluxo da narrativa espacial que é reforçada de maneira indicial palavra-elemento quadrinhístico.

Fathia continua a conversar com Sacco, mas o tópico da conversa muda. Falam sobre o perigo de se morar na fronteira e como as outras casas foram destruídas também. Nos últimos três quadros da página 296, Fathia tem um semblante triste, cansado e desesperançada. Da mesma forma que "shell" é usada como um mecanismo de ênfase para desencadear um efeito literário, "demolish" é usada como base para repetir esse efeito.

\footnotetext{
${ }^{76}$ Fonte: http://www.oxforddictionaries.com/pt/traduzir/ingles-portugues/shelling Acesso online em 26 de janeiro de 2016.
} 


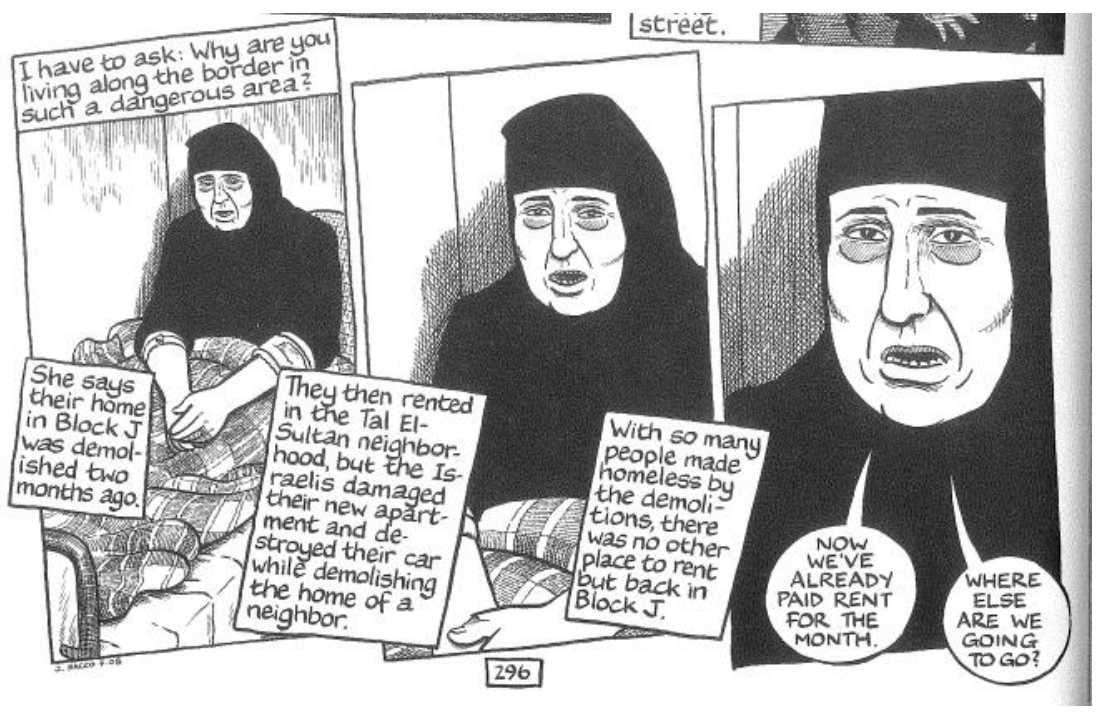

Figura 27. Demolished, demolishing, demolitions (SACCO, 2009, p.296)

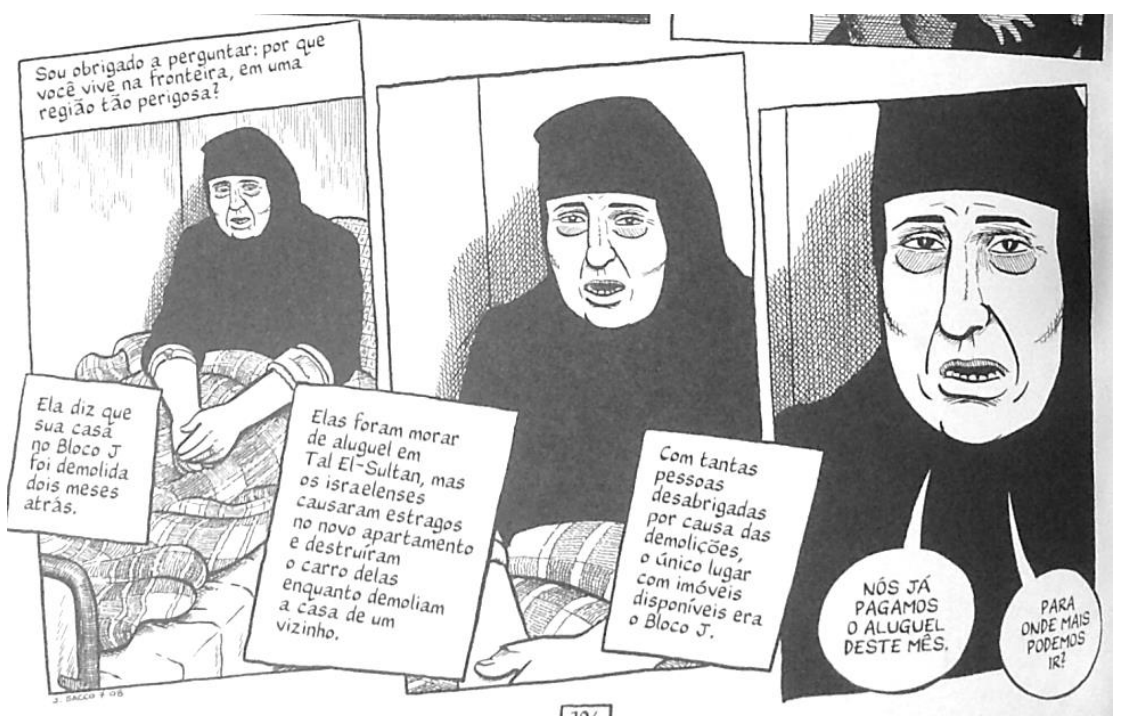

Figura 28. Demolida, demoliam, demolições (SACCO, 2010, p.296)

Tabela 8.

\begin{tabular}{|l|l|}
\hline \multicolumn{1}{|c|}{ Texto em inglês } & \multicolumn{1}{|c|}{ Texto em português } \\
\hline $\begin{array}{l}\text { "She says their home in Block J was } \\
\text { demolished two months ago". (grifo meu) }\end{array}$ & $\begin{array}{l}\text { "Ela diz que sua casa no Bloco J foi } \\
\text { demolida dois meses atrás." (grifo meu) }\end{array}$ \\
\hline "The Israelis $[. .$.$] destroyed their car while$ & "[...] destruíram o carro delas enquanto \\
\hline
\end{tabular}




\begin{tabular}{|l|l|}
\hline $\begin{array}{l}\text { demolishing the home of a neighbor". (grifo } \\
\text { meu) }\end{array}$ & $\begin{array}{l}\text { demoliam a casa de um vizinho". (grifo } \\
\text { meu) }\end{array}$ \\
\hline $\begin{array}{l}\text { "With so many people made homeless by } \\
\text { the demolitions [...]" (grifo meu) }\end{array}$ & $\begin{array}{l}\text { "Com tantas pessoas desabrigadas por causa } \\
\text { das demolições [...]"(grifo meu) }\end{array}$ \\
\hline
\end{tabular}

\subsubsection{A guerra e seus termos}

Notas sobre Gaza é um livro que relata os conflitos na Faixa de Gaza, especificamente os massacres na região de Rafah e Khan Younis em 1956 e os ataques frequentes durante a estadia do jornalista Joe Sacco no período de 2002-2003. A temática, como já mencionado antes, é relevante e atual, pois os conflitos continuam.

Além de entrevistas e conversas com os palestinos sobre os eventos de 56 e a vida cotidiana no início do milênio, Sacco usa fatos, documentos e dados que conseguiu coletar, tanto de Israel, como da Palestina e da UNWRA, a fim de legitimar sua reportagem. Assim, devido aos embates entre israelenses e palestinos e a presença militar constante na região, o léxico relacionado à guerra aparece em várias partes da obra.

Um dos objetivos desta pesquisa é identificar como o vocabulário relacionado a essa temática foi traduzido, levando em consideração que se trata de uma linguagem quadrinizada (relação imagem-texto, limitação de legendas e balões, falas de personagens, etc.). Para isto, alguns termos recorrentes foram selecionados para análise. 


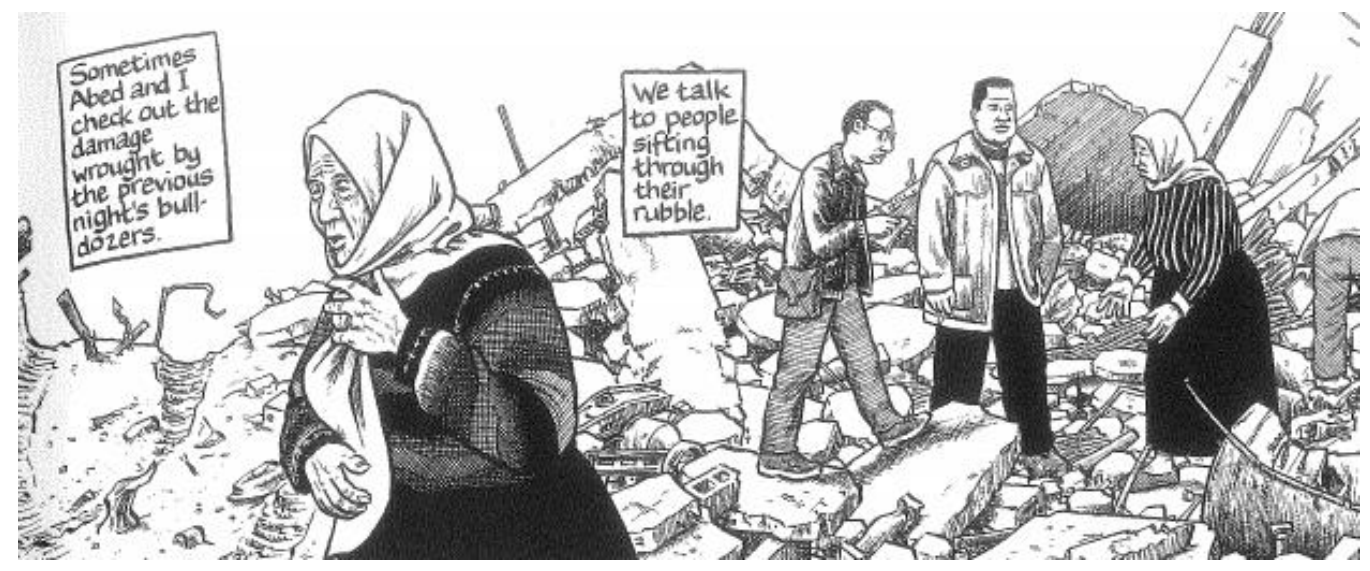

Figura 29. Bulldozers (SACCO, 2009, p.17)

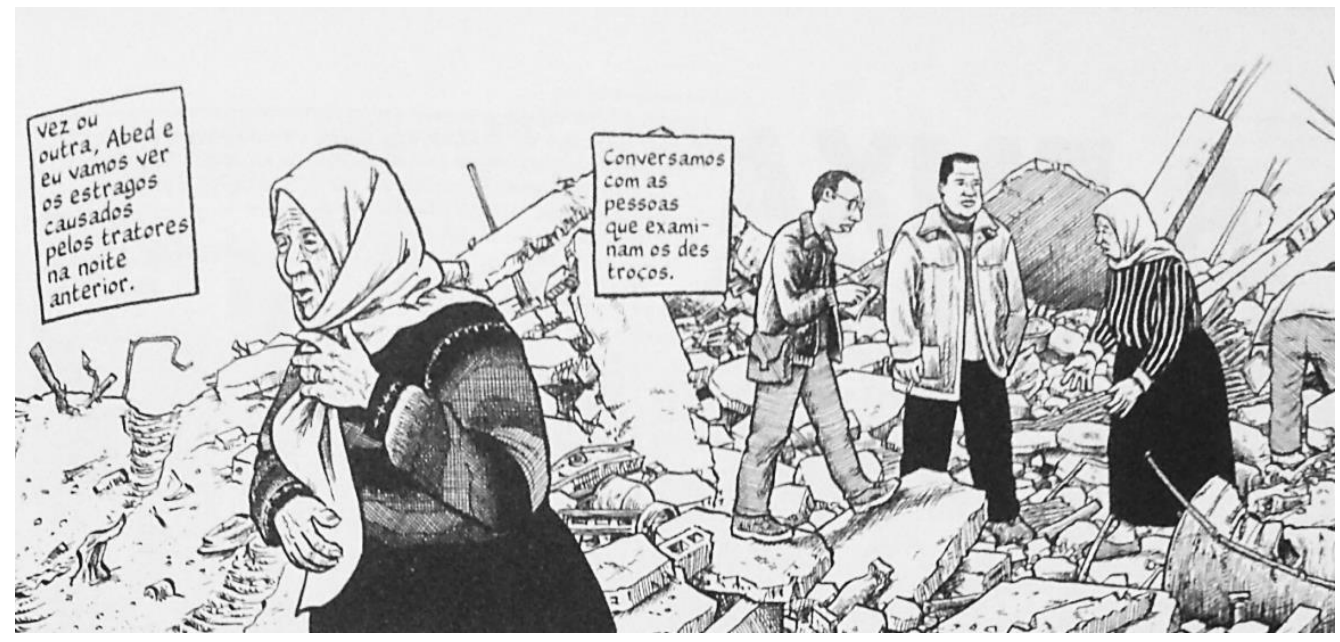

Figura 30. Tratores (SACCO, 2010, p.17)

\begin{tabular}{|l|c|c|c|}
\hline \multicolumn{3}{|c|}{ TERMO SELECIONADOS } \\
\hline \multicolumn{2}{|c|}{ Texto de Partida (inglês) } & $\begin{array}{c}\text { Texto de Chegada } \\
\text { (português) }\end{array}$ & Termos técnicos \\
\hline p. 17 & bulldozer & tratores & tratores de lâmina \\
\hline
\end{tabular}




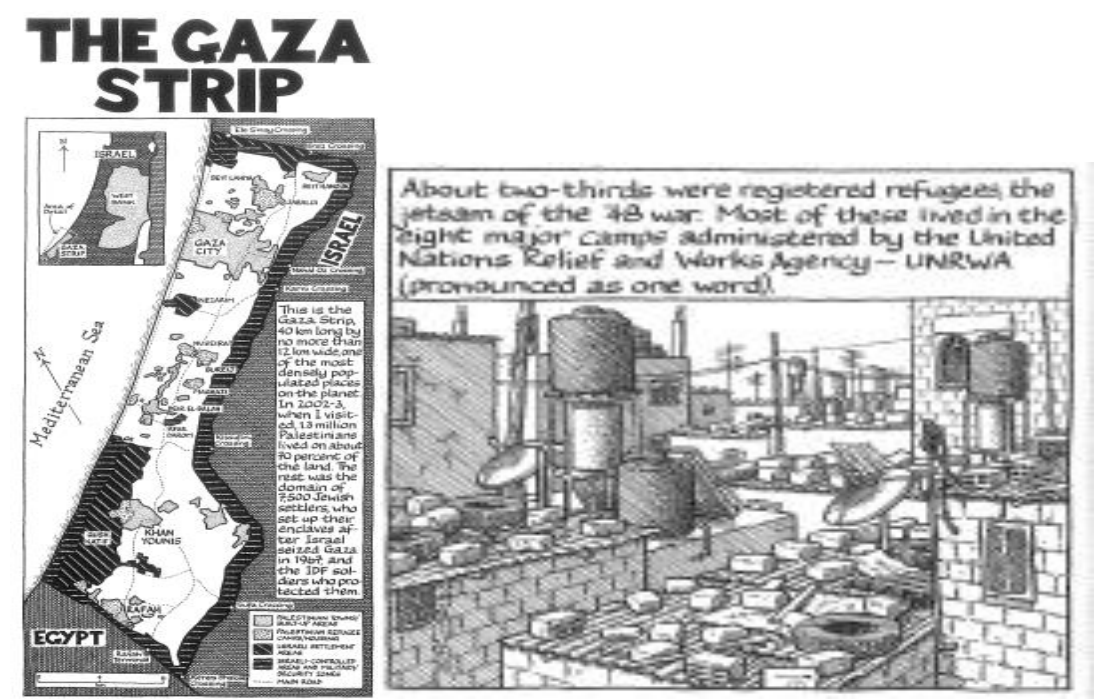

Figura 31. Enclaves, IDF and UNWRA (pronounced as one word) (SACCO, 2009, p.18)

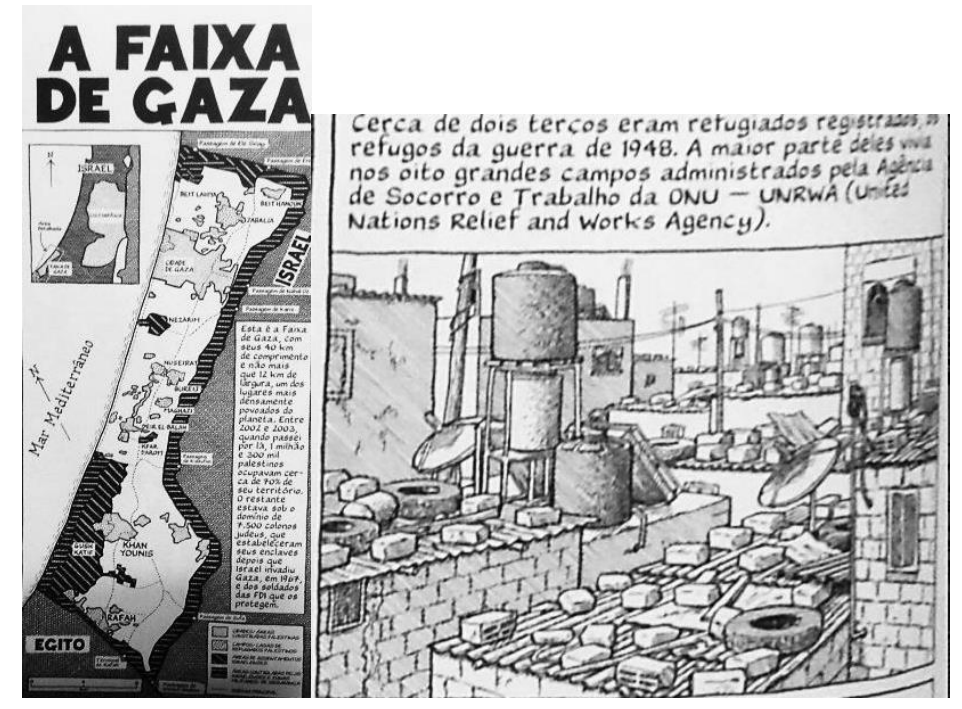

Figura 32. Enclaves, FDI e UNWRA (SACCO, 2010, p.18)

\begin{tabular}{|l|c|c|c|}
\hline \multicolumn{3}{|c|}{ TERMOS SELECIONADOS } \\
\hline \multicolumn{2}{|c|}{ Texto de Partida (inglês) } & $\begin{array}{c}\text { Texto de Chegada } \\
\text { (português) }\end{array}$ & Termos técnicos \\
\hline p. 18 & enclaves & enclaves & enclaves \\
\hline
\end{tabular}




\begin{tabular}{|c|c|c|c|}
\hline IDF & FDI & FDI $^{77}$ \\
\cline { 2 - 4 } & United Nations Relief and & Agência de Socorro e & Agência das Nações \\
Works Agency - UNRWA & Trabalho da ONU - & Unidas de Assistência \\
& (pronounced as one word) & UNRWA (United & aos Refugiados da \\
& Nations Relief and & Palestina (UNRWA) \\
& & Works Agency) & \\
\hline
\end{tabular}

\begin{tabular}{|c|c|c|c|}
\hline \multicolumn{4}{|c|}{ TERMOS SELECIONADOS } \\
\hline \multicolumn{2}{|c|}{ Texto de Partida (inglês) } & Texto de Chegada & Termos técnicos \\
\hline \multirow[t]{2}{*}{ p.19 } & checkpoints & pontos de verificação & $\begin{array}{l}\text { barreira alfandegária }^{79} \\
\text { ponto de inspeção }^{80}\end{array}$ \\
\hline & headquarters & quartel-general & comando, sede, quartel- \\
\hline
\end{tabular}

\footnotetext{
${ }^{77}$ FDI é a abreviação para Forças de Defesa de Israel. Fonte: http://embassies.gov.il/Lisboa/AboutIsrael/State/Pages/ESTADO-FDI.aspx Acesso online em 23 de fevereiro de 2016.

${ }^{78}$ Termo usado em português pela agência. Fonte: http://unrwa.org.br/sobre a unrwa/ Acesso online em 23 de fevereiro de 2016.

79 O termo checkpoint é traduzido como "ponto de verificação" quando se trata de um item em uma lista de afazeres, de acordo com o dicionário Word Reference. Fonte:

http://www.wordreference.com/enpt/checkpoint Acesso online em 23 de fevereiro de 2016.

${ }^{80}$ Entrada como verbete de segurança. Fonte: http://www.oxforddictionaries.com/pt/traduzir/inglesportugues/checkpoint Acesso online em 23 de fevereiro de 2016.
} 


\begin{tabular}{|c|c|c|c|}
\hline & & & sede, QG \\
\hline & command post & posto de comando & posto de comando \\
\hline & ambushes... booby trap & emboscadas...armadilhas & $\begin{array}{c}\text { emboscada... } \\
\text { armadilha }\end{array}$ \\
\hline p. 38 & chief of staff & comandante do exército & chefe de estado-maior \\
\hline & retaliation & retaliação & retaliação, represália \\
\hline & strike & castigar & $\begin{array}{l}\text { desarmar (tents); } \\
\text { levantar (camp); } \\
\text { golpear, bater, atirar }\end{array}$ \\
\hline
\end{tabular}

Os termos selecionados apresentam alguma relação com as esferas militar, política e das relações exteriores. Como visto, os termos tendem a serem traduzidos de acordo com o contexto, levando em consideração a terminologia existente em ambas as línguas.

O termo "bulldozer", que tem como termo em português "trator de lâmina", foi traduzido por "trator", omitindo a segunda parte devido ao espaço limitado, porém sem alterar o conteúdo e sentido da frase. Alguns termos em inglês têm mais do que um equivalente em português; assim, fica a critério do tradutor de quadrinhos analisar o espaço disponível, o número de caracteres, a relação imagem-texto e o contexto que se encontra a palavra.

A sigla UNWRA foi traduzida de forma literal, porém a explicação da palavra foi substituída pelo nome em inglês. É possível que quando o texto foi traduzido o sítio da UNWRA não havia sido criado em português. Entretanto, seria interessante ressaltar 
na tradução que é uma organização destinada somente aos palestinos; uma agência que foi criada para auxiliar e cooperar com as instituições locais.

Apesar de algumas opções terem sido diferentes da terminologia conhecida, o tradutor busca manter a coesão e a coerência com as suas escolhas, usando, quando apropriado, sinônimos e outras conotações para os termos. O tamanho restrito das legendas guia o tradutor em quais opções são mais adequadas para o texto não ficar mais extenso do que o original. Boide explica que

Como existe um espaço limitado para o texto em boxes e balões, é preciso estar atento para a tradução não ficar muito maior que o texto original, pois nesse caso acaba não cabendo no espaço delimitado. Na obra de um autor como Joe Sacco, manter a concisão é fundamental (Entrevista com Alexandre Boide, janeiro de 2016, anexo).

\subsubsection{Tradução e ironia}

A tradução segue o projeto da obra, apresentando, quando necessário, por meio da explicitação, as características culturais, sociais e históricas no código verbal. Ao longo da narrativa, Sacco consegue passar por meio da ironia questionamentos que vão além da sua pesquisa de campo. No início de sua narrativa, ele mostra um pouco da sua rotina em Tel Aviv e começa a apontar para o leitor as diferenças entre duas realidades que coexistem ao meio de bombas e ataques.

No decorrer do primeiro capítulo, Sacco questiona o comportamento indiferente de repórteres internacionais que cobrem os acontecimentos na Faixa de Gaza. Por meio da imagem, ele ironiza a mesmice das notícias do conflito Israel-Palestina. Um simples cardápio se torna a projeção dos ataques constantes, pratos que podem ter sido servidos no ano retrasado, mês passado ou mesmo no dia anterior (Figuras 16a e 16b). Quem notaria a diferença se uma notícia antiga fosse replicada como algo inédito? Explosões, assassinatos, ataques, incursões, tiroteios são sempre os mesmos pratos do cardápio. 


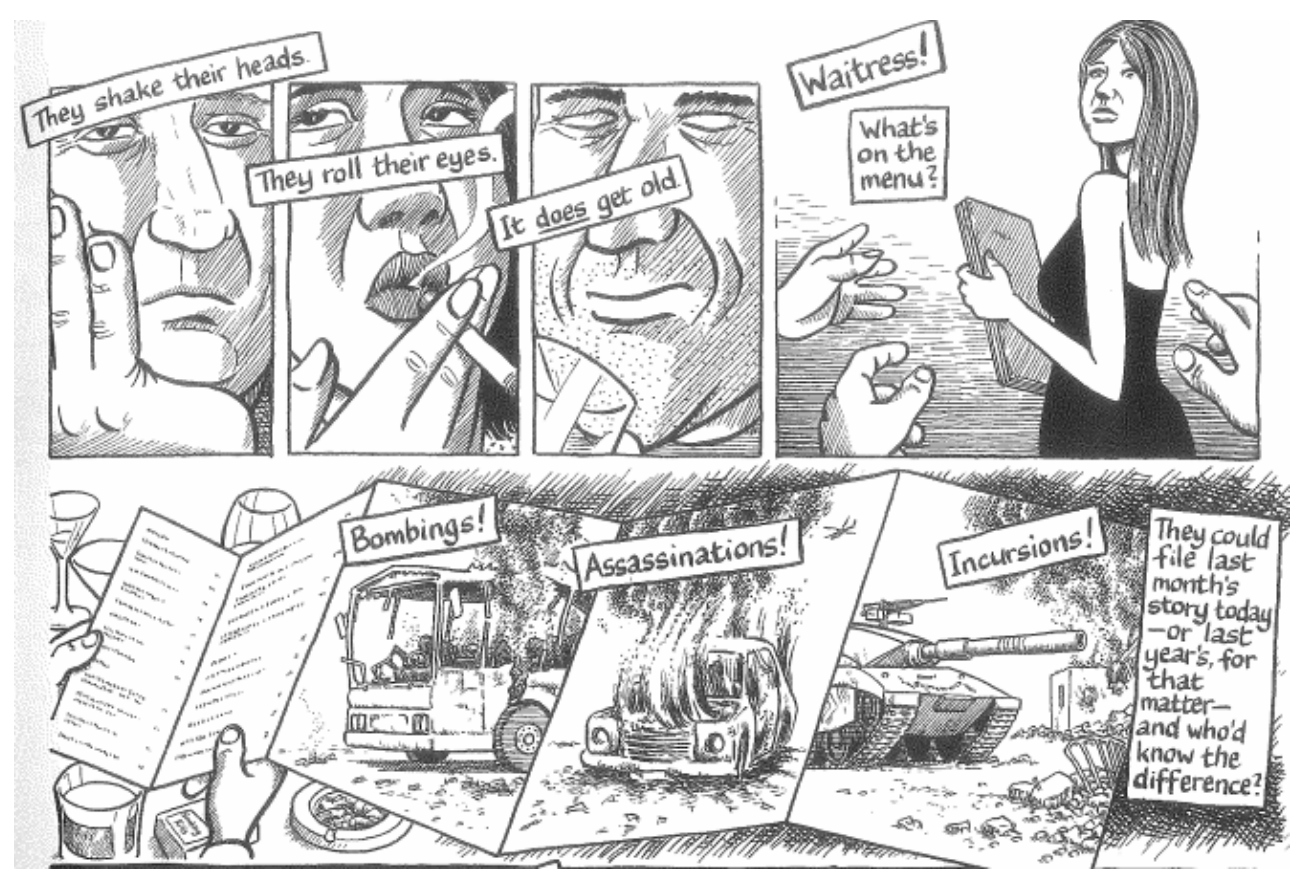

Figura 16a. Menu

Fonte: Footnotes in Gaza (SACCO, 2009, p.5)

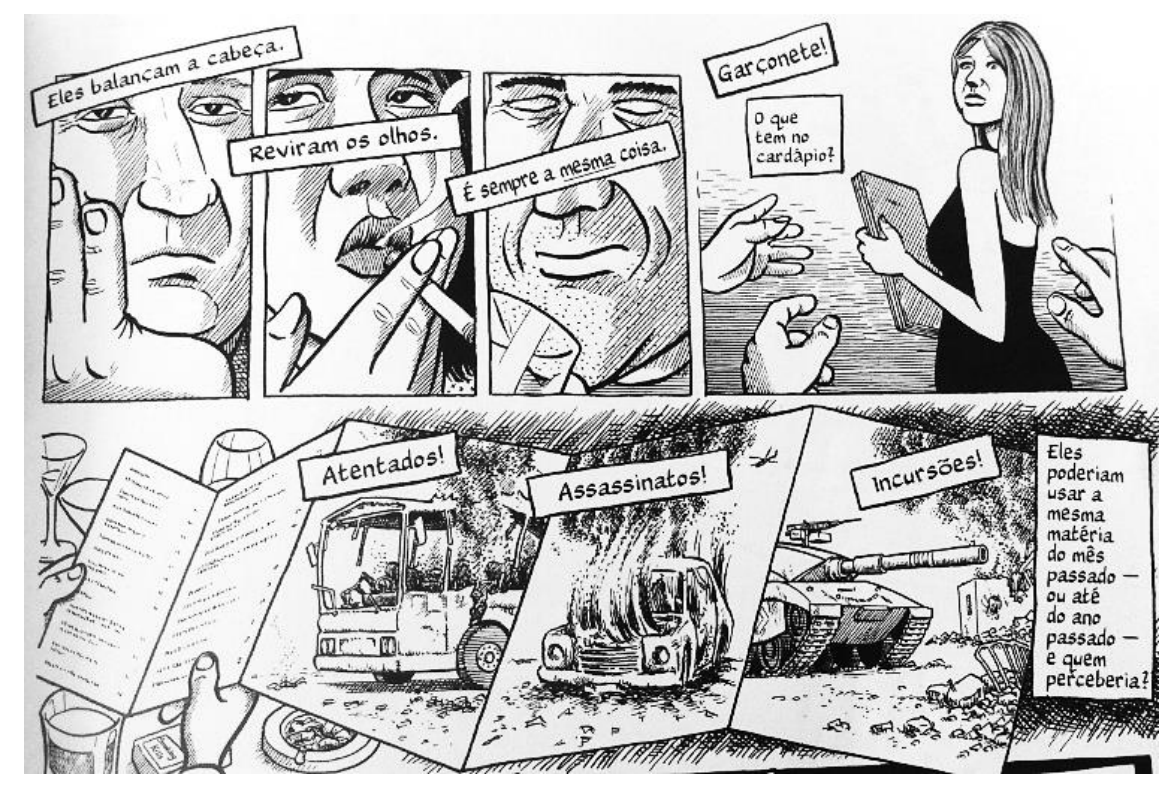

Figura 16b. Cardápio de atentados

Fonte: Notas sobre Gaza (SACCO, 2010, p.5) 
O texto é repleto de marcas de ironia. Sacco contrasta a visão entre a realidade oriental e ocidental. Os jornalistas procuram novas histórias, novos conflitos, novos números de mortos, mas para os palestinos a realidade é sempre a mesma. $\mathrm{O}$ medo continua. $\mathrm{O}$ desespero está sempre presente. A raiva e a indignação nunca cessam. Sacco consegue transmitir o ponto de vista de muitos representantes de emissoras internacionais com o jogo de imagens, figurando matérias de jornal como pratos de um restaurante.

A tradução da ironia nesta passagem ocorre com a tradução literal nos primeiros dois quadros, no terceiro quadro a recriação de "It does get old" é feita com "É sempre a mesma coisa", com ênfase na palavra "mesma", mostrando que as notícias novas são as mesmas notícias de sempre, e nos quadros seguintes, a tradução literal é usada novamente nos termos "atentados", "assassinatos" e "incursões".

Nos quadrinhos, a ironia é aumentada devido à sobreposição de modos que pode ser explorada. Isso faz com que diferentes níveis de sensibilidade e informações sejam acionadas pelo contraste de interpretações, como na figura acima.

A ironia presente no JHQ de Sacco provoca um efeito diferente de outros meios de comunicação por causa dos mecanismos que os diferentes níveis de informação presente nos quadrinhos ativam durante a leitura.

O autor consegue fazer com que a relação imagem-texto sirva não somente ao propósito de questionar a motivação da cobertura internacional em Gaza, como também para correlacionar fatos. Em outros momentos da narrativa, Sacco brinca com seus amigos palestinos que vai atirar neles, demolir suas casas e outras atrocidades que fazem parte da rotina de Gaza.

\subsubsection{Casamento entre imagem e texto}

A imagem e o texto nos quadrinhos dialogam em diferentes níveis na narrativa sequencial. A tradução de HQs está subordinada à imagem, uma vez que ela não pode 
ser alterada. Assim, a criatividade entra em jogo para recriar a conexão prévia no texto de partida.

Notou-se em alguns casos que o texto traduzido se utilizou do signo visual para, então, usar o signo verbal na tradução. As ilustrações podem ser uma das limitações para a recriação do texto em outra língua, mas diversas vezes elas servem de auxílio para o tradutor. Alguns exemplos foram tirados de vários capítulos da obra.

No capítulo Celebração, quando o açougueiro e seu filho estão fazendo o sacrifício do boi (p.141), o tradutor optou por transformar uma referência que estava no plural, tanto na imagem quanto no texto, para o singular. Uma opção que não contradiz completamente a cena, pois a visualização permite que seja só uma das mãos ou as duas (Figuras 17a e 17b).

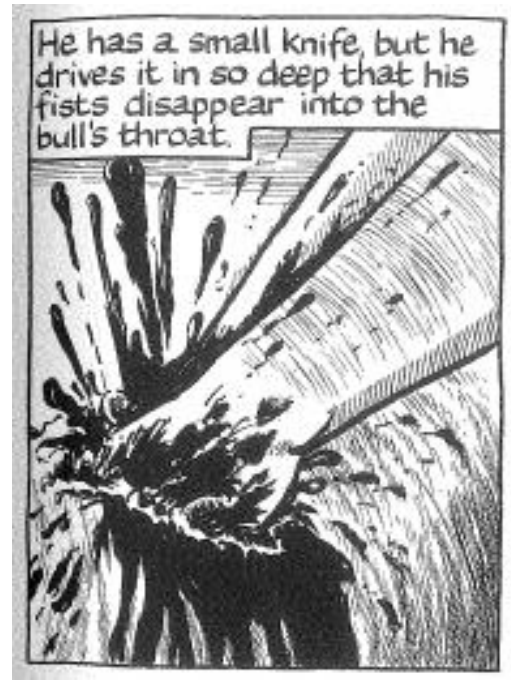

Figura 17a. Punho

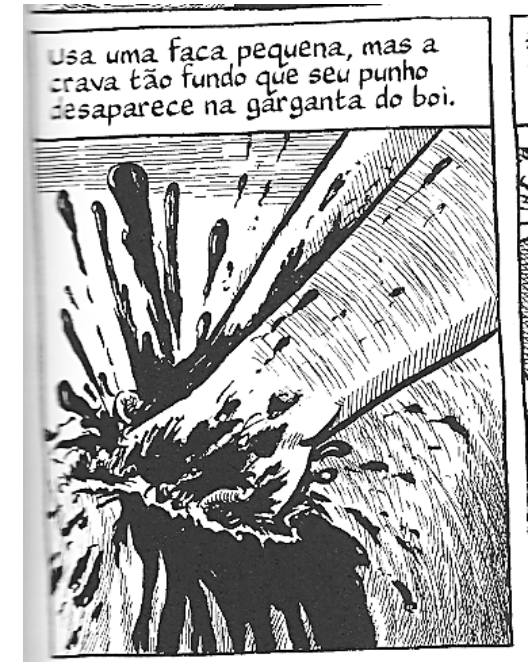

Figura 17b. Punhos

O último quadro (Figuras 18a e 18b) é marcado pela relação da imagem-texto. A ressignificação passa de "não vistos acima" (unseen overhead) para "acima das nuvens". O temporal marcado pelas nuvens densas e pesadas ajuda o tradutor a recriar o texto com base na imagem.

Os desenhos obscuros em preto e branco saltam da página e as legendas em fundo completamente branco funcionam como pequenas notas que lembram o leitor que 
as imagens contam uma história muito além do que possa ser representado. Ao final da celebração, Sacco e Abed voltam para casa e uma chuva torrencial cai no último quadro. Era uma chuva bastante esperada. O tracejado sombrio da chuva forma um paralelo com a descrição dos bombardeios na segunda legenda:

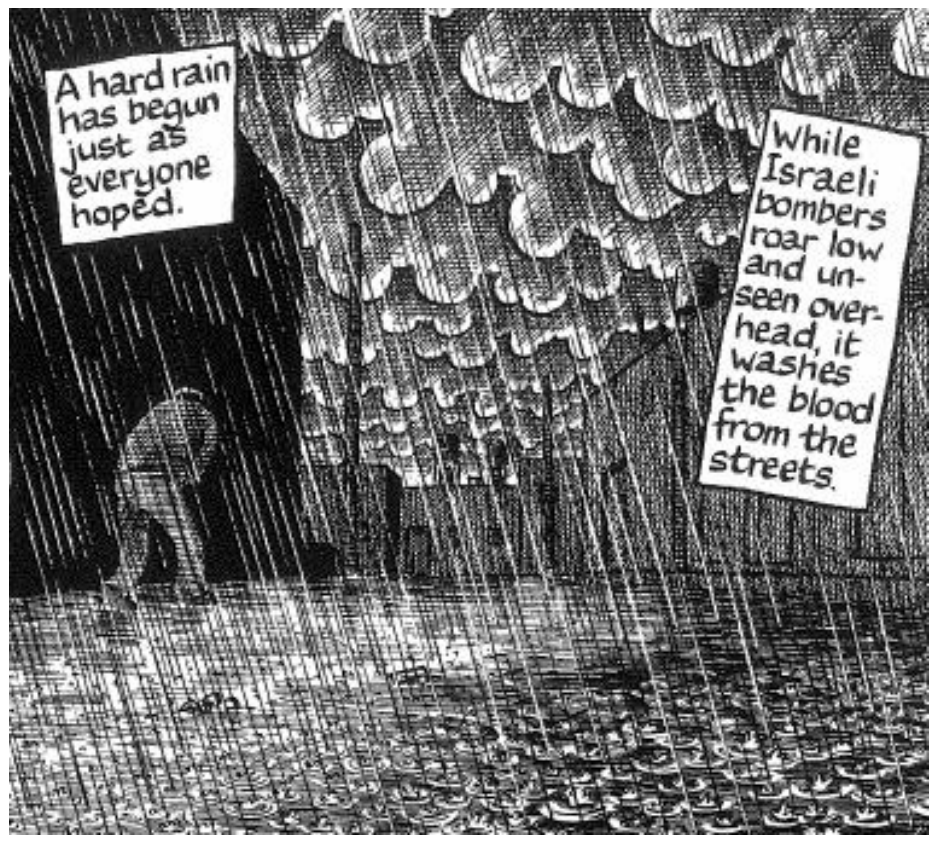

Figura 18a. Nuvens, chuva e sangue

Fonte: Footnotes in Gaza (SACCO, 2009, p.145)

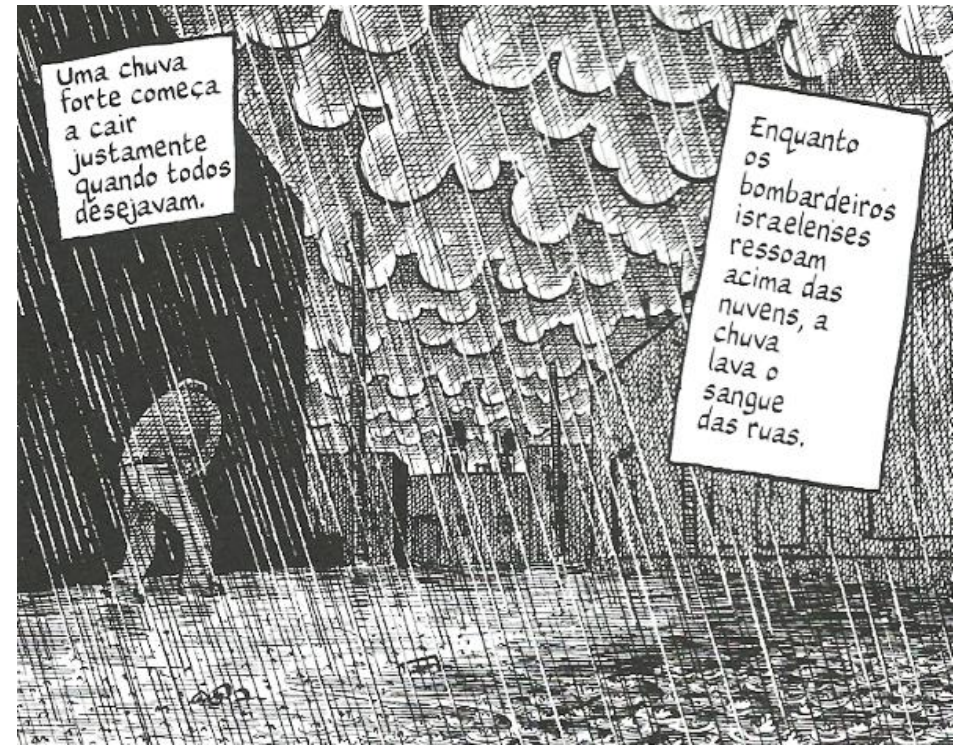

Figura 18b. Nuvens, chuva e sangue

Fonte: Notas sobre Gaza (SACCO, 2009, p.145) 
Tabela 7

\begin{tabular}{|l|l|}
\hline \multicolumn{1}{|c|}{ Texto em inglês } & \multicolumn{1}{|c|}{ Texto em português } \\
\hline $\begin{array}{l}\text { "While Israeli bombers roar low and } \\
\text { unseen overhead, it washes the blood from } \\
\text { the streets." (grifo meu) }\end{array}$ & $\begin{array}{l}\text { "Enquanto os bombardeiros israelenses } \\
\text { ressoam acima das nuvens, a chuva lava o } \\
\text { sangue das ruas." (grifo meu) }\end{array}$ \\
\hline
\end{tabular}

A referência ao som distante é traduzida como "ressoam", deixando de lado o tom ameaçador de "roar" - rugir. Há o destaque na mudança de "unseen overhead" para "acima das nuvens". A reestruturação e a ressignificação desta passagem costuram os pontos dados em várias partes da narrativa. Os aviões, helicópteros e drones não podem ser vistos acima das nuvens, muito menos sob uma forte chuva. Sabe-se que eles estão lá por causa do barulho. Marcar as "nuvens" na tradução dirige a atenção do leitor para a ilustração e destaca a obscuridade da cena devido à chuva.

A palavra "chuva", na segunda legenda, poderia ter sido substituída por "ela", mas a repetição atrai o leitor para a multiplicidade de elementos presentes no texto: 1) a chuva era esperada, e 2) a chuva lava o sangue das ruas, 3) a chuva abafa o som dos veículos aéreos e 4) a chuva impede que os israelenses tenham a visualização da área. Por mais sombria que seja a vinheta, o signo "chuva" dialoga com a imagem e reforça a ligação entre texto e imagem. Além disso, traz outra referência: o sangue lavado é dos bois que foram sacrificados, mas entende-se que também das milhares de vidas perdidas por causa dos constantes conflitos. Os diferentes níveis de interpretação que a multimodalidade dos quadrinhos ativa na leitura abrem espaço para outras acepções de "nuvens", "chuva" e "sangue". 


\section{CONCLUSÃO}

A presente pesquisa buscou analisar, com embasamento teórico na linguagem dos quadrinhos e teorias da tradução, as estratégias e os mecanismos usados para recriar a sensibilidade no texto traduzido para o português.

O foco principal dessa pesquisa era identificar os aspectos linguísticos que influenciaram a natureza sensível do texto, levando em consideração a alteridade, a religião, a cultura e outros fatores presentes na narrativa. Além disso, a linguagem específica das HQs, que combina os códigos visual e verbal para construir uma forma singular, demonstrando que o tradutor de quadrinhos não depende somente ao texto escrito nas legendas, balões de fala, recordatórios e onomatopeias.

Os resultados obtidos após a análise crítica da tradução nos levaram a concluir que a tradução do jornalismo em quadrinhos implica a alusão a outros meios, isto é cinema, fotografia, jornal, e é determinada de acordo com o projeto de tradução. A transcriação do estilo do autor, bem como de aspectos marcados e não-marcados no texto fonte indicam os propósitos estabelecidos para a funcionalidade do texto traduzido.

Com a análise de Notas sobre Gaza, foi possível identificar, a autonomia do tradutor em reproduzir o tom, as nuances e a tensão relacionada à temática e demais aspectos (extra)linguísticos do texto de partida. Além disso, foi possível apontar os procedimentos tradutórios, que o tradutor, Alexandre Boide, adotou em português para reconstituir as particularidades da obra. Suas escolhas evidenciam um alinhamento com o estilo do autor, uma preocupação com a funcionalidade da tradução e a legitimação da obra no Brasil.

O caráter sensível de reportagens quadrinizadas ainda não é amplamente estudada dentro dos Estudos da Tradução. Porém, outros itens importantes para a construção de sentido na narrativa multimodal têm bastante destaque, como a relaçãoimagem texto, aspectos da oralidade fingida, alusões e inferências culturais, a tradução de humor, entre outros. 
Portanto, o uso de uma linguagem convencionada, como a dos quadrinhos, em que a relação entre signos icônicos e simbólicos é indissociável, permite que a análise crítica da tradução não seja limitada a questões isoladas das línguas envolvidas.

A tradução desempenha uma função comunicativa importante ao colocar as línguas em contato. Nesse sentido, pesquisar as estratégias de tradução de um subgênero específico, como o do JHQ, pretende fornecer estímulos para futuras análises críticas de tradução criativa que não se limitem à tradução literária.

Com um aporte funcionalista, a análise crítica da tradução objetiva a liberdade, a criatividade e independência do tradutor em relação ao texto original. A noção de fidelidade e lealdade ao texto de partida é substituída à fidelidade aos propósitos, intenções e funções que o texto de chegada busca satisfazer. 


\section{REFERÊNCIAS BIBLIOGRÁFICAS}

ALMEIDA, Cláudia Suzano de. Legendas e intermediação: humor e sensibilidade em tradução. 2015. 167 páginas. Dissertação de mestrado. Programa de Pós-graduação em Estudos da Tradução, UnB, Brasília.

ABIDIN, Danial Zainal. Islam the misunderstood religion. Kuala Lumpur: PTS Millenia, 2012.

BARBOSA, Heloísa Gonçalves. Procedimentos técnicos da tradução: Uma nova proposta. $2^{\mathrm{a}}$ ed. Campinas: Pontes, 2004.

BATALHA, Maria Cristina; PONTES, Geraldo Ramos. A tradução como prática da alteridade. Cadernos de Tradução, Florianópolis, v. 1, n. 13, p. 27-43, jan. 2004.

BENJAMIN, Walter. A tarefa do tradutor. In: Escritos sobre mito e linguagem. São Paulo: editora 34, 2011, p. 101-119.

BOIDE, Alexandre. Entrevista. [jan. 2015]. Entrevistador: Gabriela Cristina Teixeira Netto do Nascimento. Brasília, 2015. 1 arquivo .doc. A entrevista na íntegra encontra-se transcrita no Anexo desta dissertação.

BRAGA, Ana Cláudia Vieira. Norma linguística e oralidade fingida na tradução de Persépolis. 2013. 107 páginas. Dissertação de Mestrado. Programa de Pós-graduação em Estudos da Tradução, UnB, Brasília.

CAGNIN, Antonio Luiz. Os quadrinhos: linguagem e semiótica. $1^{\text {a }}$ ed. São Paulo. Criativo, 2004.

CELOTTI, Nadine. The translator of comics as a semiotic investigator. In: Comics in translation. (Org.) ZANNETIN, Federico. 2008.

CHINEN, Nobu. Linguagem HQs: conceitos básicos. São Paulo: Criativo, 2015.

COSTA, Fernanda de Oliveira Marconi da. O uso dos diminutivos no cotidiano da língua portuguesa. Cadernos do CNLF, v. 7, n.10, 2003. 
DRUMMOND, Bárbara. Notas de rodapé em Gaza: o jornalismo em quadrinhos de Joe Sacco. 2010. Trabalho de Conclusão de Curso. Departamento de Letras Estrangeiras e Tradução, UnB, Brasília.

ECO, Umberto. Apocalípticos e integrados. São Paulo: Perspectiva, 1979. [Debates, 19]

EISNER, Will. Quadrinhos e arte sequencial: princípios e práticas do lendário cartunista. (Trad. BOIDE, Alexandre; BORGES, Luis Carlos.) São Paulo: WMF Martins, 2012.

GADAMER, Hans-Georg. De: Verdade e método. In: Clássicos da teoria da tradução: antologia bilíngue, volume 1, alemão-português. $2^{\mathrm{a}}$ ed. UFSC: Florianópolis, 2010, pp. 235-251.

GERONIMO, Vanessa. A teoria da transcriação de Haroldo de Campos: o tradutor como recriador. Qorpus, n.13, jun. 2010.

GOETHE, Johann Wolfgang Von. Três trechos sobre tradução. In: Clássicos da teoria da tradução: antologia bilíngue, volume 1, alemão-português. $2^{\mathrm{a}}$ ed. UFSC: Florianópolis, 2010, pp. 29-37.

GOMES, Iuri Barros. Jornalismo em quadrinhos: mediações e linguagens imbricadas nas reportagens Palestina - Uma nação ocupada em O fotógrafo. 2010. 102 páginas. Dissertação de mestrado. Programa de Pós-graduação em Estudos de Cultura Contemporânea, Universidade Federal do Mato Grosso, Cuiabá.

JUNEAU, Thomas; SUCHAROV, Mira. Narratives in pencil: using graphic novels to teach Israeli-Palestinian relations. International Studies Perspectives, v.11, pp.172$183,2010$.

LEAL, A. Funcionalismo e tradução literária: o modelo de Christiane Nord em três contos ingleses contemporâneos. Scientia Traductionis, n.2, 2006.

LIBERATTI, Elisângela. Ara, Chico; Aw, Chuck: uma tradução funcionalista de quadrinhos do Chico Bento. 2012. 166 páginas. Dissertação de mestrado. Programa de Pós-graduação em Estudos da Tradução, UFSC, Florianópolis. 
LIMA, Marcelo Oliveira; ROSSONI, Igor. O jornalismo em quadrinhos e os procedimentos jornalísticos em Uma história em Sarajevo. In: CONGRESSO BRASILEIRO DE CIÊNCIAS DA COMUNICAÇÃO, 34, Recife, 2011. Anais. São Paulo: Intercom, 2011.

MAHER, Brigid. Drawing blood: translation, mediation, and conflict in Joe Sacco's comics journalism. In: The comics of Joe Sacco: journalism in a visual world. University Press of Mississippi, 2015.

MATEO, Marta. A Tradução da ironia. Cadernos de Tradução, Florianópolis, v. 1, n. 25 , p. 197 , set. 2010 .

MCCLOUD, Scott. Desvendando os quadrinhos. São Paulo: M. Books, 2004.

MUANIS, F. Imagem, cinema e quadrinhos: linguagens e discurso de cotidiano. Caligrama, v.2, n.1, 2006.

NEGRI, Ana Camilla. Um novo gênero jornalístico: a reportagem em quadrinhos de Joe Sacco. In: CONGRESSO BRASILEIRO DE CIÊNCIAS DA COMUNICAÇÃO, 26, Belo Horizonte, 2003. Anais. São Paulo: Intercom, 2003.

NORD, Christiane. Defining translation functions: the translation brief as a guideline for the trainee translator. Ilha do Desterro, Florianópolis, n.33, pp. 41-55, 1997.

. Translating as a purposeful activity: a prospective approach. TradTerm, São Paulo, v. 11, 2005, pp. 15-28.

Translating as a purposeful activity: functionalist approaches explained. [Translation Theories Explained] Nova York: Routledge, 2014.

OLIVEIRA, Ana Paula Silva; PASSOS, Mateus Yuri. Joe Sacco: Jornalismo Literário em quadrinhos. In: Congresso Brasileiro de Ciências da Comunicação, 29, 2006, Brasília. Anais. São Paulo: Intercom, 2006.

OLIVEIRA, Carla Maria de Oliveira. Gradação de afetividade nos formativos -inho(a) e -zinho(a) a partir do estudo de gramaticalização. Revista Icarahy, Rio de Janeiro, n.2, Dossiê Língua, fev. 2010. 
RAMOS, Paulo. A leitura dos quadrinhos. $2^{\text {a }}$ ed. São Paulo: Editora Contexto, 2011.

Estratégias de referenciação em textos multimodais: uma aplicação em tiras cômicas. Linguagem em (Dis)curso, Tubarão, SC, v. 12, n. 3, p. 743-763, set/dez, 2012 (a).

. Revolução do gibi: a nova cara dos quadrinhos no Brasil. São Paulo: Devir, 2012 (b).

REISS, Katherine; VERMEER, Hans. Towards a general theory of translational action: skopos theory explained. Manchester: St. Jerome, 2013.

RÓNAI, Paulo. Escola de tradutores. 6. ed. rev. ampl. Rio de Janeiro: Nova Fronteira, 1987.

ROSA, Gisele Marion. A tradução quadrinhística: sinais de conflito entre imagem e texto. Tradterm, São Paulo, [S.I.], v.16, pp. 411-434, jun. 2010.

SACCO, Joe. Footnotes in Gaza. Londres: Jonathan Cape, 2009.

Notas sobre Gaza. São Paulo: Quadrinhos na Cia, 2010. Joe Sacco, criador do jornalismo em quadrinhos, fala sobre como escolheu

sua carreira. Entrevista para o Guia do Estudante. 2011. http://guiadoestudante.abril.com.br/blogs/divirta-estudando/um-bate-papo-com-joesacco-o-criador-do-jornalismo-em-quadrinhos/ Acesso online: 10 de fevereiro de 2016.

SANTAELLA, Lúcia. Semiótica aplicada. São Paulo: Pioneira Thomson Learning, 2002.

Matrizes da linguagem e pensamento - Sonora, visual, verbal. São Paulo: Iluminuras, 2005.

SANTOS, Evaldo Gondim. Tradução e ironia: o cientificismo iluminista em Gulliver's Travels vs. (As) Viagens de Gulliver. 2008. 118 páginas. Dissertação de mestrado. Centro de humanidades, Curso de Mestrado Acadêmico em Linguística Aplicada, UECE, Fortaleza. 
SCHERR, Rebecca. Framing human rights: comics form and the politics of recognition in Joe Sacco's Footnotes in Gaza. Textual Practice, v.29, n.1, pp. 111-131, 2015.

SIMMS, Karl. Translating sensitive texts: linguistic aspects. [Approaches to Translation Studies] Londres: Brill, Rodopi, 2006

SPIEGELMAN, Art. Os quadrinhos depois da bomba. In: NAKAZAWA, Keiji. Gen pés descalços: o recomeço. São Paulo: Conrad, 2001. p.VII-X

STAROBINAS, Marcelo. Jornalista usa os quadrinhos para relatar a guerra. Folha de S. Paulo, 29.4.2001, Ilustrada.

VOLLI, Ugo. Manual de semiótica. São Paulo: Edições Loyolas, 2007.

ZANETTIN, Federico. Comics in translation. Manchester: St. Jerome Publishing, 2008 .

\section{SÍTIOS ELETRÔNICOS CONSULTADOS}

www.aljazeera.com

www.bookreporter.com

www.bbc.co.uk

www.believermag.com

www.brasil.gov.br

www.dawn.com

www.destinodubai.com.br

www.dictionary.cambridge.org

embassies.gov.il

www.icna.org

www.internacional.estadao.com.br

www.itamaraty.gov.br

lincolnmosque.com 
www.motherjones.com

www.merriam-webster.com

$\underline{\text { www.nytimes.com }}$

www.oxforddictionaries.com

www.priberam.pt

$\underline{\text { stoa.usp.br }}$

www.super.abril.com.br

spt.wikipedia.org/wiki/Salaam_Aleikum

www.telegraph.co.uk

unrwa.org.br

www.usatoday.com

veja.abril.com.br/

www.wordreference.com 


\section{ANEXO 1}

Entrevista 1 com o tradutor Alexandre Boide

\section{O livro Notas sobre Gaza foi o primeiro livro em quadrinhos que você} traduziu?

Não. Àquela altura eu já tinha alguma experiência com outras traduções de HQs, além do anos de bagagem como editor de livros e quadrinhos na Conrad, onde trabalhei entre 2003 e 2009.

\section{Você já conhecia outras obras do autor antes de traduzi-lo?}

Sim, como trabalhava na editora que vinha lançando as obras do autor no Brasil até então, já conhecia todas as suas obras anteriores.

3. Em sua opinião, você acha que o público do texto em inglês é o mesmo do texto em português?

Acredito que haja uma coincidência perfil, o de leitores que, além dos quadrinhos, leem também textos de não-ficção e reportagens. Por outro lado, não acredito que, no Brasil, o trabalho de Joe Sacco tenha um público que vá além dos leitores já habituados a ler quadrinhos, mas não tenho nenhum elemento para comprovar isso, trata-se apenas de uma impressão pessoal

\section{Qual foi o prazo estipulado para a tradução desse livro?}

Como o autor estava cotado para vir à Flip naquele ano, foi uma tradução com prazo curto, de um mês. 


\section{Como é o processo da tradução de um romance gráfico?}

Como não se trata de um texto corrido, é preciso entregar o arquivo todo numerado, separando o texto de boxes e balões de acordo com a ordem de leitura. Exemplo:

<Página 3>

$<1>$ UM FIO DE ESPERANÇA

$<2>$ Com certeza, meu amigo Mark tinha se dado bem.

<3> VOCÊ SE DEU BEM!

$<4>$ Um trabalho bem pago de jornalista para a ONU!

\section{Quais são os aspectos da tradução de quadrinhos que o tradutor deve estar atento?}

Como existe um espaço limitado para o texto em boxes e balões, é preciso estar atento para a tradução não ficar muito maior que o texto original, pois nesse caso acaba não cabendo no espaço delimitado. Na obra de um autor como Joe Sacco, manter a concisão é fundamental.

\section{Após a tradução final, você recebe um feedback do revisor e/ou editor?}

Em geral, isso não costuma acontecer, em virtude do cronograma sempre apertado dos editores, que acabam não tendo tempo para fornecer relatórios formais aos colaboradores. Nesse caso, porém, eu tive a oportunidade de fechar o texto final, incorporando as sugestões da pessoa que fez a preparação do texto, que foi tradutora de várias obras do autor, o que naturalmente foi de grande valia. 


\section{ANEXO 2}

Entrevista 2 com o tradutor Alexandre Boide

1. Em sua opinião, você considera importante ler outros textos relacionados ao conteúdo que você vai traduzir?

Sim, é importante ter acesso à maior quantidade possível de informação sobre o tema. Nem sempre o prazo permite leituras mais aprofundadas durante o processo de trabalho, por isso é importante que o tradutor seja um leitor assíduo e atento de diversos tipos de textos.

2. Quando você encontra algum tipo de dificuldade na tradução, a quem você recorre?

Não tenho o costume de recorrer à ajuda de terceiros durante o processo de tradução. Não que eu desaconselhe a prática, é que simplesmente me acostumei a trabalhar sozinho. Naturalmente, porém, o resultado final publicado não é de forma nenhuma um trabalho individual. Existe todo um trabalho posterior, e são as mãos competentes de preparadores, editores e revisores que garantem que soluções eventualmente inadequadas serão detectadas e corrigidas. Eu faço minha parte sozinho, mas a tradução publicada é inegavelmente um trabalho coletivo.

3. Em sua opinião, no âmbito da tradução de HQ, o que é mais difícil de traduzir (humor, termos de guerra, nomes de personagens, fatos históricos...)? 
Acredito que o humor seja mais difícil, porque nem sempre existe uma tradução direta possível, principalmente no caso de trocadilhos idiomáticos. Nomes de personagens também são sempre difíceis, principalmente quando têm intenção cômica. Fatos históricos e termos técnicos exigem mais pesquisa, o que às vezes toma mais tempo. Mas pesquisar é um processo bem menos complexo e bem mais seguro do que improvisar e criar.

4. Você acredita que a tradução de HQ demanda mais criatividade, devido ao tipo de narrativa sequencial e relação imagem-texto?

Sim, acredito, exatamente pela presença da imagem, que limita a margem de adaptação possível naquele contexto, o que não ocorre com o texto não ilustrado.

\section{A oralidade fingida é recorrente em textos literários e em HQs onde há} diálogos diretos. Em sua experiência, qual é a importância dada à recriação da oralidade fingida nos textos traduzidos?

Considero fundamental, mas uma recriação exata nem sempre é possível.

Principalmente nos textos em inglês, existe uma tradição de brincar com a grafia das palavras para expressar a oralidade que vem desde os primórdios, com "Yellow Kid”, do final do século XIX, considerada por alguns a primeira HQ moderna. Em português isso não é tão comum, me parece ser uma coisa que ficou limitada ao Chico Bento, então na tradução acabamos mexendo mais com os elementos gramaticais, como concordância, colocação pronominal etc.

\section{Em Notas sobre Gaza, houve determinados momentos em que você não} sabia como traduzir certa expressão, palavra, trecho? 
Não me recordo de ter havido nenhum trecho deixado sem solução. Considero a busca por soluções parte integrante do trabalho, e não tenho o costume de deixar nada para ser resolvido posteriormente. Só sigo adiante quando o trecho tiver sido satisfatoriamente solucionado (ao menos para mim), mesmo que isso signifique algumas horas a mais de trabalho no fim do dia. Então, sim, deve ter havido momentos em que eu não sabia como traduzir certas coisas (apesar de não me lembrar de nenhum caso específico), mas no fim acabei descobrindo...

\section{Em relação ao estilo do autor, Joe Sacco, você notou alguma característica que o distinguia na HQ e que você procurou mimetizar ou recriar?}

Sim, os diálogos. No próprio posfácio do autor, ele afirma que transcreveu as falas da maneira que as recebeu do intérprete, por mais que às vezes as frases pudessem soar truncadas e incomuns aos ouvidos. Busquei manter isso ao longo do livro.

\section{No decorrer da história em Rafah e em Khan Younis há diversas referências a termos de guerra, você usou algum tipo de dicionário específico, consultou alguém que fosse especialista?}

Como se trata de um conflito contemporâneo, existe uma imensa variedade de textos de arquivos da imprensa diária que podem ser consultados sem dificuldades pela internet. Há também os textos das diferentes entidades da ONU, que muitas vezes se encontram em português. Acredito que, se fosse um texto que tratasse de um conflito mais antigo, do século XIX para trás, eu precisaria me valer de uma bibliografia mais específica. Além disso, a preparação do texto foi feita por uma pessoa que já tinha traduzido obras do autor, e ela ajudou bastante a alinhar essa 
parte de termos técnicos às traduções já consagradas. Conforme mencionei antes, a tradução publicada é sempre fruto de um trabalho coletivo.

\section{Você recebeu diretrizes de como traduzir Notas sobre Gaza?}

Não exatamente. Como na época eu tinha acabado de sair da casa que costumava lançar as obras do autor no Brasil, e havia inclusive cuidado pessoalmente da edição do álbum que até então era o mais recente (Derrotista), os editores da Companhia das Letras sabiam que eu já tinha conhecimento prévio sobre o autor e sua obra. 